Int

1.

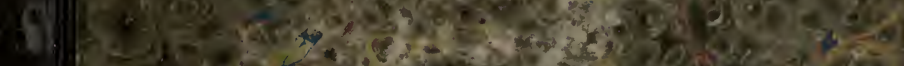

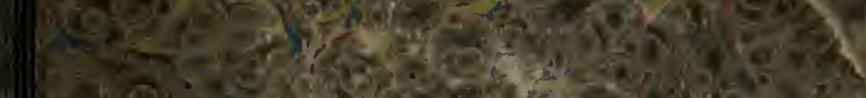

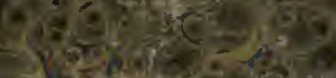

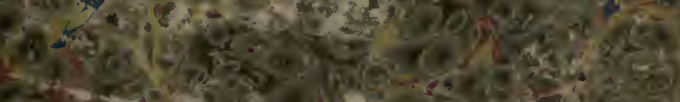

3

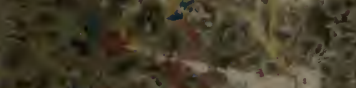

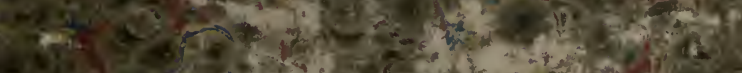

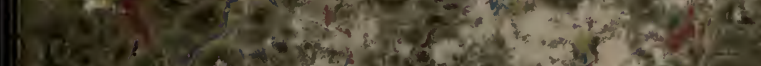

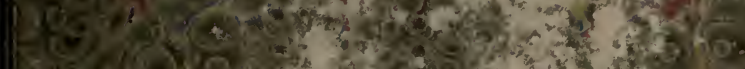

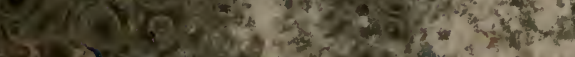

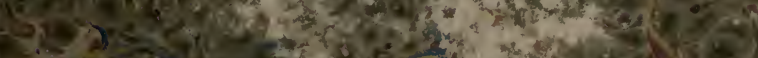

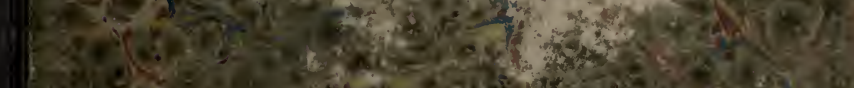

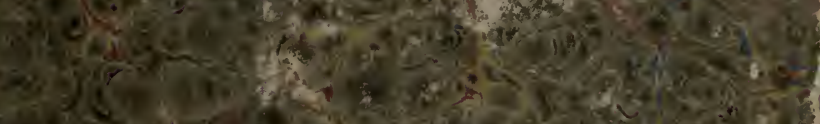
3.

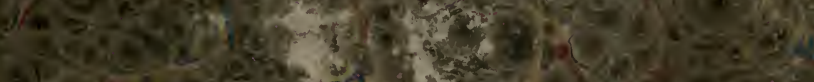
8

\title{
1)
}

t. i.

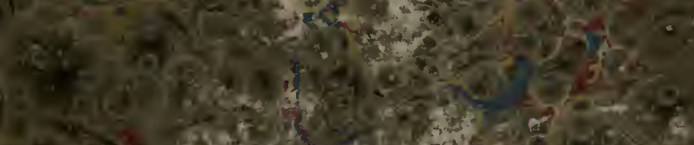

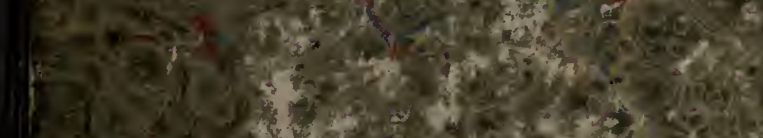

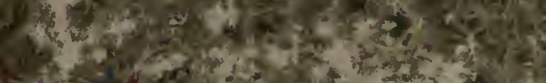

B

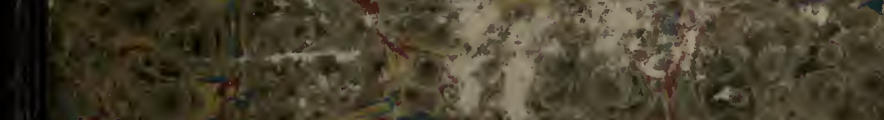

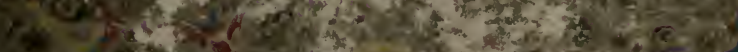

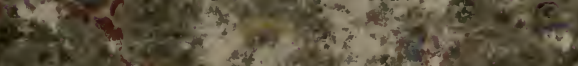
W.

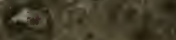

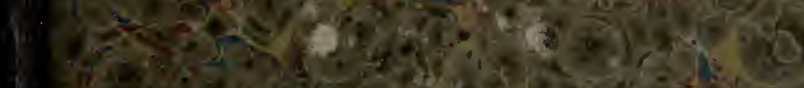

f g. 
ERKELEY
GENERAL

LIERARY

UNIVERSITY Q

CALIFORMI

Dounde tmall 1030 



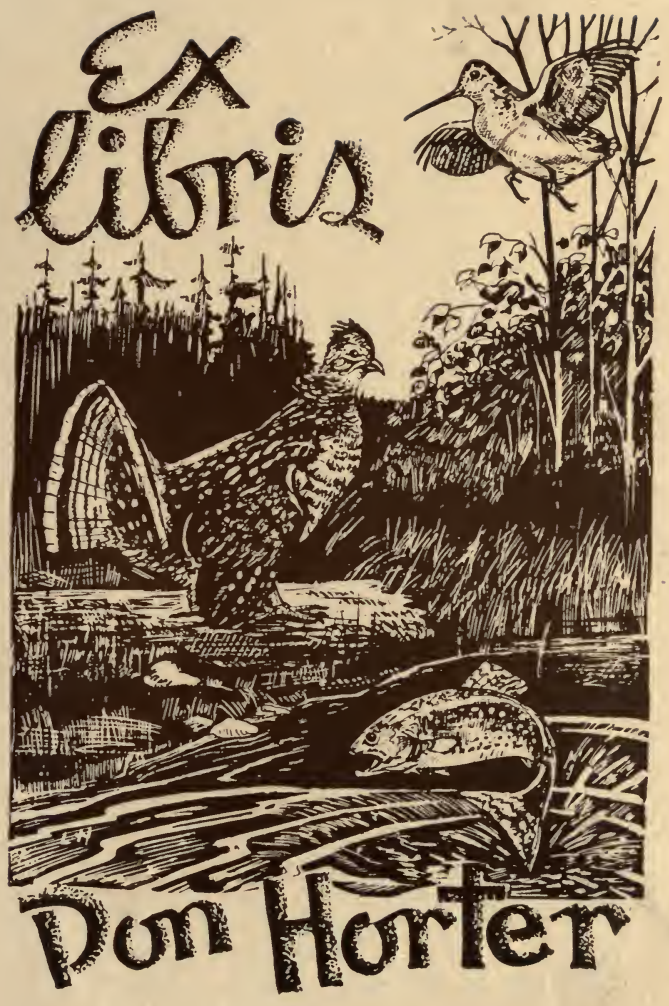


Anit Edition. scance 



\section{SALMONIA :}

\section{- or \\ DAYS OF FLY FÏHING.}

IN

A SERIES OF CONVERSATIONS.

WITH SOME

ACCOUNT OF THE HABITS

OF

FISHES BELONGING TO THE GENUS SALMO.

BY AN ANGLER.

"Equidem credo quia sit divinitus illis

Ingenium."

LONDON :

JOHN MURRAY, ALBEMARLE STREET. MDCCCXXVIII. 
L. O N D O N:

PRINTED BY C. ROWORTH, BELI. YARD, TEMPLE BAR. 


\section{$5 H 439$ \\ D 3}

TO

\section{WILLIAM BABING'TON, M.D. F.R.S.}

THESE CONVERSATIONS ARE DEDICATED,

IN REMEMBRANCE

OF SOME DELIGHTFUL DAYS PASSED IN HIS

SOCIETY,

AND IN GRATITUDE

FOR AN UNINTERRUPTED FRIENDSHIP OF

A

QUARTER OF A CENTURY. 
Digitized by the Internet Archive in 2007 with funding from Microsoft Corporation

http://www.archive.org/details/salmoniaordaysof00davyrich 


\section{P R E F A C E.}

These pages formed the occupation of the Author during many months of severe and dangerous illness, when he was wholly incapable of attending to more useful studies, or of following more serious pursuits. They formed his amusement in many hours, which otherwise would have been unoccupied and tedious; and they are published in the hope that they may possess an interest for those persons who derive pleasure from the simplest and most attainable kind of rural sports, and who practise the art, or patronize the 
objects of contemplation, of the Philosophical Angler.

The conversational manner and discursive style were chosen as best suited to the state of health of the Author, who was incapable of considerable efforts and long-continued attention; and he could not but have in mind a model, which has fully proved the utility and popularity of this method of treating the subject-The Complete Angler, by Walton and Cotton.

The characters chosen to support these Conversations, are-Halieus, who is supposed to be an accomplished fly fisher; Ornither, who is to be regarded as a gentleman generally fond of the sports of the field, though not a finished master of the art 
of angling; Poretes, who is to be considered as an enthusiastic lover of nature, and partially acquainted with the mysteries of fly fishing; and, Physicus, who is described as uninitiated as an angler, but as a person fond of inquiries in natural history and philosophy.

These characters are of course imaginary, though the sentiments attributed to them the Author may sometimes have gained from recollections of real conversations with friends, from whose society much of the happiness of his early life has been derived; and in the portrait of the mind of Halieus, given in the last dialogue, a likeness, he thinks, will not fail to be recognised to that of a most estimable Physician, ardently beloved by his friends, and esteemed and venerated by the public. 
He has limited his description of fish to the varieties of the Salmo most usual in the fresh waters of Europe, and which may be defined as a genus having eight fins, the one above the tail fleshy, and without spines.

It is to be hoped M. Cuvier's new work on fishes will supply accurate information on this " genus, which is still very imperfectly known.

LoNDON :

March 1, 1828. 


\section{SALMONIA :}

OR,

\section{DAYS OF FLY FISHING.} e.

\section{FIRST DAY.}

Halieus-Poietes-Physicus-Ornither.

INTRODUCTORY CONVERSATION-SYMPOSIAC.

Scene, London.

Phys.-Halieus, I dare say you know where this excellent trout was caught: I never ate a better fish of the kind.

HaL. - I ought to know, as it was this morning in the waters of the Wandle, not ten miles from the place where we sit, and it is through my means that you see it at table. 
Phys.-Of your own catching?

HaL. - Yes, with the artificial fly.

Phys.-I admire the fish, but I cannot admire the art by which it was taken; and I wonder how a man of your active mind and enthusiastic character can enjoy what appears to me a stupid and melancholy occupation.

HAL. - I might as well wonder in my turn, that a man of your discursive imagination and disposition to contemplation should not admire this occupation, and that you should venture to call it either stupid or melancholy.

Phys. - I have at least the authority of a great moralist, Johnson, for its folly.

HaL.-I will allow no man, however great a philosopher, or moralist, to abuse an occupation he has not tried; and as well as I remember, this same illustrious person praised the book and the character of the great Patriarch of Anglers, Isaac Walton.

Phys.--There is another celebrated man, however, who has abused this your patriarch, Lord Byron, and that in terms not very qualified. He calls him, as well as I can recol- 
lect, "A quaint old cruel coxcomb."* I must say, a practice of this great fisherman, where he recommends you to pass the hook through the body of a frog with care, as though you loved him, in order to keep him alive longer, cannot but be considered as cruel.

HaL. - I do not justify either the expression or the practice of Walton in this instance; but remember, $I$ fish only with inanimate baits, or imitations of them, and I will not exhume or expose the ashes of the dead, nor vindicate the memory of Walton, at the expense of Byron, who, like Johnson, was no fisherman: but the moral and religious habits of Walton, his simplicity of manners, and his well-spent life, exonerate him from the charge of cruelty; and the book of a coxcomb would not have been so great a favourite with most persons of re-

* From Don Juan, Canto XII. Stanza CVI.

"And Angling too, that solitary vice,

Whatever Isaac Walton sings or says:

The quaint old cruel coxcomb in his gullet

Should have a hook and a small trout to pull it."

в 2 
fined taste. A noble lady, long distinguished at court for pre-eminent beauty and grace, and whose mind possesses undying charms, has written some lines in my copy of Walton, which, if you will allow me, I will repeat to you.

Albeit, gentle Angler, I

Delight not in thy trade,

Yet in thy pages there doth lie

So much of quaint simplicity,

So much of mind,

Of such good kind,

That none need be afraid,

Caught by thy cunning bait, this book, To be ensnared on thy hook,

Gladly from thee, I'm lured to bear

With things that seemed most vile before,

For thou didst on poor subjects rear

Matter the wisest sage might hear.

And with a grace,

That doth efface

More laboured works, thy simple lore

- Can teach us that thy skilful lines,

More than the scaly brood confines. 
Our hearts and senses too, we see,

Rise quickly at thy master hand, And ready to be caught by thee Are lured to virtue willingly.

Content and peace,

With health and ease,

Walk by thy side. At thy command We bid adieu to worldly care, And joy in gifts that all may share.

Gladly, with thee, I pace along,

And of sweet fancies dream; Waiting till some inspired song, Within my memory cherished long,

Comes fairer forth, With more of worth;

Because that time upon its stream Feathers and chaff will bear away, But give to gems a brighter ray.

And though the charming and intellectual author of this poem is not an angler herself, yet I can quote the example of her lovely daughters to vindicate fly fishing from the charge of cruelty, and to prove that the most delicate and refined minds can take pleasure in this innocent amusement. One of these 
young ladies, I am told, is a most accomplished and skilful salmon fisher. And if you require a poetical authority against that of Lord Byron, I mention the philosophical and powerful poet of the lakes, and the author of

"An Orphic tale indeed,

A tale divine, of high and passionate thoughts, To their own music chaunted ;"*

who is a lover both of fly fishing and fly fishermen. Gay's poem you know, and his passionate love for the amusement, which was his principal occupation in the summer at Amesbury; and the late excellent John Tobin, author of the Honey Moon, was an ardent angler.

Phys.-I am satisfied with your poetical authorities.

HaL. - Nay, I can find authorities of all kinds, statesmen, heroes, and philosophers; I can go back to Trajan, who was fond of angling. Nelson wast a good fly fisher, and

* The Friend, page 303, by S. T. Coleridge.

+ I have known a person who fished with him at 
as a proof of his passion for it, continued the pursuit even with his left hand. Dr. Paley was ardently attached to this amusement; so much so, that when the Bishop of Durham inquired of him, when one of his most important works would be finished, he said, with great simplicity and good humour, "My Lord, I shall work steadily at it when the fly fishing season is over," as if this were a business of his life. 'And I am rather reserved in introducing living characters, or I could give a list of the highest names of Britain, belonging to modern times, in science, letters, arts, and arms, who are ornaments of this fraternity, to use the expression borrowed from the freemasonry of our forefathers.

Phys.-I do not find much difficulty in understanding why warriors, and even statesmen, fishers of men, many of whom I have known particularly fond of hunting and shoot-

Merton, in the Wandle. I hope this circumstance will be mentioned in the next edition of that most exquisite and touching Life of our Hero, by the Laureate, an immortal monument raised by Genius to Valour. 
ing, should likewise be attached to angling; but I own, I am at a loss to find reasons for a love of this pursuit amongst philosophers and poets.

HaL.-The search after food is an instinct belonging to our nature; and from the savage in his rudest and most primitive state, who destroys a piece of game, or a fish, with a club or spear, to man in the most cultivated state of society, who employs artifice, machinery, and the resources of various other animals, to secure his object, the origin of the pleasure is similar, and its object the same: but that kind of it requiring most art may be said to characterize man in his highest or intellectual state; and the fisher for salmon and trout with the fiy employs not only machinery to assist his physical powers, but applies sagacity to conquer difficulties; and the pleasure derived from ingenious resources and devices, as well as from active pursuit, belongs to this amusement. Then as to its philosophical tendency, it is a pursuit of moral discipline, requiring patience, forbearance, and command of temper. As connected 
with natural science, it may be vaunted as demanding a knowledge of the habits of a considerable tribe of created beings-fishes, and the animals that they prey upon, and an acquaintance with the signs and tokens of the weather and its changes, the nature of waters, and of the atmosphere. As to its poetical relations, it carries us into the most wild and beautiful scenery of nature; amongst the mountain lakes, and the clear and lovely streams that gush from the higher ranges of elevated hills, or that make their way through the cavities of calcareous strata: How delightful in the early spring, after the dull and tedious time of winter, when the frosts disappear and the sunshine warms the earth and waters, to wander forth by some clear stream, to see the leaf bursting from the purple bud, to scent the odours of the bank perfumed by the violet, and enamelled, as it were, with the primrose and the daisy; to wander upon the fresh turf below the shade of trees, whose bright blossoms are filled with the music of the bee; and on the surface of the waters to view the gaudy flies sparkling like 
animated gems in the sunbeams, whilst the bright and beautiful trout is watching them from below; to hear the twittering of the water-birds, who, alarmed at your approach, rapidly hide themselves beneath the flowers and leaves of the water-lily; and as the season advances, to find all these objects changed for others of the same kind, but better and brighter, till the swallow and the trout contend as it were for the gaudy May fly, and till in pursuing your amusement in the calm and balmy evening, you are serenaded by the songs of the cheerful thrush and melodious nightingale, performing the offices of paternal love, in thickets ornamented with the rose and woodbine.

Prys.-All these enjoyments might be obtained without the necessity of torturing and destroying an unfortunate animal, that the true lover of nature would wish to see happy in a scene of loveliness.

HaL.-If all men were Pythagoreans and professed the Brahmin's creed, it would undoubtedly be cruel to destroy any form of animated life; but if fish are to be eaten, I 
FISH POSSESSED OF LitTLE SENSIBILITY. 11

see no more harm in capturing them by skill and ingenuity with an artificial fly, than in pulling them out of the water by main force with the net; and in general when taken by the common fishermen, fish are permitted to die slowly, and to suffer in the air, from the want of their natural element; whereas, every good angler, as soon as his fish is landed, either destroys his life immediately, if he is wanted for food, or returns him into the water.

Phys.-But do you think nothing of the torture of the hook, and the fear of capture, and the misery of struggling against the powerful rod?

HAL. - I have already admitted the danger of analysing, too closely, the moral character of any of our field sports; yet $I$ think it cannot be doubted that the nervous system of fish, and cold blooded animals in general, is less sensitive than that of warm blooded animals. The hook usually is fixed in the cartilaginous part of the mouth, where there are no nerves; and a proof that the sufferings of a hooked fish cannot be great is found in 
the circumstance, that though a trout has been hooked and played for some minutes, he will often, after his escape with the artificial fly in his mouth, take the natural fly, and feed as if nothing had happened; having apparently learnt only from the experiment, that the artificial fly is not proper for food. And I have caught pikes with four or five hooks in their mouths, and tackle which they had broken only a few minutes before; and the hooks seemed to have had no other effect than that of serving as a sort of sauce piquante, urging them to seize another morsel of the same kind.

Phys.-Fishes are mute, and cannot plead, even in the way that birds and quadrupeds do, their own cause; yet the instances you quote only prove the intense character of their appetites, which seem not so moderate as Whiston imagined, in his strange philosophical romance on the Deluge; in which he supposes, that in the antediluvian world the heat was much greater than in this, and that all terrestrial and aerial animals had their passions so exalted by this high tem- 
perature, that they were lost in sin, and destroyed for their crimes; but that fish, living in a cooler element, were more correct in their lives, and were therefore spared from the destruction of the primitive world. You have proved, by your examples, the intensity of the appetite of hunger in fishes; Spalanzani has given us another proof of the violence of a different appetite, or instinct, in a cold-blooded animal, that has most of the habits of the genus-the frog; which, in the breeding season, remains attached to the female, though a limb, or even his head, is removed from the body.

HAL. - This is likewise in favour of my argument, that the sensibility of this class of animals to physical pain is comparatively small.

Phys.-The advocates for a favourite pursuit never want sophisms to defend it. I have even heard it asserted, that a hare enjoys being hunted. Yet I will allow that fly fishing, after your vindication, appears amongst the least cruel of field sports;-I can go no farther; as I have never thought 
of trying it, I can say nothing of its agreeableness as an amusement, compared with hunting and shooting.

HaL. - I wish that you would allow me to convince you, that for a contemplative man, as you are, and a lover of nature, it is far superior, more tranquil, more philosophical, and, after the period of early youth, more fitted for a moderately active body and mind, requiring less violent exertion; and, pursued in moderation, affording an exercise conducive to health. There is a river, only a few miles off, where I am sure I could obtain permission for you, and our friend Poietes, to fish.

Phys.-I am open to conviction on all subjects, and have no objection to spend one May day with you in this idle occupation; premising, that you take at least one other companion, who really loves fishing.

HaL.-You, who are so fond of natural history, even should you not be amused by fishing, will, I am sure, find objects of interest on the banks of the river.

Phys.-I fear I am not entomologist 
FIELD SPORTS RELATED TO NAT. HIST. 15

enough to follow the life of the May-fly, but I shall willingly have my attention directed to its habits. Indeed, I have often regretted that sportsmen were not fonder of zoology; they have so many opportunities, which other persons do not possess, of illustrating the origin and qualities of some of the most curious forms of animated nature; the causes and character of the migrations of animals; their relations to each other, and their place and order in the general scheme of the universe. It has always appeared to me, that the two great sources of change of place of animals, was the providing of food for themselves, and resting places and food for their young. The great supposed migrations of herrings from the poles to the temperate zone, have appeared to me to be only the approach of successive shoals from deep to shallow water, for the purpose of spawning. The migrations of salmon and trout are evidently for the purpose of depositing their ova, or of finding food after they have spawned. Swallows, and bee-eaters, decidedly pursue flies over half a continent; the scolo- 
, pax or snipe tribe, in like manner, search for worms and larvæ,-flying from those countries where either frost or dryness prevents them from boring,-making generally small flights at a time, and resting on their travels where they find food. And a journey from England to Africa, is no more for an animal that can fly, with the wind, one hundred miles in an hour, than a journey for a Londoner to his seat in a distant province. And the migrations of smaller fishes or birds always occasions the migration of larger ones, that prey on them. Thus, the seal follows the salmon, in summer, to the mouths of rivers; the hake follows the herring and pilchard; hawks are seen in great quantities, in the month of May, coming into the east of Europe, after quails and landrails; and locusts are followed by numerous birds, that, fortunately for the agriculturist, make them their prey.

HaL.- It is not possible to follow the amusement of angling, without often having your attention directed to the modes of life of fishes, insects, and birds, and many cu- 
rious and interesting facts, as it were, forced upon your observation. I consider you, (Physicus,) as pledged to make one of our fishing party; and I hope, in a few days, to give you an invitation to meet a few worthy friends on the banks of the Colne. And you, (Poietes,) who, I know, are an initiated disciple of Walton's school, will, I trust, join us. We will endeavour to secure a fine day; two hours, in a light carriage with good horses, will carry us to our ground; and I think I can promise you green meadows, shady trees, the song of the nightingale, and a full and clear river.

Poiet.-This last is, in my opinion, the most poetical object in nature. I will not fail to obey your summons. Pliny has, as well as I recollect, compared a river to human life. I have never read the passage in his works, but I have been a hundred times struck with the analogy, particularly amidst mountain scenery. The river, small and clear in its origin, gushes forth from rocks, falls into deep glens, and wantons and meanders through a wild and picturesque 
country, nourishing only the uncultivated tree or flower by its dew or spray. In this, its state of infancy and youth, it may be compared to the human mind in which fancy and strength of imagination are predominantit is more beautiful than useful. When the different rills or torrents join, and descend into the plain, it becomes slow and stately in its motions ; it is applied to move machinery, to irrigate meadows, and to bear upon its bosom the stately barge; -in this mature state, it is deep, strong, and useful. As it flows on towards the sea, it loses its force and its motion, and at last, as it were, becomes lost and mingled with the mighty abyss of waters.

HaL.-One might pursue the metaphor still further, and say, that in its origin-its thundering and foam, when it carries down clay from the bank, and becomes impure, it resembles the youthful mind, affected by dangerous passions. And the influence of a lake, in calming and clearing the turbid water, may be compared to the effect of reason in more mature life, when the calm, 
A River the EMblem of human Life. 19

deep, cool and unimpassioned mind is freed from its fever, its troubles, bubbles, noise and foam. And, above all, the sources of a river,-which may be considered as belonging to the atmosphere,-and its termination in the ocean, may be regarded as imaging the divine origin of the human mind, and its being ultimately returned to, and lost in, the Infinite and Eternal Intelligence from which it originally sprung. 


\section{SECOND DAY.}

\section{Halieus-Poretes-Ornither- \\ Physicus.}

'TROUT FISHING.-DENHAM, MAY, 1810.

\section{Morning.}

HaL.-I am delighted to see you, my worthy friends, on the banks of the Colne; and am happy to be able to say, that my excellent host has not only made you free of the river for this day's angling, but insists upon your dining with him,--wishes you to try the evening fishing, and the fishing to-morrow morning, - and proposes to you, in short, to give up twenty-four hours to the delights of an angler's May-day.

Poret.-We are deeply indebted to him; and I hardly know how we can accept his offer, without laying ourselves under too great an obligation. 
HAL. - Fear not: he is as noble minded a man as ever delighted in good offices; and so benevolent, that I am sure he will be almost as happy in knowing you are amused, as you can be in your sport; and he hopes for an additional satisfaction in the pleasure of your conversation.

\section{Poiet.-So let it be.}

H.AL. - I will take you to the house; you shall make your bow, and then you will be all free to follow your own fancies. Remember, the dinner hour is five; the dressing bell rings at half-past four; be punctual to this engagement, from which you will be free at seven.

Poiet.-This is really a very charming villa scene, I may almost say, a pastoral scene. The meadows have the verdure which even the Londoners enjoy as a peculiar feature of the English landscape. The river is clear, and has all the beauties of a trout stream of the larger size,-there rapid, and here still, and there tumbling in foam and fury over abrupt dams upon clean gravel, as if pursuing a natural course. And 
that island with its poplars and willows, and the flies making it their summer paradise, and its little fishing house, are all in character; and if not extremely picturesque, it is at least a very pleasant scene, from its verdure and pure waters, for the lovers of our innocent amusement.

HAL.-It is ten o'clock: you may put up your rods, or take rods from the hall; for so hospitable is the master of this mansion, that every thing is supplied to our hands. And Physicus, as you are the only one of our party ignorant of the art of fly fishing, I will fit you with a rod and flies; and let me advise you to begin with a line shorter than your rod, and throw at first slowly and without effort, and imitate us as well as you can. As for precepts, they are of little value, practice and imitation will make you an angler.

Poiet.-I shall put together my rod, and fish with my own flies. It may be fancy, but I always think I do best with tackle with which I am used to fish.

HaL.-You are right; for fancy is al- 
ways something: and when we believe that we can do things better in a particular way, we really do, by the influence of imagination, perform them both better and with less effort. I agree with moralists, that the standard of virtue should be placed higher than any one can reach; for in trying to rise, man will attain a more excellent state of being than if no effort were made. But to our business. As far as the perfection of the material for the angler is concerned, the flies you find on this table are as good as can be made, and for this season of the year, there is no great variety in this river. We have had lately some warm days, and though it is but the 18th of May, yet I know the May fly has been out for three or four days, and this is the best period of this destructive season for the fisherman. There are, I observe, many male flies on the high trees, and some females on the alders.

Phys.-But I see flies already on the water, which seem of various colours, brown and grey, and some very pale,-and the trout appear to rise at them eagerly. 
HaL. - The fly you see is called by fishermen the alder fly, and is generally in large quantities before the May fly. Imitations of this fly, and of the green and the grey drake of different shades, are the only ones you will need this morning, though I doubt if the last can be much used; as the grey drake is not yet on the water in any quantity.

Phys.- Pray can you give us any account of these curious little animals?

HaL. - We ought to draw upon your stores of science for information on these subjects.

Phys.-I really know nothing of Entomology, but I am desirous of acquiring knowledge.

HAL. - I have made few observations on flies as a philosophical naturalist. What I know I will state, but at another time. But see, the green drake is descending upon the water, and some are leaving the alders to sport in the sunshine, and to enjoy the pleasures of their brilliant, though short existence; and their life, naturally ephemeral, is made one of scarcely a moment, by the fishes 
and birds: that which the swallow or the duck spares is caught by the fish. The fly is new, and in the imitation, I recommend the olive tint, or what the Irish call, the green monkey. That is, an artificial fly, with a wing of dyed yellow drake's feather, a body of yellow monkey's fur, and a small quantity of olive mohair for legs. For myself, I shall fish for some time with a large red alder fly, and I dare say, with as much success. That is, with a fly with a dark peacock's harle for body, a red hackle for legs, and wings of the landrail below, and starling above.

Point.-The water is quite in motion: what noble fish I see on the feed! I never beheld a finer sight, though I have often seen the May fly on well stocked waters.

HaL.-This river is most strictly preserved; not a fish has been killed here since last August, and this is the moment when the large fish come to the surface, and leave their cad bait search and minnow hunting. But I have hardly time to talk; I have hold of a good fish: they take either alder or May fly, and having never been fished 
for this year, they make no distinction, and greedily seize any small object in motion on the water. You see the alder fly is quite as successful as the May fly; but there is a fish which has refused it, and because he has been feeding, glutton like, on the May fly: that is the fifth he has swallowed in a minute. Now I shall throw the drake a foot above him. It floats down, and he has taken it. A fine fish; I think at least $4 \mathrm{lbs}$. This is the largest fish we have yet seen, but in the deep water still lower down, there are larger fish. One of 5lbs. I have known taken here, and once a fish a little short only of $6 \mathrm{lbs}$.

Poiet.-I have just landed a fish which I suppose you will consider as a small one; yet I am tempted to kill him.

HaL.-He is not a fish to kill, throw him back, he is much under $2 \mathrm{lbs}$. and, as I ought to have told you before, we are not allowed to kill any fish of less size; and I am sure we-shall all have more than we ought to carry away even of this size. Pray put him into the well, or rather give him to the fisherman to turn back into the water. 
Poret.-I cannot sáy I approve of this manner of fishing: I lose my labour.

HaL. - As the object of your fishing, I hope, is innocent amusement, you can enjoy this, and show your skill in catching the animal; and if every fish that took the May fly were to be killed, there would be an end to the sport in the river, for none would remain for next year.

Phys.-The number of flies seems to increase as the day advances; and I never saw a more animated water scene: all nature seems alive; even the water-wagtails have joined the attack upon these helpless and lovely creations from the waters.

HAL.-It is now one o'clock; and between twelve and three is the time when the May fly rises with most vigour. It is a very warm day, and with such a quantity of fly, every fish in the river will probably be soon feeding. See, below the wear, there are two or three large trout lately come out; and from the quiet way in which they swallow their prey, and from the size of the tranquil undulation that follows their rise, I suspect 
they are the giants of this river. Try if you cannot reach them: one is near the bank in a convenient place for a throw, for the water is sufficiently rough to hide the deception, and these large fish do not take the fly well in calm water, though with natural flies on the hook they might all be raised.

Poiet.-I have him! Alas! he has broken me, and carried away half my bottom line. He must have been a fish of 7 or $8 \mathrm{lbs}$. What a dash he made! He carried off my fly by main force.

HaL. - You should have allowed your reel to play and your line to run: you held him too tight.

Poiet.-He was too powerful a fish for my tackle; and even if I had done so, would probably have broken me by running amongst the weeds.

HaL. - Let me tell you, my friend, you should never allow a fish to run to the weeds, or to strike across the stream; you should carry him always down stream, keeping his head high, and in the current. If in a weedy river you allow a large fish to run up 
stream, you are almost sure to lose him. There, I have hooked the companion of your lost fish, on the other side of the stream,-a powerful creature: he tries, you see, to make way to the weeds, but I hold him tight.

Poiet.-I see you are obliged to run with him, and have carried him safely through the weeds.

$\mathrm{H}_{\mathrm{AL}}$. - I have him now in the rapids on the shallow, and I have no fear of losing him, unless he strikes the hook out of his mouth.

Poiet.-He springs again and again.

HaL.-He is off; in one of these somersets he detached the steel, and he now leaps to celebrate his escape. We will leave this place, where there are more great fish, and return to it after a while, when the alarm produced by our operations has subsided.

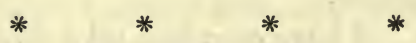

It is now a quarter of an hour since we left the large pool: let us return to it; I see the fish are again rising. 
PoIEt.-I am astonished! It appears to me that the very same fish are again feeding. There are two fish rising nearly in the same spot where they rose before: can they be the same fish?

HAL.-It is very possible. It is not likely that three other fish of that size should occupy the same haunts.

Poiet.-But I thought after a fish had been hooked, he remained sick and sulky for some time, feeling his wounds uncomfortable.

HAL. - The fish that I hooked is not rising in the same place, and therefore, probably was hurt by the hook; but one of these fish seems to be the same that carried off your fly, and it is probable that the hook only struck him in a part of the mouth where there are no nerves; and that he suffered little at the moment, and does not now feel his annoyance.

Poiet.-I have seen him take four or five flies: I shall throw over him. There, he rose, but refused the fly. He has at least learnt from the experiment he has made, 
to distinguish the natural from the artificial fly.

HAL. - This, I think, always happens after a fish has been hooked with an artificial fly. $\mathrm{He}$ becomes cautious, and is seldom caught that year, at least with the same means in the same pool: but I dare say that fish might be taken with a natural fly; or, what is better, two upon the hook.

Poiet.-Pray try him.

HAL. - I am no great artist at this kind of angling, but I will for once try my fortune, though it is hardly fair play; and it is rather to endeavour to recover your tackle, than for the sake of the fish; for this method I seldom practise, and never encourage.

Poiet. - Pray make no apologies for the trial. Such a fish-certainly a monster, for this river-should be caught, by fair means, if possible, but caught, by any means.

HAL.-You lost that fish, and you overrate his size, as you will see, if I have good fortune. I put niy live flies on the hook with some regret and some disgust. I will not employ another person to be my minister 
of cruelty, as I remember a lady of fashion once did, who was very fond of fishing for perch, and who employed her daughter, a little girl of nine years of age, to pass the hook through the body of the worm! Now there is a good wind, and the fish has just taken a natural fly. I shall drop the flies, if possible, within a few inches of his nose. He has risen. He is caught! I must carry him down stream to avoid the bed of weeds above. I now have him on fair ground, and he fights with vigour. Fortunately, my silk --worm gut is very strong, for he is not a fish to be trifled with. He begins to be tired; prepare the net. We have him safe, and see your link hangs to his lower jaw : the hook had struck the cartilage on the outside of the bow, and the fly, probably, was scarcely felt by him.

Phys.-I am surprised! That fish evidently had discovered that the artificial fly was a dangerous bait, yet he took the natural fly which was on a hook, and when the silk worm gut must have been visible. 
HaL.-I do not think he saw either the gut or the hook. In very bright weather and water, I have known very shy fish refuse even a hook baited with the natural fly, scared probably by some appearance of hook or gut. The vision of fishes when the surface is not ruffled is sufficiently keen. I have seen them rise at gnats so small as to be scarcely visible to my eye.

Phys.-You just now said, that a fish pricked by the hook of an artificial fly would not usually take it again that season.

HaL.-I cannot be exact on that point: I have known a fish that I have pricked retain his station in the river, and refuse the artificial fly, day after day, for weeks together; but his memory may have been kept awake by this practice, and the recollection seems local and associated with surrounding objects; and if a pricked trout is chased into another pool, he will, I believe, soon again take the artificial fly. Or if the objects around him are changed, as in Autumn, by the decay of weeds, or by their being cut, 
the same thing happens; and a flood, or a rough wind, I believe, assists the fly fisher, not merely by obscuring the vision of the fish, but, in a river much fished, by changing the appearance of their haunts: large trouts almost always occupy particular stations, under, or close to, a large stone or tree; and, probably, most of their recollected sensations are connected with this dwelling.

Phys.-I think I understand you, that the memory of the danger and pain does not last long, unless there is a permanent sensation with which it can remain associated,such as the station of the trout; and that the recollection of the mere form of the artificial fly, without this association, is evanescent.

OrN.-You are diving into metaphysics; yet I think, in fowling, I have observed that the memory of birds is local. A woodcock, that has been much shot at and scared in a particular wood, runs to the side where he has usually escaped, the moment he hears the dogs; but if driven into a new wood, he 
seems to lose his acquired habits of caution, and becomes stupid.

Poiet.-This great fish, that you have just caught, must be nearly of the weight I assigned to him.

HAL.-O no; he is, I think, above 5lbs. but not 6 lbs.; but we can form a more correct opinion by measuring him, which I can easily do, the but of my rod being a measure. He measures, from nose to fork, a very little less than twenty-four inches, and, consequently, upon the scale which is appropriate to well-fed trouts, should weigh 5 lbs. $10 \mathrm{oz}$. - which, within an ounce, I doubt not, is his weight.

Phys.-O, I see you take the mathematical law, that similar solids are to each other in the triplicate ratio of one of their dimensions.

HaL. - You are right.

Phys.-But I think you are below the mark, for this appears to me an extraordinarily thick fish. 
TROUT FROM THE COLNE.

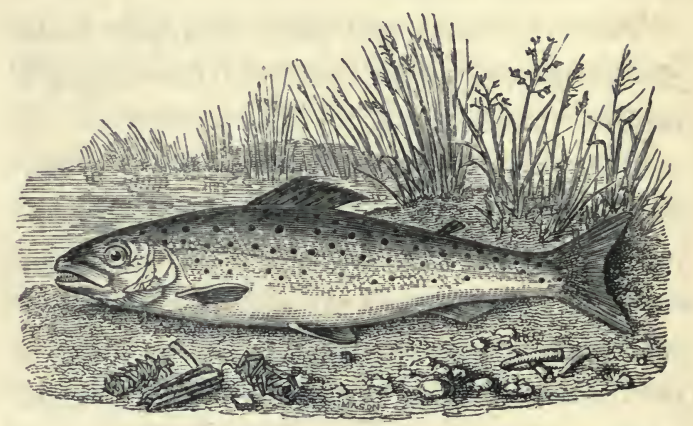

HAL.-He is a clean fish, but, in proportion, not so thick as my model, which was a fish of 17 inches by 9 inches, and weighed 2lbs.-this is my standard solid. We will try him. Ho! Mrs. B.!-bring your scales, and weigh this fish. There, you see, he weighs 5 lbs. $10 \frac{1}{2} \mathrm{oz}$.

Phys.-Well, I am pleased to see this fish, and amused with your sport; but though I have been imitating you in throwing the fly, as well as I can, yet not a trout has taken notice of my fly, and they seem scared by my appearance. 
HaL.-Let me see you perform. There are two good trout taking flies opposite that bank, which you can reach. You threw too much line into the water, and scared them both; but I will take you to the rapid of the Tumbling Bay, where the river falls ; there the quickness of the stream will prevent your line from falling deep, and the foam will conceal your person from the view of the fish. And let me advise you to fish only in the rapids, till you have gained some experience in throwing the fly. There are several fish rising in that stream.

Phys.-I have raised one, but he refused my fly.

HaL. - Now you have a fish.

Phys. - I am delighted;-but he is a small one.

HAL.-Unluckily, it is a dace.

Phys.-I have now a larger fish, which has pulled my line out.

HAL. - Give him time. That is a good trout. Now wind up; he is tired, and your own. I will land him. He is a fish to keep, being above $2 \mathrm{lbs}$. 
Phys,-I am well pleased.

$\mathrm{H}_{\mathrm{AL}}$. - There are many larger trouts here; go on fishing, and you will hook some of them. And when you are tired of this - rapid, you will find another a quarter of a mile below. And continue to fish with a short line, and drop your fly, or let it be carried by the wind on the water, as lightly as possible. Well, Poietes, what success?

Poiet.-I have been fishing in the stream above; but the flies are so abundant, that the large fish will not take my artificial fly, and I have caught only three fish, all of which the fisherman has thrown into the water, though I am sure one of them was more than 2 lbs.

HaL.-You may trust his knowledge: with a new angler, our keeper would be apt rather to favour the fisherman than the fish. But we will have all fish you wish to be killed, and above $2 \mathrm{lbs}$., put into the well of the boat, where they can be examined, and, if you desire, weighed and measured, and such kept as are worth keeping. No good angler should kill a fish, if possible, till he is 
needed to be crimped; for the sooner he is dressed after this operation, the better;and I assure you, a well-fed trout of the Colne, crimped and cooled ten minutes before he is wanted for the kettle or the gridiron, is a fish little inferior to the best salmon of the best rivers. It is now nearly two o'clock, and there is a cloud over the sun; the fly is becoming less abundant; you are now likely, Poietes, to have better sport. Try in that deep pool, below the Tumbling Bay; I see two or three good fish rising there, and there is a lively breeze. The largest fish refuses your fly again and again; try the others. There, you have hooked him; now carry him down stream, and keep his head high, out of the weeds. He plunges and fights with great force; --he is the best-fed fish I have yet seen at the end of the line, and will weigh more, in proportion to his length. I will land him for you. There he is,-and measures 19 inches; and I dare say his weight is not much short of $3 \mathrm{lbs}$. We will preserve him in the well. 
Poiet.-He has hardly any spots, and is silvery all over; and the whole of the lower part of his body is beautifully clean.

HaL.-He is likewise broad backed; and you may observe his few spots are black, and these are very small. I have always observed, in this river, that the nearer the fish approach to perfection, the colour of the body becomes more uniform,-pale olive above, and bright silver below; and these qualities are always connected with a small head,-or rather, an oval body, and deepred flesh.

Poiet.-May not the red spots be marks of disease-a hectic kind of beauty? For I observed in a very thin and poor fish, and great-headed, that I caught an hour ago, which had leeches sticking to it, a number of red spots, and a long black back, and black or bluish marks even on the belly.

$\mathrm{H}_{\mathrm{AL}}$. - I do not think red spots a symptom of disease; for I have seen fish in other rivers, and even small fish in this river, in perfectly good season, with red spots; 


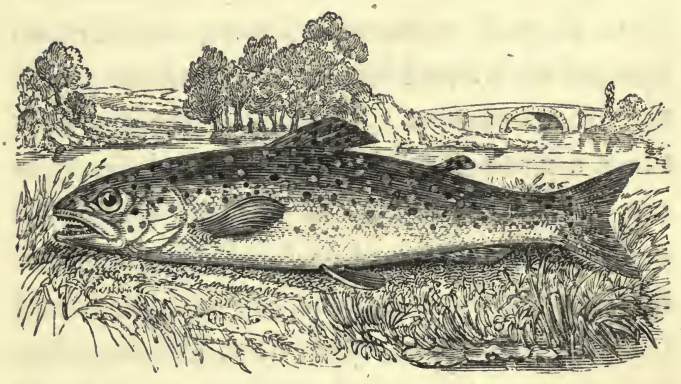

but the colours of fish are very capricious, and depend upon causes which cannot be easily defined. I have known fish, from some lakes in Ireland, mottled in a most singular way, - their colour being like that of the tortoise: the nature of the water, exposure to the light, and probably their kind of food, produce these effects. I think it possible, when trout feed much on hard substances-such as shell-fish and the ova of other fish-they liave more red spots, and redder fins. This is the case with the gillaroo and the char, who feed in this manner; 
and the trout, that have similar habits, might be expected to resemble them. When trout feed most on small fish, as minnows, and on flies, they have more tendency to become spotted with small black spots, and are generally more silvery. The Colne trout are, in their advanced state, of this kind; and so are the trout, called in Ireland buddocks and dolochans, found in Loch Neah. Particular character becomes hereditary, and the effects of a peculiar food influence the appearance of the next generation. I hope, Ornither, you have had good sport.

Orn.-Excellent! Since you left me, below the wear, I have hooked at least fifteen or twenty good fish, and landed and saved eight above 2lbs.; but I have taken no fish like the great one which you caught by poaching with the natural flies. The trout rose wonderfully well within the last quarter of an hour, but they are now all still; and the river, which was in such active motion, is now perfectly quiet, and seems asleep and almost dead.

HaL. - It is past four o'clock, and some 
dark, heavy clouds are come on,- the fly is off. It is almost the hour for the signal of the dressing bell; and there is nothing more to be done now till evening. But see! our host is come to examine our fish in the well, and to inquire about our sport; and, I dare say, will order some of our fish to be dressed for the table.

Host.-I hope, gentlemen, you have been amused?

HaL.-Most highly, sir. As a proof of it, there are in the fish-well eighteen good trout,-and one not much short of $6 \mathrm{lbs}$.; three above $4 \mathrm{lbs}$., and four above 3 lbs. in weight. I hope you will order that great fish for your dinner.

Host.-We will see. He is a fine fish, and fit for a present, even for a Prince-and you shall take him to a Prince. Here is a fish, and there another, of the two next sizes, which I am sure will cut red. Prepare them, fisherman. And, Halieus, you shall catch two or three perch, for another dish; I know there are some good ones below the piles of the wear; I saw them hunt- 
ing small fish there yesterday morning. Some minnows, ho!- and the perch rods!

HAL. - I am tired, sir, and would willingly avoid minnow fishing after such a morning's sport.

Host.-Come, then, I will be a fisher for the table. I have one-and another, that will weigh nearly a pound a piece. Now, there is a cunning perch that has stolen my minnow; I know he is a large one. He has robbed me again and again; and if I fish on in this way, with the hook through the upper lip, will, I dare say, carry away all the minnows in the kettle. I shall put on a strong small hook, on' a stout, though fine, gut, with slender wire round the top, and pass the hook through the back fin of the minnow, and try my sagacity against his. Lo! I have him!-and a very strong fish he is, and gone to the bottom; but even though the greatest perch in the river, he cannot bite the gut,- - he will soon be tired and taken. He- now comes up, and is landed. He must be above 3 lbs. - a magnificent perch! Kill him and crimp him, fisherman; 
take our two trout, and the three perch, to the kitchen, and let them be dressed as usual. You shall have a good dish of fish, worthy of such determined anglers. But.I see one of your party coming up by the side of the river, who seems tired and out of spirits.

HaL. - It is Physicus, who has this day commenced his career as a fly fisher; and who, I dare say, has been as successful as the uninitiated generally are. I hope you have followed my advice and been successful?

Prys.-I caught two trout in the rapid where you left me; but they were small, and the fisherman threw them in. Below the wear, in the quick stream, I caught two dace, and what astonished me very much, a perch, which you see here, and which I thought never took the fly.

HaL.-O yes, sometimes; and particularly when it is below the surface: and what more?

Phys.-By creeping on my knees, and dropping my fly over the bank, I hooked a very large fish which I saw rising, and 
which was like a salmon; but he was too strong for my tackle, ran out all my line, and at last broke off by entangling my link in a post in the river. I have been very unlucky! I am sure that fish was larger than the great one you took with the natural fly.

HaL.-Come, you have been initiated, and I see begin to take an interest in the sport, and I do not despair of your becoming a distinguished angler.

Phys.-With time and some patience: but I am sorry I tortured that poor fish without taking him.

HAL.-I dare say you are.

(They go to dinner.)

* $\quad * \quad * \quad *$

(They return from the house.)

EVENING.

HaL.-You have, I am sure, Gentlemen, dined well; no one ever dined otherwise in this house. It is a beautiful calm evening, and many fish might be caught where we 
fished in the morning; but I will take you to another part of the river; you shall each catch a fish, and then we will give over; for the evenings sport should be kept till a late season,-July or August,-when there is little fly on in the day time: and it would be spoiling the diversion of our host, to catch or prick all the fish in the upper water; and with a gentleman so truly liberal, and so profuse of his means of giving pleasure to others, no improper liberties should be taken. I shall not fish myself, but shall have my pleasure in witnessing your sport. It must be in a boat, and you must steal slowly up the calm water, and glide like aerial beings on the surface, making no motion in the water, and showing no shadow. Your fly must be an orange or brown palmer with a yellow body; for the grey drake is not yet on the water. The fish here are large, and the river weedy, so you must take care of your fish and your tackle.

Poret.-We have at least passed over halfa-mile of water, and have seen no fish rise; yet there is a yellowish or reddish fly in the 
air, which moves like a drake; and there are clouds of pale brown flies encircling the alders. Now I think I see a large trout rise below that alder.

HAL.-That is not a trout, for he rises in a different place now, and is probably a large roach or chub; do not waste your time upon him. You may always know a large trout when feeding in the evening. He rises continuously, or at small intervals, -in a still water almost always in the same place,and makes little noise,-barely elevating his mouth to suck in the fly, and sometimes showing his back fin and tail. A large circle spreads around him, but there are seldom any bubbles when he breaks the water, which usually indicate the coarser fish: we will wait a few minutes; I know there must be trout here and the sun is setting, and the yellow fly, or dun cut, coming on the water. See, beneath that alder is a trout rising, and now there is another thirty yards higher up. Take care, get your line out in another part of the water, and in order, for reaching the fish, and do not throw till you are sure you 
can reach the spot, and throw at least halfa-yard above the fish.

ORn.-He rose, I suppose, at a natural fly, the moment before my fly touched the water.

HaL.-Try again. You have hooked him, and you have done well not to strike when he rose. Now hold him tight, wind up your line, and carry him down the stream. Push the boat down stream, fisherman. Keep your fish's head up. He begins to tire,and there is landed. A fine well-fed fish, not much less than 4lbs. Throw him into the well. Now, Poietes, try that fish rising above, -and there are two more.

Pore'r.-I have him!

HaL. - Take care. He has turned you, and you have suffered him to run out your line, and he is gone into the weeds under the willow: let him fall down stream.

Poret.-I cannot get him out.

HaL. - Then wind up. I fear he is lost, yet we will try to recover him by taking the boat up. The line is loose: he has left the link entangled in the weeds, and carried 
your fly with him. He must have been a large fish, or he could not have disentangled himself from so strong a gut. Try again, there are fish now rising above and below; where the water is in motion, opposite that willow, there are two fish rising.

Poiet.-I have one of them.

HaL. - Now you are doing well. Down with the boat, and drag your fish downwards. Continue to do so, as there are weeds all round you. You can master him now; keep him high, and he is your own. Put the net under him, and bring him into the boat; he is a well fed fish, but not of the proper size for a victim: about 2lbs. - Now, Physicus, try your fortune with the fish above that rises so merrily still. You have him! Now use him as Poietes did the last. Very well; I see he is a large fish,-take your time. He is landed; a fish nearly of $3 \mathrm{lbs}$. and in excellent season.

Phys.-An che Io son Piscatore-I am too a fisherman-a triumph.

HaL. - Now we have finished our fishing, and must return to the light supper of our 
host. It would be easy now, and between this hour and ten, to take half-a-dozen large fish in this part of the water; but for the reason I have already stated, it would be improper.

Poiet.-Pray would not this be a good part of the water for day fishing.

HAL.-Undoubtedly, a skilful angler might take fish here in the day; but the bank is shaded by trees, there is seldom any sensible wind on the water, and the apparatus and the boat in motion are easily perceived in the daylight; and the water is so deep, that a great quantity of fly is necessary to call up the fish; and in general there is a larger quantity of fly in hot summer evenings, than even in the brightest sunshine.

Phys.-The fly appears to me like a moth that is now on the water.

HAL. - It is.

Poiet. - What flies come on late in the season here?

$\mathrm{H}_{\mathrm{AL}}$.- Flies of the same species; some darker, and some with a deeper shade of red; and there are likewise the true moths, 
the brown and white, which, in June and July, are seized with avidity by the fish; and being large flies, take large fish.

OrN.-Surely the May fly season is not the only season for day fishing in this river?

HaL.-Certainly not. There are as many fish to be taken perhaps in the Spring fishing; but in this deep river they are seldom in good season till the May fly has been on, and a fortnight hence they will be still better than even now. In September there may be good fish taken here; but the autumnal flies are less plentiful in this river than the spring flies.

Phys.-Pray tell me what are the species of fly which take in these two seasons.

HaL.-You know that trout spawn or deposit their ova and seminal fluid in the end of the autumn or beginning of winter, from the middle of November till the beginning of January, their maturity depending upon the temperature of the season, their quantity of food, \&c. For some time (a month or six weeks) before they are prepared for the sexual function, or that of re- 
production, they become less fat, particularly the females; the large quantity of eggs and their size probably affecting the health of the animal, and compressing generally the vital organs in the abdomen. They are at least six weeks or two months after they have spawned before they recover their flesh: and the time when these fish are at the worst, is likewise the worst time for fly fishing, both on account of the cold weather and because there are fewer flies on the water than at any other season. Even in December and January there are a few small gnats or water flies on the water in the middle of the day, in bright days, or when there is sunshine. These are generally black, and they escape the influence of the frost by the effects of light on their black bodies, and probably by the extreme rapidity of the motions of their fluids, and generally of their organs. They are found only at the surface of the water, where the temperature must be above the freezing point. In February a few double winged water flies which swim down the stream are 
usually found in the middle of the day,such as the willow fly; and the cow dung fly is sometimes carried on the water by winds. In March there are several flies found on most rivers. The grannam or green tail fly with a wing like a moth comes on generally morning and evening, from five till eight o'clock, А. м. in mild weather in the end of March and through April. Then there are the blue and the brown, both Ephemeræ, which come on, the first in dark days, the second in bright days; these flies when well imitated, are very destructive to fish. The first is a small fly with a palish yellow body, and slender beautiful wings, which rest on the back as it floats down the water. The second, called the cob in Wales, is three or four times as large, and has brown wings, which likewise protrude from the back, and its wings are shaded like those of a partridge, brown and yellow brown. These three kinds of flies lay their eggs in the water, which produce larvæ that remain in the state of worms, feeding and breathing in the water till they are prepared for their 
metamorphosis and quit the bottoms of the rivers, and the mud and stones, for the surface, and the light and air. The brown fly usually disappears before the end of April, likewise the grannam; but of the blue dun, there is a succession of different tints, or species, or varieties, which appear in the middle of the day all the summer and autumn long. These are the principal flies on the Wandle - the best and clearest stream near London. In early spring these flies have dark olive bodies; in the end of April and the beginning of May they are found yellow; and in the summer they become cinnamon coloured; and again, as the winter approaches, gain a darker hue. I do not, however, mean to say that they are the same flies, but more probably successive generations of Ephemeræ of the same species. The excess of heat seems equally unfavourable, as the excess of cold, to the existence of the smaller species of water insects, which during the intensity of sunshine seldom appear in summer, but rise morning and evening only. The blue dun has in 
June and July a yellow body, and there is a water fly which in the evening is generally found before the moths appear, called the red spinner. Towards the end of August, the Ephemeræ appear again in the middle of the day: a very pale small Ephemera which is of the same colour as that which is seen in some rivers in the beginning of July. In September and October this kind of fly is found with an olive body, and it becomes darker in October, and paler in November. There are two other flies which appear in the end of September and continue during October if the weather be mild: a large yellow fly with a fleshy body and wings like a moth; and a small fly with four wings, with a dark or claret coloured body, that when it falls on the water has its wings like the great yellow fly, flat on its back. This, or a claret bodied fly, very similar in character, may be likewise found in March or April, on some waters. In this river I have often caught many large trout in April and the beginning of May, with the blue dun, having the yellow body; and in the upper 
part of the stream below St. Albans, and between that and Watford, I have sometimes, even as early as April, caught fish in good condition: but the true season for the Colne is the season of the May fly. The same may be said of most of the large English rivers containing large trouts, and abounding in May fly:-such as the Test and the Kennet; the one running by Stockbridge, the other by Hungerford. But in the Wandle at Carshalton' and Beddington, the May fly is not found; and the little blues are the constant, and when well imitated, killing flies on this water; to which may be joined a dark alder fly, and a red evening fly. In the Avon, at Ringwood and Fordingbridge, the May fly is likewise a killing fly; but as this is a grayling river, the other flies, particularly the grannam and blue and brown, are good in spring, and the alder fly or pale blue later, and the blue dun in September and October, and even November. In the streams in the mountainous parts of Britain, the spring and autumnal flies are by far the most killing. 
The Usk was formerly a very productive trout stream, and the fish being well fed by the worms washed down by the winter floods, were often in good season, cutting red, in March, and the beginning of April: and at this season the blues and browns, particularly when the water was a little stained after a small flood, afforded the angler good sport. - In Herefordshire and Derbyshire, where trout and grayling are often found together, the same periods are generally best for angling; but in the Dove, Lathkill, and Wye, with the natural May fly many fish may be taken; and in old times, in peculiarly windy days, or high and troubled water, even the artificial May fly, according to Cotton, was very killing.

Poiet.-I have heard various accounts of the excellent fishing in some of the great lakes in Ireland. Can you tell us anything on the subject, and if the same flies may be used in that island.

- HaL. - I have been several times in Ireland, but riever at this season, which is considered as best for lake fishing. I 
have heard that in some of the lakes in Westmeath, very large trout, and great quantities may be taken in the beginning of June, with the very flies we have been using this day. Wind is necessary; and a good angler sometimes takes in a day, or rather formerly took, from ten to twelve fish, which weighed from 3 to $10 \mathrm{lbs}$. and which occasionally were even larger. In the summer after June, and in the autumn, the only seasons when I have fished in Ireland, I have seldom taken any large trout; but in the river Boyle, late in October, after a flood, I once had some sport with these fish, that were running up the river from Lock Key to spawn. I caught one day two above $3 \mathrm{lbs}$. that took a large reddish-brown fly of the same kind as a salmon fly; and I saw some taken that weighed $5 \mathrm{lbs}$. and heard of one that equalled $9 \mathrm{lbs}$. These fish were in good season, even at this late period, and had no spots, but were coloured red and brown-mottled like tortoiseshell, only with smaller bars. I have in July likewise fished in Loch Con, near Ballina, 
and Loch Melvin, near Ballyshannon. In Loch Con, the party caught many small good trout, that cut red; and in the other I caught a very few trout only, but as many of them were gillaroo or gizzard trout as common trout.

Poiet.-This must have been an interesting kind of fishing. In what does the gillaroo differ from the trout?

HaL.-In appearance very little, except that they have more red spots, and a yellow or golden coloured belly and fins, and are generally a broader and thicker fish; but internally they have a different organization, possessing a large thick muscular stomach, which has been improperly compared to a fowl's, and which generally contains a quantity of small shell fish of three or four kinds: and though in those I caught the stomachs were full of these shell fish, yet they rose greedily at the fly.

Poiet.-Are they not common trout which have gained the habit of feeding on shell fish?

HaL. - If so, they have been altered in a 
succession of generations. The common trouts of this lake have stomachs like other trouts, which never as far as my experience has gone contain shell fish; but of the gillaroo trout, I have caught with a fly some not longer than my finger, which have had as perfect a hard stomach as the larger ones, with the coats as thick in proportion, and the same shells within; so that this animal is at least now a distinct species, and is a sort of link between the trout and char, which has a stomach of the same kind with the gillaroo, but not quite so thick, and which feeds at the bottom in the same way. I have often looked in the lakes abroad for gillaroo trout, and never found one. In a large lake at the foot of the Crest of the Brennerabove 4,000 feet above the level of the sea, I once caught some trout, which, from their thickness and red spots, I suspected were gillaroo, but on opening the stomach I found I was mistaken, it had no particular thickness, and was filled with grasshoppers; but there were char, which fed on shell fish, in the same lake. 
Poiet.-Are water flies found on all rivers?

HAL.-This is a question which I find it impossible to answer; yet from my own experience I should suppose, that in all the habitable parts of the Globe certain water flies exist wherever there is running water. Even in the most ardent temperature, gnats and musquitoes are found, which lay their congeries of eggs on the water, which, when hatched, become first worms, afterwards small shrimp-like aurelia, and lastly flies. There are a great number of the largest species of these flies on stagnant waters and lakes, which form a part of the food of various fishes, principally of the carp kind: but the true fisherman's flies,- - those which are imitated in our art, principally belong to the northern, or at least temperate part of Europe, and I believe are nowhere more abundant than in England. It appears to me, that since I have been a fisherman, which is now the best part of half a century, I have observed in some rivers where I have been accustomed to fish habitually, a dimi- 
nution of the quantity of fly. There were always some seasons in which the temperature was favourable to a quantity of fly; for instance, fine warm days in spring for the grannam, or brown fly; and like days in May and June for the alder fly, May fly, and stone fly; but I should say that within these last twenty years I have observed a general diminution of the spring and autumnal flies, except in those rivers which are fed from sources that run from chalk, and which are almost perennial-such as the Wandle, and the Hampshire and Buckinghamshire rivers; in these streams the temperature is more uniform, and the quantity of water does not vary much. I attribute the change of the quantity of flies in the rivers to the cultivation of the country. Most of the bogs or marshes which fed many considerable streams are drained; and the consequence is that they are more likely to be affected by severe droughts and great floods - the first killing, and the second washing away the larvæ and aurelias. May flies thirty years ago were abundant in the upper 
part of the Teme, river in Herefordshire, where it receives the Clun: they are now seldom or rarely seen. And most of the rivers of that part of England, as well as of the west, with the exception of those that rise in the still uncultivated parts of Dartmoor and Exmoor, are after rain rapid and unfordable torrents, and in dry summers little more than scanty rills. And Exmoor and Dartmoor, almost the only great remains of those moist, spongy or peaty soils which once covered the greatest part of the high lands of England, are becoming cultivated, and their sources will gradually gain the same character as those of our midland and highly improved counties. I cannot give you an idea of the effects of peat mosses and grassy marshes on the water thrown down from the atmosphere, better, than by comparing their effects to those of roofs of houses of thatched straw, as contrasted with roofs of slate, on a shower of rain. The slate begins to drop immediately, and sends down what it receives in a rapid torrent, and is dry soon after the shower is over. The roof of 
thatch, on the contrary, sponge like, is long before the water drops from it; but it continues dropping and wet for hours after the shower is over and the slate is dry.

Poiet.-You spoke just now of the gillaroo trout, as belonging only to Ireland. I

\section{GILLAROO-LOCH MELVIN.}

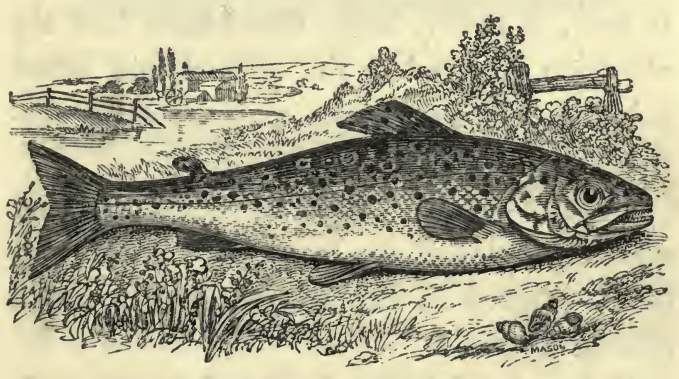

can, however, hardly bring myself to believe that such a fish must not be found elsewhere. For lakes with shell fish and char are common in various parts of Europe, and as the gillaroo trout is congenerous, it ought to be found both in Scotland and the Alpine countries. 
HaL. - It is not possible from analogies of this kind to draw certain inferences. Subterraneous cavities and subterranean waters are common in various countries, yet the Proteus Anguinus is only found in two places in Carniola - at Adelsburg and Sittich. As I mentioned before, I have never yet found a gillaroo trout except in Ireland. It is true, it is only lately that I have had my attention directed to the subject, and other fishermen or naturalists may be more fortunate.

Poret.-Have you ever observed any other varieties of the trout kind, which may be considered as, like the gillaroo, forming a distinct species?

HaL. - I think the par, samlet, or brandling, common to most of our rivers which communicate with the sea, has a claim to be considered a distinct species; yet the history of this fish is so obscure, and so little understood, that I perhaps ought not to venture to give an account of it. But in doing so, you will consider me as rather asking for 
new information, than as attempting a satisfactory view of this little animal.

\section{PAR, OR SAMLET.}
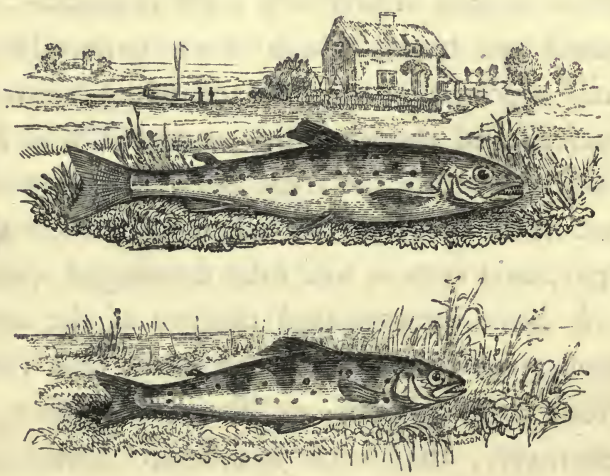

OrN.-I have seen this fish in the rivers of Wales and Herefordshire, and have heard it asserted, on what appeared to me good authority, that it was a mule,-the offspring of a trout and a salmon.

HAL.-This opinion, I know, has been supported by the fact, that it is found only in streams which are occasionally visited by salmon; yet I know no direct evidence in favour of the opinion, and I should think it much more probable, if it is a mixed race, 
that it is produced by the sea trout and common trout. In a small river which runs into the May, near Ballina in Ireland, I once caught in October a great number of small sea trout, which were generally of half a pound in weight, and which were all males; and unless it be supposed that the females were in the river likewise, and would not take the fly, these fish, in which the spermatic system was fully developed, could only have impregnated the ova of the common river trout. The sea trout and river trout are, indeed, so like each other in character, that such a mixture seems exceedingly probable; but I know no reason why such mules should always continue small, except that it may be a mark of imperfection. The only difference between the par and common small trout, is in the colours, and in its possessing one or two spines more in the pectoral fin. The par has large blue or olive bluish marks on the sides, as if they had been made by the impression of the fingers of a hand; and hence the fish is called in some places fingerling. The river 
and sea trout seem capable of changing permanently their places of residence; and sea trout seem often to become river trout. In this case they lose their silvery colour, and gain more spots; and in their offspring. these changes are more distinct. Fish, likewise, which are ill-fed remain small; and pars are exceedingly numerous in those rivers where they are found, which are never separated from the sea by impassable falls; from which I think it possible that they are produced by a cross between sea and river trout. The varieties of the common trout are almost infinite; from the

\section{GREAT LAKE TROUT.}

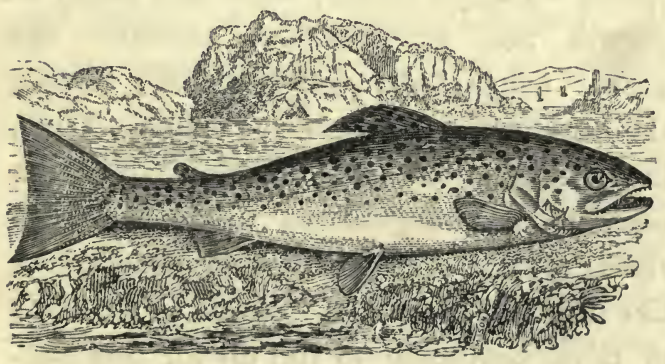


great lake trout, which weighs above 60 or rolbs., to the trouts of the little mountain brook or small mountain lake, or tarn, which is scarcely larger than the finger. And the smallest trout spawns nearly at the same time with the larger ones, and their ova are of the same size; but in the large trout there are tens of thousands, and in the small one rarely as many as forty,-often from ten to forty. So that in the physical constitution of these animals, their production is diminished as their food is small in quantity; and it is remarkable that the ova of the large and beautiful species which exist in certain lakes, and which seem always to associate together, appear to produce offspring which, in colour, form, and power of growth and reproduction, resemble the parent fishes; and they generally choose the same river for their spawning. Thus, in the lake of Guarda, the Benacus of the ancients, the magnificent trout, or Salmo fario, which in colour and appearance is like a fresh run salmon, spawns in the river at Riva, beginning to run up for that pur- 
pose in June, and continuing to do so all the summer; and this river is fed by streams from snow and glaciers in the Tyrol, and is generally foul: whilst the small spotted common trouts, which are likewise found in this lake, go into the small brooks which have their sources not far off, and in which they were probably originally bred. And I have seen taken in the same net small fish of both these varieties, which were as marked as possible in their characters:one silvery, like a young salmon, blue on the back and with small black spots only; the other, with yellow belly and red spots, and an olive-coloured back. I have made similar observations in other lakes, particularly in that of the Traun near Gmünden, and likewise at Loch Neah in Ireland. Indeed, considering the sea trout as the type of the species trout, it is, I think, probable that all the other true trouts may be considered as varieties, where the differences of food and of habits have occasioned, in a long course of ages, differences of shape and colours, transmitted to offspring in the same 
manner as in the variety of dogs, which may all be referred to one primitive type.*

* I have known the number of spines in the pectoral fins different, in different varieties of trout; I have seen them 12,13, and $14:$ but the anal fin always (I believe) contains 10 or 11 spines. The smallest brook trout, when well and copiously fed, will increase in stews to four or five pounds in weight, but never attains the size or characters of lake trout.

Mr. Tomkin of Polgaron put some small river trout, $2 \frac{1}{2}$ inches in length, into a newly made pond. He took some of them out the second year, above 12 inches in length; the third year, he took one out of 16 inches in length; and the fourth year, one of 25 inches in length: this was in 1734. (Carew's Survey of Cornwall, p. 87.) 


\section{( 73 )}

\section{THIRD DAY.}

\section{Halieus-Poietes-Ornither- \\ Physicus.}

\section{SCENE-DENHAM.}

\section{Morning.}

HaL.-You will soon take your leave, gentlemen, of this agreeable villa, but we must catch at least two brace of trout, to carry with us to London as a present for two worthy patrons of the angle. The May fly is already upon the water, though not in great quantity, and it will consequently be more easy to catch the fish, which I see are rising with great activity. I advise you to go to the deep water below, where you will find large fish, and I will soon follow you.

Poiet.-I hope I shall catch a large fish, -a companion to that which you took yesterday with a natural fly. 
[Halieus leaves them fishing, and returns to the House; but soon comes back and joins his companions, whom he finds fishing below in the river.]

HaL.-Well, gentlemen, what sport?

Poiet.-The fish are rising every where; but though we have been throwing over them with all our skill for a quarter of an hour, yet not a fish will take, and I am afraid we shall return to breakfast without our prey.

HaL. - I will try; but I shall go to the other side, where I see a very large fish rising. There!-I have him at the very first throw. Land this fish, and put him into the well. Now I have another fish; and I have no doubt I could take half a dozen in this very place, where you have been so long fishing without success.

Phys. - You must have a different fly; or have you some unguent or charm to tempt the fish?

HaL. - No such thing. If any of you will give me your rod and fly, I will an- 
swer for it I shall have the same success. I take your rod, Physicus.-And lo! I have a fish!

Phys.-What can be the reason of this? It is perfectly inexplicable to me. Yet Poietes seems to throw as light as you do, and as well as he did yesterday.

HAL.-I am surprised that you, who are a philosopher, cannot discover the reason of this. Think a little.

\section{All. - We cannot.}

HaL. - As you are my scholars, I believe I must teach you. The sun is bright, and you have been, naturally enough, fishing with your backs to the sun, which, not being very high, has thrown the shadows of your rods and yourselves upon the water, and you have alarmed the fish whenever you have thrown a fly. You see I have fished with my face towards the sun, and though inconvenienced by the light, have not alarmed the fish. Follow my example, and you will soon have sport, as there is a breeze playing on the water.

Phys.-Your sagacity puts me in mind 
of an anecdote which I remember to have heard respecting the late eloquent statesman, Charles James Fox; who, walking up Bond Street from one of the club houses with an illustrious personage, laid him a wager that he would see more cats than the Prince in his walk, and that he might take which side. of the street he liked. When they got to the top, it was found that Mr. Fox had seen thirteen cats, and the Prince not one. The royal personage asked for an explanation of this apparent miracle; Mr. Fox said, "Your Royal Highness took, of course, the shady side of the way, as most agreeable; I knew that the sunny side would be left to me, and cats always prefer the sunshine."

HaL.-There! Poietes; by following my advice you have immediately hooked a fish; and while you are catching a brace, I will tell you an anecdote, which is as much related to fly fishing as that of Physicus, and which affords an elucidation of a particular effect of light.

A manufacturer of carmine, who was aware of the superiority of the French. 
colour, went to Lyons for the purpose of improving his process, and bargained with the most celebrated manufacturer in that capital for the acquisition of his secret, for which he was to pay a thousand pounds. He was shown all the processes, and saw a beautiful colour produced, and he found not the least difference in the French mode of fabrication and that which he had constantly adopted. He appealed to the manufacturer, and insisted that he must have concealed something. The manufacturer assured him that he had not, and invited him to see the process a second time. He minutely examined the water and the materials, which were the same as his own, and very much surprised, said, "I have lost my labour and my money, for the air of England does not permit us to make good carmine." "Stay," says the Frenchman, "do not deceive yourself: what kind of weather is it now?" "A bright sunny day," said the Englishman. "And such are the days," said the Frenchman, " on which I make my 
colour. Were I to attempt to manufacture it on a dark or cloudy day, my result would be the same as yours. Let me advise you, my friend, always to make carmine on bright and sunny days." "I will," says the Englishman; " but I fear I shall make very little in London."

Poiet.-Your anecdote is as much to the purpose as Physicus's; yet I am much obliged to you for the hint respecting the effect of shadow, for I have several times in May and June had to complain of too clear a sky, and wished, with Cotton, for
A day with not too bright a beam;
A warm, but not a scorching, sun.

HaL.-Whilst we have been conversing, the May flies, which were in such quantities, have become much fewer; and I believe the reason is, that they have been greatly diminished by the flocks of swallows which every where pursue them: I have seen a single swallow take four, in less than a quarter of a minute, that were descending to the water. 
PoIET.-I delight in this living landscape! The swallow is one of my favourite birds, and a rival of the nightingale; for he glads my sense of seeing as much as the other does my sense of hearing. He is the joyous prophet of the year--the harbinger of the best season: he lives a life of enjoyment amongst the loveliest forms of nature: winter is unknown to him; and he leaves the green meadows of England in autumn, for the myrtle and orange groves of Italy, and for the palms of Africa:-he has always objects of pursuit, and his success is secure. Even the beings selected for his prey are poetical, beautiful, and transient. The ephemeræ are saved by his means from a slow and lingering death in the evening, and killed in a moment, when they have known nothing of life but pleasure. $\mathrm{He}$ is the constant destroyer of insects,- the friend of man; and with the stork and the ibis, may be regarded as a sacred bird. His instinct, which gives him his appointed seasons, and which teaches him always when 
and where to move, may be regarded as flowing from a Divine Source; and he belongs to the Oracles of Nature, which speak the awful and intelligible language of a present Deity. 


\section{( 81$)$}

\section{FOURTH DAY.}

\section{Halieus-Poietes-Ornither- \\ Physicus.}

FISHING FOR SALMON AND SEA TROUT.

SCEne-Loch Maree, West of Rophin, Scotland. Time-Middle of July.

Poiet.-I begin to be tired. This is really

a long day's journey; and these last ten miles through bogs, with no other view than that of mountains half hid in mists, and brown waters that can hardly be called lakes; and with no other trees than a few stunted birches, that look so little alive that they might be supposed immediately descended from the bog-wood, every where scattered beneath our feet. This is the most barren part of one of the most desolate countries I have ever passed through in Europe; and though the inn at Strathgarve 
is tolerable, that of Auchnasheen is certainly the worst I have ever seen,- and I hope the worst I shall ever see. We ought to have good amusement at Pool Ewe, to compensate us for this uncomfortable day's journey.

HaL. - I trust we shall have sport, as far as salmon and sea trout can furnish sport. But the difficulties of our journey are almost over. See, Loch Maree is stretched at our feet, and a good boat with four oars will carry us in four or five hours to our fishing ground: and that time will not be mispent, for this lake is not devoid of beautiful, and even grand scenery.

Poiet.-The scenery begins to improve; and that cloud-breasted mountain on the left is of the best character of Scotch mountains : these woods, likewise, are respectable for this northern country. I think I see islands, also, in the distance : and the quantity of cloud always gives effect to this kind of view ; and perhaps, without such assistance to the imagination, there would be nothing even approaching to the sublime in these countries; but cloud and mist, by 
creating obscurity and offering a substitute for greatness and distance, give something of an Alpine and majestic character to this region.

Ors.-As we are now fixed in our places in the boat, you will surely put out a rod or two with a set of flies, or try the tail of the par for a large trout or salmon: our fishing will not hinder our progress.

HAL. - In most other lakes I should do so; here I have often tried the experiment, but never with success. This lake is extremely deep, and there are very few fish which haunt it generally except char; and salmon seldom rest but in particular parts along the shore, which we shall not touch. Our voyage will be a picturesque, rather than an angling one. I see we shall have little occasion for the oars, for a strong breeze is rising, and blowing directly down the lake; we shall be in it in a minute. Hoist the sails! On we go!-we shall make our voyage in half the number of hours I had calculated upon; and I hope to catch a salmon in time for dinner. 
Poiet.-The scenery improves as we advance nearer the lower parts of the lake. The mountains become higher, and that small island or peninsula presents a bold craggy outline; and the birch wood below it, and the pines above, make a scene somewhat Alpine in character. But what is that large bird soaring above the pointed rock, towards the end of the lake? Surely it is an eagle!

HAL. - You are right, it is an eagle, and of a rare and peculiar species-the grey or silver eagle, a noble bird! From the size of the animal, it must be the female; and her aery is in that high rock. I dare say the male is not far off.

Phys. - I think I see another bird, of a smaller size, perched on the rock below, which is similar in form.

HaL.-You do: it is the consort of that beautiful and powerful bird; and I have no doubt their young ones are not far off.

Point.-Look at the bird! She dashes into the water falling like a rock, and raising a column of spray; she has fallen from a. 
great height. And now she rises again into the air; what an extraordinary sight!

HaL. - She is pursuing her prey, and is one of our fraternity, - a catcher of fish. She has missed her quarry this time, and has moved further down towards the river, and falls again from a great height. There! You see her rise with a fish in her talons.

Poiet.-She gives an interest which I hardly expected to have found to this scene. Pray are there many of these animals in this country?

HaL. - Of this species, I have seen but these two, and I believe the young ones migrate as soon as they can provide for themselves; for this solitary bird requires a large. space to move and feed in, and does not allow its offspring to partake its reign, or to live near it. Of other species of the eagle, there are some in different parts of the mountains, particularly of the Osprey; and of the great fishing or brown eagle; and I once saw a very fine and interesting sight in one of the Crags of Ben Weevis, near Strathgarve, as I was going, on the 20th of 
Aúgust, in pursuit of black game. Two parent eagles were teaching their offspring -two young birds, the manœuvres of flight. They began by rising from the top of a mountain in the eye of the sun, (it was about mid-day, and bright for this climate). They at first made small circles, and the young birds imitated them; they paused on their wings, waiting till they had made their first flight, and then took a second and larger gyration,-always rising towards the sun, and enlarging their circle of flight so as to make a gradually. extending spiral. The young ones still slowly followed, apparently flying better as they mounted; and they continued this sublime kind of exercise, always rising till they became mere points in the air, and the young ones were lost, and afterwards their parents, to our aching sight. But we have touched the shore, and the lake has terminated: you are now on the river Ewe.

Poiet.-Are we to fish here? It is a broad clear stream, but I see no fish, and cannot think it a good angling river. 
HaL. - We are nearly a mile above our fishing station, and we must first see our quarters and provide for our lodging, before we begin our fishing: we must walk a little way before we find the inn.

Poiet.-Why this inn is a second edition of Auchnasheen.

HaL.-The interior is better than the exterior, thanks to the Laird of Brahan: we shall find one tolerable room and bed; and we must put up our cots and provide our food. What is our store, Mr. Purveyor?

Phys. - I know we have good bread, tea, and sugar. Then there is the quarter of roebuck we got at Gordon Castle; and Ornither has furnished us with a brace of wild ducks, three leash of snipes, and a brace of golden plovers, by his mountain expedition of yesterday; and for fish we depend on you. Yet our host says there are fresh herrings to be had, and small cod-fish, and salmon and trout in any quantity, and the claret and the Ferintosh are safe.

HaL.-Why we shall fare sumptuously. As it is not time yet for shooting grouse, we 
must divide our spoil for the few days we shall stay here. Yet there are young snipes and plovers on the mountains above, and I have no doubt we might obtain the Laird's permission to kill a roebuck in the woods or a hart in the mountains; but this is always an uncertain event, and I advise you Ornither to become a fisherman.

ORN.-I shall wait till I see the results of your skill. At all events, in this country I can never want amusement, and I dare say there are plenty of seals at the mouth of the river, and killing them is more useful to other fishermen, than catching fish.

HaL.-Let there be a kettle of water with salt ready boiling in an hour, mine host, for the fish we catch or buy; and see that the potatoes are well dressed: the servants will look to the rest of our fare. Now for our rods.

Poict.-This is a fine river; clear, full, but not too large: with the two handed rod it may be commanded in most parts.

HAL.-It is larger than usual. The strong wind which brought us so quickly 
down has raised it; and it is not in such good order for fishing as it was before the wind rose.

Poiet.-I thought the river was always the better for a flood, when clear.

HaL.-Better after a flood from rain; for this brings the fish up, who know when rain is coming, and likewise brings down food and makes the fish feed. But when the water is raised by a strong wind the fish never run, as they are sure to find no increase in the spring heads, which are their objects in running.

Poiet. - You give the fish credit for great sagacity.

HaL.-Call it instinct rather; for if they reasoned, they would run with every large water, whether from wind or rain. What the feeling or power is which makes them travel with rain, I will not pretend to define. But now for our sport.

Poict.-The fish are beginning to rise; I have seen two here already, and there is a third, and a fourth-scarcely a quarter of a minute elapses without a fish rising in some parts of the pool. 
$\mathrm{HAL}_{\text {. }}$ - As the day is dark, I shall use a bright and rather a large fly, with jay's hackle, kingfisher's feather under the wing, and golden pheasant's tail, and wing of mixed grouse and argus pheasant's tail. I shall throw over these fish: I ought to raise one.

Poiet.-Either you are not skilful, or the fish know their danger: they will not rise.

HAL. - I will try another and a smaller fly.

Poiet.-You do nothing.

HaL. - I have changed my fly a third. time, yet no fish rises. I cannot understand this. The water is not in good order; but I should certainly have raised a fish or two. Now I will wager ten to one that this pool has been fished before to-day.

\section{Orn.-By whom?}

HaL. - I know not; but take my wager and we will ascertain.

ORN. - I shall ascertain without the wager if possible. See, a man connected with the fishing advances, let us ask him.-There you see; it has been fished once or twice by one, who claims without charter the right. of angling. 
HaL. - I told you so. Now I know this, I shall put on another kind of fly, such as I am sure they have not seen this day.

Poret.-It is very small and very gaudy, I believe made with humming bird's feathers.

HaL. - No. The brightest Java dove's hackle; kingfisher's, blue and golden pheasant's feathers, and the red feathers of the paroquet. There was a fish that rose and missed the fly - a sea trout. There, he has taken it, a fresh run fish, from his white belly and blue back.

Poret.-How he springs out of the water! He must be 6 or \%lbs.

HaL.-Under five, I am sure; he will soon be tired. He fights with less spirit: put the net under him. There, he is a fine fed sea trout, between 4 and 5lbs. But our intrusive brother angler (as I must call him,) is coming down the river to take his evening cast. A stout Highlander, with a powerful tail,--or, as we should call it in England, suite. He is resolved not to be driven off, and I am not sure that the Laird himself could divert him from his purpose, except 
by a stronger tail, and force of arms; but I will try my eloquence upon him. "Sir, we hope you will excuse us for fishing in this pool, where it seems you were going to take your cast; but the Laird has desired us to stand in his shoes for a few days, and has given up angling while we are here; and as we come nearly a thousand miles for this amusement, we are sure you are too much of a gentleman to spoil our sport; and we will take care to supply your fish kettle while we are here morning and evening, and we shall send you, as we hope, a salmon before night."

Poiet.-He grumbles good sport to us, and is off with his tail: you have hit him in the right place. He is $\mathrm{I}$ am sure a pot fisher, and somewhat hungry, and provided he gets the salmon does not care who catches him!

HaL. - You are severe on the Highland gentleman, and I think extremely unjust. Nothing could be more ready than his assent, and a keen fisherman must not be expected to be in the best possible humour 
when he finds sport which he believes he has a right to, and which perhaps he generally enjoys without interruption, taken away from him by entire strangers. There is, I know, a disputed point about fishing with the rod, between him and the Laird; and it would have been too much to have anticipated a courteous greeting from one who considers us as the representatives of an enemy. But I see there is a large fish which has just risen at the tail of the pool. I think he is fresh run from the sea, for the tide is coming in. My fly and tackle are almost too fine for so large a fish, and I will put on my first fly with a very strong single gut link and a stretcher of triple gut. He. has taken my fly, and I hold him-a powerful fish: he must be between 10 and $15 \mathrm{lbs}$. He fights well and tries to get up the rapid at the top of the pool. I must try my strength with him to keep him off that rock, or he will break me. I have turned him, and he is now in a good part of the pool: such a fish cannot be tired in a minute, but requires from ten to twenty times as long, 
depending upon his activity and strength, and the rapidity of the stream he moves against. He is now playing against the strongest rapid in the river and will soon give in if he keeps his present place.

Poiet.-You have tired him.

$\mathrm{H}_{\mathrm{AL}}$ - - He seems fairly tired: I shall bring him in to shore. Now gaff him; strike as near the tail as you can. $\mathrm{He}$ is safe; we must prepare him for the pot. Give him a stunning blow on the head to deprive him of sensation, and then give him a transverse cut just below the gills, and crimp him by cutting to the bone on each side, so as almost to divide him into slices; and now hold him by the tail that he may bleed. There is a small spring, I see, close under that bank, which I dare say has the mean temperature of the atmosphere in this climate, and is much under $50^{\circ}$-place him there, and let him remain for ten minutes, and then carry him to the pot, and let the water and salt boil furiously before you put in a slice, and give time to the water to recover its heat before you throw in another, 
and so with the whole fish, and leave the head out and throw in the thickest pieces first.

Puys.-Why did you not crimp your trout?

HaL. - We will have that fried. Our poacher prevented me from attending to the preparation of that fish; but for frying he is better not crimped, as he is not large enough to give good transverse slices.

Poiet.-This salmon is a good fish, and fresh as you said from the sea. You see the salt-water louse adheres to his sides, and he is bright and silvery and a thick fish: I dare say his weight is not less than 14lbs. and I know of no better fish for the table than one of that size.

$\mathrm{H}_{\mathrm{AL}}$. - Now we have caught fish for our dinner, my task is finished: Physicus and Poietes, try your skill: I have not fished over the best parts of this pool: you may catch a brace of fish here before dinner is ready.

Phys.-It is too late, and I shall go and see that all is right. 
96

Poret.-I will take one or two casts; but give me your fly: I like always to be sure that the tackle is taking:

HaL. - Try at first the very top of the pool,-though I fear you will get nothing there; but here is a cast which I think the Highlander can hardly have commanded from the other side, and which is rarely without a good fish. There, he rose: a large trout of 10lbs. or a salmon. Now wait a few minutes. When a fish has missed the fly, he will not rise again till after a pauseparticularly if he has been for some time in the fresh water. Now try him again. He has risen, but he is a dark fish that has been some time in the water, and he tries to drown the fly with a blow of his tail. I fear you will not hook him except foul, when most likely he would break you. Try the bottom of the pool, below where I caught my fish.

Poiet.-I have tried all the casts and nothing rises.

$\mathrm{H}_{\mathrm{AL}}$.-Come we will change the fly for that with which I caught my trout. 
Poiet.-Now I have one: he has taken the fly under water, and I cannot see him.

HaL. - Straighten your line and we shall soon see him. He is a sea trout, but not a large one.

Poiet.-But he fights like a salmon, and must be near 5 lbs.

HaL.-Under 3lbs.; but these fish are always strong and active, and sometimes give more sport than larger fish. Shorten your line or he will carry you over the stones and cut the link gut. He is there already: you have allowed him to carry out too much line, wind up as quick as you can, and keep a tight hand upon him. He is now back in a good place, and in a few minutes more will be spent. I have the net. There, he is a sea trout of nearly 3 lbs. This will be a good addition to our dinner: I will crimp him, that you may compare boiled sea trout with broiled, and with salmon. Now, if you please we will cool this fish at the spring, and then go to our inn.

Poict.-If you like. I am endeavouring to find a reason for the effect of crimping 
and cold in preserving the curd of fish. Have you ever thought on this subject?

HaL. - Yes: I conclude that the fat of salmon between the flakes, is mixed with much albumen and gelatine, and is extremely liable to decompose, and by keeping it cool the decomposition is retarded, and by the boiling salt and water, which is of a higher temperature than that of common boiling water, the albumen is coagulated, and the curdiness preserved. The crimping, by preventing the irritability of the fibre from being gradually exhausted, seems to preserve it so hard and crisp, that it breaks under the teeth; and a fresh fish not crimped is generally tough. A friend of mine, an excellent angler, has made some experiments on the fat of fish; and he considers the red colour of trout, salmon, and char, as owing to a peculiar coloured oil, which may be extracted by alcohol; and this accounts for the want of it in fish that have fed ill, and after spawning. In general, the depth of the red colour, and the quantity of curd are proportional. 
Poret.-Would not the fish be still better, or at least possess more curd, if caught in a net and killed immediately? In the operation of tiring by the reel there must be considerable muscular exertion, and I should suppose expenditure of oily matter.

HAL. - There can be no doubt but the fish would be in a more perfect state for the table from the nets; yet a fish in high season does not lose so much fat during the short time he is on the hook as to make much difference; and I am not sure that the action of crimping after does not give a better sort of crispness to the fibre: this, however, may be fancy; we will discuss the matter again at table. See! our companion on the lake, the eagle, is coming down the river, and has pounced upon a fish in the pool near the river.

Phys.-I fear he will interfere with our sport: let us request Ornither to shoot him. I wish to see him nearer and to preserve him as a specimen for the Zoological Society.

$\mathrm{H}_{\mathrm{AL}}-\mathrm{O}$ ! no. He will not spoil our sport; and I think it would be a pity to н 2 
deprive this spot of one of its poetical ornaments. Besides, the pool where he is now fishing contains little but trouts; it is too shallow for salmon, who run into the cruives.

Poret.-I am of your opinion; and shall use my eloquence to prevent Ornither from attempting the life of so beautiful a bird; so majestic in its form, so well suited to the scenery, and so picturesque in all its habits.

The Innkeeper.-Gentlemen, dinner is ready.

\section{THE DINNER.}

HaL. - Now take your places. What think you of our fish?

Phys.-I never ate better; but I want the Harvey or Reading sauce.

HaL. - Pray let me entreat you to use no other sauce than the water in which he was boiled. I assure you this is the true Epicurean way of eating fresh salmon: and for the trout, use only a little vinegar and mustard, - a sauce à la Tartare, without the onions.

Poret.-Well, nothing can be better; and 
I do not think fresh net-caught fish can be superior to these.

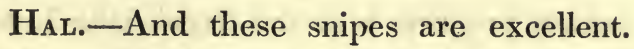
Either my journey has given me an appetite, or I think they are the best I ever tasted.

OrN.-They are good, but I have tasted better.

HaL.-Where?

Orn.-On the continent; where the common snipe, that rests during its migration from the north to the south in the marshes of Italy and Carniola, and the double or solitary snipe, become so fat as to resemble that bird which was formerly fattened in Lincolnshire, the ruff; and they have, I think, a better flavour from being fed on their natural food.

HaL. - At what time have you eaten them?

OrN.-I have eaten them both in spring and autumn; but the autumnal birds are the best, and are like the ortolan of Italy.

HaL. - Where does the double snipe winter?

Orn. - I believe in Africa and Asia minor. They are rarely. seen in England, except 
driven by an east wind in the spring, or a strong north wind in the autumn. Their natural progress is to and from Finland and Siberia, through the continent of Europe to and from the east and south.* In autumn they pass more east, both because they are aided by west winds, and because the marshes in the east of Europe are wetter in that season; and in spring they return, but a larger proportion through Italy, where they are carried by the Sirocco, and which at that time is extremely wet. Come, let us. have another bottle of claret: a pint per man is not too much after such a day's fatigue.

HAL. - You have made me president for these four days, and I forbid it. A half

* From the food, or rather I should say the remains of food, found in the stomach of the double snipe, I think it is probable that it requires a kind of worm, which is not found in winter even in the temperate climes of Europe; and that it feeds differently from the snipe. There are certainly none found after the middle of October, in either Illyria or Italy; and I believe the same may be said of the middle of May, as to their summer migration, or their breeding migration. 
pint of wine for young men in perfect health is enough, and you will be able to take your exercise better, and feel better for this abstinence. How few people calculate upon the effects of constantly renewed fever in our luxurious system of living in England! The heart is made to act too powerfully, the blood is thrown upon the nobler parts, and with the system of wading adopted by some sportsmen, whether in shooting or fishing, is delivered either to the hemorhoidal veins, or what is worse, to the head. I have known several free livers who have terminated their lives by apoplexy, or have been rendered miserable by palsy, in consequence of the joint effects of cold feet and too stimulating a diet; that is to say as much animal food as they could eat, with a pint or perhaps a bottle of wine per day. Be guided by me, my, friends, and neither drink nor wade. I know there are old men who have done both and have enjoyed perfect health; but these are devil's decoys to the unwary, and ten suffer for one that escapes, I could quote to you an instance from this very county, one of the 
strongest men I have ever known. He was not intemperate, but he lived luxuriously, and waded as a salmon fisher for many years in this very river; but before he was fifty, palsy deprived him of the use of his limbs, and he is still a living example of the danger of the system which you are ambitious of adopting.

Orn.-Well, I give up the wine, but I intend to wade in Hancock's boots to morrow.

HaL.--Wear them, but do not wade in them. The feet must become cold in a stream of water constantly passing over the caoutchouc and leather, notwithstanding the thick stockings. They are good for keeping the feet warm, and I think where there is exercise, as in snipe shooting, may be used without any bad effects. But I advise no one to stand still (which an angler must do sometimes) in the water, even with these ingenious waterproof inventions. All anglers should remember old Boerhaave's maxims of health, and act upon them: "Keep the feet warm, the head cool, and the body open." 
Phys.-I am sorry we did not examine more minutely the weight and size of the fish we caught, and compare the anatomy of the salmon and the sea trout; but we were in too great a hurry to see them on the table, and our philosophy yielded to our hunger.

$\mathrm{H}_{\mathrm{AL}}$ - We shall have plenty of opportunities for this examination; and we can now walk down to the fishing house and see probably half a hundred fish of different sizes, that have been taken in the cruives, this evening, and examine them at our leisure.

\section{AlL. - Let us go!}

Phys. - I never saw so many fish of this kind before; and I conclude that heap of smaller fish is composed of trout.

HaL.-Certainly. Let us compare one of the largest trout with a salmon. I have selected two fresh run fish, which, from their curved lower jaws, are, I conclude, both males. The salmon you see is rather broader, has a tail rather more forked, and the teeth in proportion are rather smaller. 

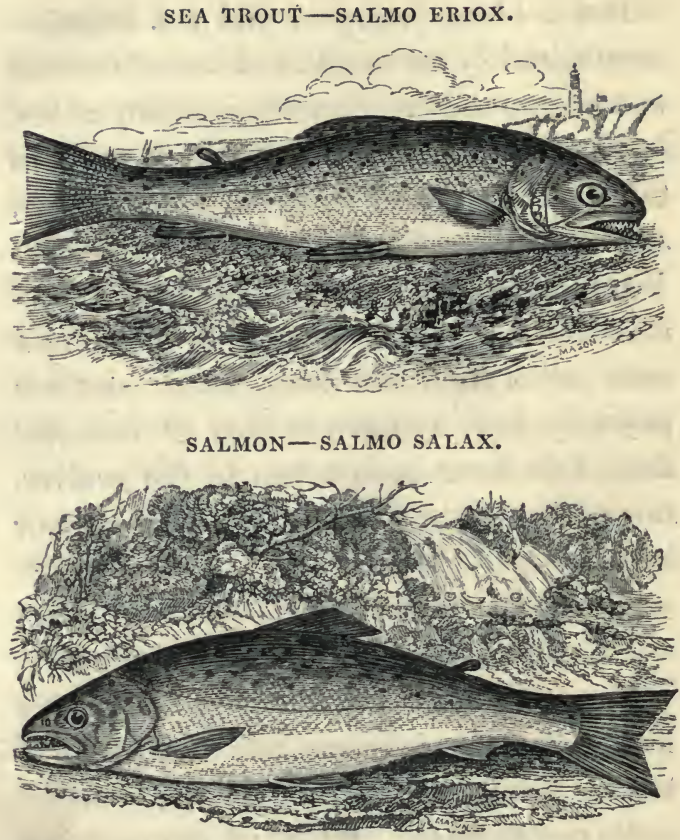

The trout, likewise, has larger and more black and brown spots on the body; and the head of the trout is rather larger in proportion. The salmon has 14 spines in the pectoral fins, 10 in each of the ventral, 13 in the anal, 21 in the caudal, and 15 in the 
TROUT AND SALMON COMPARED. 107

dorsal. The salmon measures $38 \frac{1}{2}$ inches in length, and 21 inches in girth, and his weight is $22 \frac{1}{4} \mathrm{lbs}$. you see. The trout has one spine less in the pectoral and two less in the anal fin, and measures $30 \frac{1}{4}$ inches in length, and 16 inches in girth, and his weight is $11 \mathrm{lbs}$. We will now open them. The stomach of the salmon, you see, contains nothing but a little yellow fluid, and, though the salmon is twice as large, does not exceed much in size that of the trout. The stomach of the trout, unlike that of the salmon, is full of food: we will open it. See, there are half digested sand eels which come out of it.

Phys.--But surely the stomachs of salmon must sometimes when opened contain food?

HaL. - I have opened ten or twelve, and never found anything in their stomachs but tape worms, bred there, and some yellow. fluid; but I believe this is generally owing to their being caught at the time of migration, when they are travelling from the sea upwards, and when they do not willingly load themselves with food. Their digestion seems to be very quick, and their habits 
seem to show, that after having taken a bait in the river they do not usually offer to take another, till the work of digestion is nearly performed; but when they are taken at sea, and in rivers in the winter, food, I am told, is sometimes found in their stomachs. The sea trout is a much more voracious fish, and, like the land trout, is not willingly found with an empty stomach.

Phys.-I presume the sea trout is the fish called by Linnæus, in his Fauna, Salmo Eriox?

HaL. - I know not: but I should rather think that fish a variety of the common salmon.

Phys.-But there are surely other species of salmon that live in the sea and come into our rivers: I have heard of fish called greys, bull trout, scurfs, morts, peales, and whitlings.

HaL. I have never been able to identify more than the salmo salac, or salmon, and salmo trutta, or sea trout, in the rivers of Britain and Ireland: The whitlings, I believe to be the young of the sea trout. A 
sea trout which I saw in Ireland, called a bull trout, was of the same kind as these you see here, but fresh water trout are sometimes carried in floods to the sea, and come back larger and altered in colour and form, and are then mistaken for new species; and as each river possesses a peculiar variety belonging to it, this, with differences depending upon food and size, will, I think, account for the peculiarities of particular fish, without the necessity of supposing them distinct species. I remember many years ago, the first time I ever fished for salmon in spring in the Tweed, I caught with the fly, one fine morning in March, two fish nearly of the same length: one was a male fish of the last season, that had lost its melt; the other a female fresh from the sea. They were so unlike, that they did not appear of the same species: the spent or kipper salmon was long and lean, showing an immense head, spotted all over with black and brown spots, and the belly almost black; the other bright and silvery, without spots, and the head small. Even the pectoral and anal fins had more 
spines in the newly run fish, some of the smaller ones having been probably rubbed off in spawning by the other. I would not for some time, till assured by an experienced fisherman, believe that the spent fish was a salmon; and when their flesh was compared on the table, one was white, flabby, and bad, and without curd; the other of the brightest pink, and full of dense curd. Then, though of the same length, one weighed only $4 \mathrm{lbs}$. the other $9 \frac{1}{2} \mathrm{lbs}$. When it is recollected that different salmon and sea trout spawn at different times in the same river, and that fish of the same year being born at different seasons, from Christmas to Lady-day, -and having migrated to the sea in spring-run up the rivers of all sizes in summer and autumn - the young salmon from 2 to $10 \mathrm{lbs}$. in weight, the young sea trout from $\frac{1}{2}$ to $3 \mathrm{lbs}$. in weight-it is not difficult to account for the variety of names given by casual observers to individuals of these two species. 


\section{( 111$)$}

\section{FIFTH DAY.}

Halieus-Poietes-Ornither-

Physicus.

M O R N I N G.

HAL. - WELL, is your tackle all ready? It is a fine fresh and cloudy morning, with a gentle breeze-a day made for salmon fishing.

[They proceed to the river.]

HaL. - Now, my friends, I give up the two best pools to you till one o'clock; and I shall amuse myself above and below-probably with trout fishing. As there is a promise of a mixed day, with-what is rare in this country-a good deal of sunshine, I will examine your flies a little, and point out those I think likely to be useful; or rather, I will show you my flies, and, as you all have 
duplicates of them, you can each select the fly which I point out, and place it in a part of the book where it may easily be found. First: when the cloud is on, I advise one of these three golden twisted flies, silk bodies, orange, red and pale blue, with red, orange, and grey hackle, golden pheasant's hackle for tail, and kingfisher's and golden pheasant's brown hackle under the wing; beginning with the brightest fly, and changing to the darker one. Should the clouds disappear, and it become bright, change your flies for darker ones, of which I will point out three:- a fly with a brown body and a red cock's hackle, and one with a dun body and black hackle, with a brown mallard's wing. All these flies have, you see, silver twist bodies, and all kingfisher's feather under the wing, and golden pheasant's feather for the tail. For the size of your flies, I recommend the medium size, as the water is small this day; but trying all sizes, from the butterfly size of a hook of half an inch in width, to one of a quarter. Now, Physicus, cast your orange fly into that rapid at the 
top of the pool; I saw a large fish run there this moment. You fish well, were common. trout your object; but, in salmon fishing, you must alter your manner of moving the fly. It must not float quietly down the water; you must allow it to sink a little, and then pull it back by a gentle jerk-not raising it out of the water,-and then let it sink again, till it has been shown in motion, a little below the surface, in every part of your cast. That is right,- - he has risen,

Phys.-I hold him. He is a noble fish!

$\mathrm{HAL}_{\mathrm{A}}$ - - He is a large grilse, I see by his play; or a young salmon, of the earliest born this spring. Hold him tight; he will fight hard.

Phys.-There! he springs out of the water! Once, twice, thrice, four times! He is a merry one!

HAL.-He runs against the stream, and will soon be tired,-but do not hurry him. Pull hard now, to prevent him from running round that stone. He comes in. I will gaff him for you. I have him! A goodly fish of this tide. But see, Poietes has a 
larger fish, at the bottom of the great pool, and is carried down by him almost to the sea.

Poiet. - I cannot hold him! He has run out all my line.

HaL. - I see him: he is hooked foul, and I fear we shall never recover him, for he is going out to sea. Give me the rod,-I will try and turn him; and do you run down to the entrance of the pool, and throw stones, to make him, if possible, run back. Ay! - that stone has done good service; he is now running up into the pool again. Now call the fisherman, and tell him to bring a long pole, to keep him if possible from the sea. Now you have a good assistant, and I will leave you, for tiring this fish will be at least a work of two hours. He is not much less than 20 lbs. and is hooked under the gills, so that you cannot suffocate him by a straight line. I wish you good fortune; but should he turn sulky, you must not allow him to rest, but make the fisherman move him with the pole again; your chance of killing him depends upon his being kept incessantly in 
action, so that he may exhaust himself by exercise. I shall go and catch you some river trout, for your dinner;-but I am glad to see, before I take my leave of you, that Ornither has likewise hold of a fish,-and, from his activity, a lusty sea trout.

[He goes, and returns in the afternoon.]

Hat. - Well, Poietes, I hope to see your fish of $20 \mathrm{lbs}$.

Poiet.-Alas! he broke me,-turned sulky, and went to the bottom; and when he was roused again, my line came back without the fly; so that I conclude he had cut my links by rubbing them against some sharp stone. But, since, I have caught two grilses and a sea trout, and lost two others, salmons or grilses, that fairly got the hooks out of their mouths.

Hat. - And, Ornither, what have you done? Well, I see,-a salmon, a grilse, and a sea trout. And Physicus?

Phys.-I have lost three fish; one of which broke me, at the top of the pool, by 
running amongst the rocks; and I have only one small sea trout.

HAL.-Your fortune will come another day. Why, you have not a single crimped fish for dinner, and it is now nearly two o'clock; and you have been catching for the picklers, for those fish may all go to the boiling house. I must again be your purveyor. Can you point out to me any part of this pool where you have not fished?

AlL. -No.

HAL. - Then I have little chance.

Prys.-O yes! you have a charm for catching fish.

HaL.-Let me know what flies you have tried, and I may perhaps tell you if I have a chance. With my small bright humming bird, as you call it, I will make an essay.

Poiet.-But this fishery is really very limited; and two pools for four persons a small allowance.

HaL. - If you could have seen this river twenty years ago, when the cruives were a mile higher up, then you might have enjoyed fishing. There were eight or ten pools, of 
SALMON RIVERS.-TAY AND TWEED. 117

the finest character possible for angling, where a fisherman of my acquaintance has hooked thirty fish in a morning. The river was then perfect, and it might easily be brought again into the same state; but even as it is now, with this single good pool and this second tolerable one, I know no place where I could, in the summer months, be so secure of sport as here-certainly no where in Great Britain.

Poret.-I have often heard the Tay and the Tweed vaunted as salmon rivers.

HAL. - They were good salmon rivers, and are still very good, as far as the profit of the proprietor is concerned; but, for angling, they are very much deteriorated. The net fishing, which is constantly going on except on Sundays and in close time, suffers very few fish to escape; and a Sunday's flood offers the sole chance of a good day's sport, and this only in particular parts of these rivers. I remember the Tweed and the Tay in a far better state. The Tweed, in the late Lord Somerville's time, always contained taking-fish after every flood in the 
summer : and, between Abbotsford and Melrose, I have known.six or seven fish taken by a single rod in the morning. In the Tay, only ten years ago, at Mickleure, I was myself one of two anglers who took eight fine fish,-three of them large salmon, -in a short morning's fishing; but now, except in spring fishing, when the fish are little worth taking, there is no certainty of sport in these rivers; and one, two, or three fish (which last is of rare occurrence), are all even an experienced angler can hope to take in a day's skilful and constant angling.

Poiet.-You have fished in most of the salmon rivers of the north of Europe,-give us some idea of the kind of sport.

HaL.-I have fished in some, but perhaps not in the best; for this it is necessary to go into barbarous countries-Lapland, or the extreme north of Norway; and I have generally loved too much the comforts of life to make any greater sacrifices than such as are made in this expedition. I have heard the river at Drontheim boasted of as an excellent salmon river,-and I know two worthy 
anglers who have tried it; but I do not think they took more fish in a day than I have sometimes taken in Scotland and Ireland. All the Norwegian rivers, that I tried, (and they were all in the south of Norway,) contained salmon. I fished in the Glommen, one of the largest rivers in Europe; in the Mandals, which appeared to me the best fitted for taking salmon; the Avendal and the Torrisdale;-but, though I saw salmon rise in all these rivers, I never took any fish larger than a sea trout; of these I always took many - and even in the fiords, or small inland salt-water bays; but I think never any one more than a pound. It is true, I was in Norway in the beginning of July, and in exceedingly bright weather, and when there was no night; for even at twelve o'clock the sky was so bright, that I read the smallest print in the columns of a newspaper. I was in Sweden later-in August: I fished in the magnificent Gotha, below that grand fall Trolhetta, which to see is worth a voyage from England; but I never raised there any fish worth taking: yet a 
gentleman from Gothenburg told me he had formerly taken large trout there. I took, in this noble stream, a little trout about as long as my hand; and the only fish I got to eat at Trolhetta was bream. The Falkenstein, a darker water, very like a second-rate Scotch river-say the Don-abounds in salmon; and there I had a very good day's fishing. I took six fish, which gave me great sport; they were grilses, under $6 \mathrm{lbs}$; ; but I lost a salmon, which I think was above $10 \mathrm{lbs}$. This river I conceive must be, generally, excellent; it is not covered with saw-mills, like the Norwegian rivers in general; its colour is good, and it is not so clear as most of the rivers of the south of Norway.

Phys.-Do you think the saw-mills hurt the fishing?

HaL.-I do not doubt it. The immense quantity of sawdust which floats in the water, and which forms almost hills along the banks, must be poisonous to the fish, by sometimes choaking their gills and interfering with their respiration." I have never fished for salmon in Germany. The Elbe and the 
Weser, when I have seen them, were too foul for fly fishing; and in the Rhine, in Switzerland, and its tributary streams, I have never seen a salmon rise. I once hooked a fish, under the fall at Schaffausen, which in my youthful ardour I thought was a salmon, but it turned out to be an immense chub-a villanous and provoking substitute. And our islands, as far as I know, may claim the superiority over all other lands for this species of amùsement. In England it is, however, a little difficult to get a day's salmon fishing. The best river I know of is the Derwent, that flows from the beautiful Lake of Keswick; and I caught once, in October, a very large salmon there, and raised another; but it is only late in the autumn that there is any chance of sport there, though I have heard the spring salmon fishing boasted of. At Whitwell, in the Hadder, I have heard of salmon and sea trout being taken-but I have never fished in that river. The late Lord Bolinbroke caught many salmon at Christchurch; but a fish a week is as much as can be expected in 
that beautiful, but scantily stocked, river. Small salmon and sea trout, or sewens, as they are called in the country, may be caught, after the autumnal floods, I believe, in most of the considerable Welsh, Devonshire, and Cornish streams; but I have fished in many of them without success. The Conway I may except: this river, in the end of October, will sometimes, after a great flood, furnish a good day's sport,-and if the net fishers could be set aside, several day's sport. I have known two salmon, one above $201 \mathrm{lbs}$. , taken here in a day; and I have taken myself fine sea trout, or sewens, - which, in an autumnal flood in Wales, are found in most of the streams near the sea.

Poret.-I have heard a Northumberland man boast of the rivers of that county, as affording good salmon fishing.

HaL. - I have no doubt that salmon are sometimes caught in the Tyne, the Coquet, and the Till; but, in the present state of these rivers, this is a rare occurrence. I was once, for a week, on a good run of the North Tyne; I fished sometimes, but I 
never saw a salmon rise; and the only place in this river where, from my own knowledge, I can assert salmon have been caught with the artificial fly, was at Mounsey, very high up the river. There, in 1820, two grilses were caught, in the end of August. I have recorded this as a sort of historical occurrence; and I dare say most of the counties of England in which there are salmon rivers, would, upon a minute inquiry, furnish such instances, if they contained salmon fishers. Yorkshire, Devonshire, and Cornwall, with the sea on both sides, ought to furnish a greater number.

Phys.-Give us some little notice of the Scotch and Irish rivers.

HAL. - I fear I shall tire you by attempting any details on this subject, for they are so many, that I ought to take a map in my hands; but I will say a few words on those in which $I$ have had good sport. First, the Tweed:- of this, as you will understand from what I mentioned before, I fear I must now say "fuit." Yet still, for spring salmon fishing, it must be a good river. The last 
great sport I had in that river was in 1817 , in the beginning of April. I caught, in two or three hours, at Merton, above four or five large salmon, and as many in the evening at Kelso-and one of them 25lbs. But this kind of fishing cannot be compared to the summer fishing: the fish play with much less energy, and in general are in bad season; and the fly used for fishing is almost like a bird-four or five times larger than the summer fly, and the coarsest tackle may be employed. I have heard that Lord Home has sometimes taken thirty fish in a day, in spring fishing. About, and above, Melrose, I have taken, in a morning in July, two or three grilses; and in September the same number: and I have known eighteen taken earlier, by an excellent salmon fisher, at Merton; and the late Lord Somerville often took six or seven fish in a day's angling. The same, "fuit," I must apply to most of the Scotch rivers. Of the Tay I have already spoken. The Dee I have never caught salmon in, though $I$ have fished in two parts of it, but in bad seasons. In the 
Don I have seen salmon rise, and hooked one, but never killed a fish. In the Spey I enjoyed one of the best day's sport (perhaps the very best) I ever had in my life: it was in the beginning of September, in close time; the water was low, and as net fishing had been given over for some days, the lower parts were full of fish. By a privilege, which I owe to the late Duke of Gordon, I fished at this forbidden time, and hooked twelve or thirteen fish in one day. One was above $30 \mathrm{lbs}$. who broke me by the derangement of my reel. I landed seven or eight,-one above $20 \mathrm{lbs}$. which gave me great play in the rapids above the bridge. I returned to the same spot in 1813, the year after; the river was in excellent order, and it was the same time of the year, but just after a flood,-I caught nothing; the fish had all run up the river; the pools, where I had had such sport the year before, were empty. I have fished there since, with a like result,-but this was before the 12th of August, the close day. In the Sutherland and Caithness rivers, many salmon, I have no doubt, may still be 
caught. The Brora, in 1813 and 1814, was an admirable river; I have often rode from the mansion of the princely and hospitable lord and lady of that county, after breakfast, and returned at two or three o'clock, having taken from three to eight salmon-several times eight. There were five pools below the wears of the Brora, which always contained fish; and one pool, which from its size was almost inexhaustible, at the top of which I have taken three or four salmon the same day. Another pool, nearer the sea, was almost equal to it; and at that time I should have placed the Brora above the Ewe for certainty of sport. When I fished there last, in 181\%, the case was altered, and I caught only two or three fish in those places where I had six years before been so successful. In the Helmsdale there are some good pools, and I have caught fine fish there when the river has been high. I have fished in the river at Thurso, but without success - it was always foul when I made my essay. I have heard of a good salmon river in Lord Reay's country, the Laxford; 
its name, of Norwegian origin, would seem to be characteristic.* Along the coast of Scotland, most of the streams, if taken at the right time, afford sport. The Ness, at Inverness, and the Arne and Lochy, I have fished in, but without success. I may say the same of the Ayr, and of the rivers which empty themselves into the Solway Frith. A little preserved stream, at Ardgowan, was formerly excellent, after a flood in September, for sea trout, and later for salmon: I have had good sport there, and some of my friends have had better.

In Ireland there are some excellent rivers; and what you will hardly believe possible, comparing the characters of the two nations, some of them are taken better care of than the Scotch rivers; which arises a good deal from the influence of the Catholic priests, when they are concerned in the interests of the proprietors, or the Catholic peasantry. I should place the Erne, at Ballyshannon, as now the first river, for salmon fishing from the banks with a rod, in the British

* Lax is the Teutonic word for salmon. 
dominions; and the excellent proprietor of it, Dr. Thiel, is liberal and courteous to all gentlemen fly fishers. The Moy, at Ballina, is likewise an admirable salmon river; and sport, I believe, may almost always be secured there in every state of the waters; but the best fishing can only be commanded by the use of a boat.' I have taken in the Erne two or three large salmon in the morning; and in the Moy, three or four grilses, or, as they are called in Ireland, grauls; and this was in a very bad season for salmon fishing. The Bann, near Coleraine, abounds in salmon: but except in close time, when it is unlawful to fish there, there are few good casts in this river. In the Bush, a small river about seven miles to the east of the Bann, there is admirable salmon fishing always after great floods; but in fine and dry weather there is little use in trying this river. I have hooked twenty fish in a day, after the first August floods, in this river; and, should sport fail, the celebrated Giant's Causeway is within a mile of its mouth, and offers to the lovers of natural beauty, 
or of geological research, almost inexhaustible sources of interest. The Blackwater, at Lismore, is a very good salmon river: and the Shannon, above Limerick and at Castle Connel, whenever the water is tolerably high, offers many good casts to the fly fisher; but they can only be commanded by boats. But there is no considerable river along the northern or western coast; -with the exception of the Avoca, which has been spoiled by the copper mines,that does not afford salmon, and that does not, if taken at the proper time, offer sport to the salmon fisher.-But it is time for us to return to our inn.

\section{THE INN.}

Poiet.-Should it be a fine day to-morrow, I think we shall have good sport: the high tide will bring up fish, and the rain and wind of yesterday will have enlarged the river.

HAL. - To-morrow we must not fish: it is the Lord's day, and a day of rest. It ought 
likewise to be a day of worship and thanksgiving to the great cause of all the benefits and blessings we enjoy in this life, for which we can never sufficiently express our gratitude.

Porex.-I cannot see what harm there can be in pursuing an amusement on a Sunday, which you yourself have called innocent, and which is apostolic: nor do I know a more appropriate way of returning thanks to the Almighty Cause of all being, than in examining and wondering at his works in that great temple of nature, whose canopy is the sky; and where all the beings and elements around us are as it were proclaim-. ing the power and wisdom of Deity.

HAL. - I cannot see how the exercise of fishing can add to your devotional feelings; but independent of this, you employ a servant to carry your net and gaff, and he, at least, has a right to rest on this one day. But even if you could perfectly satisfy yourself as to the abstracted correctness of the practice, the habits of the country in which we now are, form an insurmountable obstacle 
to the pursuit of the amusement: by in: dulging in it, you would excite the indignation of the Highland peasants, and might perhaps expiate the offence by a compulsory ablution in the river.

Poiet.-I give up the point: I make it a rule never to shock the prejudices of any person, even when they appear to me ridiculous; and I shall still less do so in a case where your authority is against me; and I have no taste for undergoing persecution, when the cause is a better one. I now remember that I have often heard of the extreme severity with which the sabbath discipline is kept in Scotland. Can you give us the reason of this?

HaL, - I am not sufficiently read in the Church History of Scotland to give the cause historically; but I think it can hardly be doubted that it is connected with the intense feelings of the early Covenanters, and their hatred with respect to all the forms and institutes of the Church of Rome, the ritual of which makes the Sunday more a $\mathrm{x} 2$ 
day of innocent recreation, than severe discipline.

- Phys.-Yet the disciples of Calvin, at Geneva, who, I suppose, must have hated the pope as much as their brethren of Scotland, do not so rigidly observe the Sunday; and I remember having been invited by a very religious and respectable Genevese to a shooting party on that day.

HaL:-I think climate and the imitative nature of man modify this cause abroad. Geneva is a little state in a brighter climate than Scotland, almost surrounded by Catholics, and the habits of the French and Savoyards must influence the people. The Scotch with more severity and simplicity of manners, have no such examples of bad neighbours, for the people of the north of England keep the Sunday much in the same way.

Point.-Nay, Halieus, call them not bad neighbours; recollect my creed, and respect at least, what, if error, was the error of the Christian world for 1000 years. The rigid 
observance of the-seventh day appears to me rather a part of the Mosaic, than of the Christian dispensation. The Protestants of this country consider the Catholics bigots, because they enjoin to themselves, and perform certain penances for their sins; and surely the Catholics may see a little more. like that spirit in the interference of the Scotch in innocent amusements, on a day celebrated as a festive day, that on which our Saviour rose into immortal life, and secured the everlasting hopes of the Christian. I see no reason why this day should not be celebrated with singing, dancing, and triumphal processions, and all innocent signs of gladness and joy. I see no reason why it should be given up to severe and solitary prayers, or to solemn and dull walks; or why, as in Scotland, whistling even should be considered as a crime on Sunday, and humming a tune, however sacred, out of doors; as a reason for violent anger and persecution.

OrN.-I agree with Poietes, in his views of the subject. I have suffered from the 
peculiar habits of the Scotch Church, and therefore may complain. Once in the north of Ireland, when a very young man, I ventured after the time of Divine Service, to put together my rods, as I had been used to do in the Catholic districts of Ireland, and fish for white trout in the river at Rathmelton, in pure innocence of heart, unconscious of wrong, when I found a crowd collect round me - at first I thought from mere curiosity, but I soon discovered I was mistaken; anger was their motive and vengeance their object. A man soon came up exceedingly drunk, and began to abuse me by various indecent terms: such as a Sabbath breaking papist, \&c. It was in vain I assured him I was no papist, and no intentional Sabbath breaker; he seized my rod and carried it off with imprecations; and it was only with great difficulty, and by rousing by my eloquence some women who were present, and who thought I was an ill-used stranger, that I recovered my property. Another time I was walking on Arthur's Seat, with some of the most distinguished 
professors of Edinburgh attached to the geological opinions of the late Dr. Hutton, a discussion took place upon the phenomena presented by the rocks under our feet, and to exemplify a principle, Professor Playfair broke some stones, in which I assisted the venerable and amiable philosopher. We had hardly examined the fragments, when a man from a crowd, who had been assisting at a field preaching, came up to us and warned us off, saying, "Ye think ye are only stane breakers; but I ken ye are Sabbath breakers, and ye deserve to be staned with your ain stanes!"

HaL.-Zeal of every kind is sometimes troublesome, yet I generally suspect the persons who are very tolerant of scepticism. Those who firmly believe that a particular plan of conduct is essential to the eternal welfare of man, may be pardoned if they show even anger, if this conduct is not pursued. The severe observance of the Sabbath is connected with the vital creed of these rigid presbyterians; it is not therefore extraordinary that they should enforce it 
even with a perseverance that goes beyond the bounds of good manners and courtesy. They may quote the example of our Saviour, who expelled the traders from the temple even by violence.

Phys.-I envy no quality of the mind or intellect in others; not genius, power, wit, or fancy: but if I could choose what would be most delightful, and I believe most useful to me, I should prefer a firm religious belief to every other blessing; for it makes life a discipline of goodness-creates new.hopes, when all earthly hopes vanish; and throws over the decay, the destruction of existence, the most gorgeous of all lights; awakens life even in death, and from corruption and decay calls up beauty and divinity: makes an instrument of torture and of shame the ladder of ascent to paradise; and far above all combinations of earthly hopes, calls up the most delightful visions of palms and amaranths, the gardens of the blest, the security of everlasting joys, where the sensualist and the sceptic view only gloom, decay, annihilation, and despair! 


\section{( 137 )}

\section{SIXTH DAY.}

Halieus-Poietes-OrnitherPhysicus.

M O R N I N G.

HaL. - Well met, my friends! It is a fine warm morning, there is a fresh breeze, the river is in excellent order for fishing, and I trust our good behaviour yesterday will ensure us sport to day. There must be a great many fresh run fish in the pool; and after twenty-four hours rest, some of those that were indisposed to take on Saturday eyening, may have acquired appetite. Prepare your tackle and begin: but whilst you are preparing I will mention a circumstance which every accomplished fly fisher ought to know, you changed your flies on Saturday with the change of weather,-putting the dark flies on for the bright gleams of the 
sun, and the gaudy flies when the dark clouds appeared. Now I will tell you of another principle which it is as necessary to know, as the change of flies for change of weather; I allude to the different kinds of fly to be used in particular pools, and even for particular parts of pools. You have fished in this deep pool; and if you were to change it for a shallower one, such as that above, it would be proper to use smaller flies of the same colour; and in a pool still deeper, larger flies; likewise in the rough rapid at the top, a larger fly may be used than below at the tail of the water: and in the Tweed or Tay, I have often changed my fly thrice in the same pool, and sometimes with success-using three different flies for the top, middle, and bottom. I remember when I first saw Lord Somerville adopt this fashion, I thought there was fancy in it; but experience soon proved to me how accomplished a salmon fisher was my excellent and lamented friend, and $I$ adopted the lesson he taught me, and with good results, in all bright waters. 
Poret.--I will try the correctness of your principle. Look at the fly now on my line; where would you recommend me to cast it?

HAL.- It is a large gaudy fly, and is fit for no part of this pool, except the extremely rough head of the torrent: there I dare say it will take in this state of the waters.

Poiet.-Good, I hooked a large fish, but alas! he is off: yet I thought he was fairly caught.

HAL. - The hook, I think, turned round at the moment you struck, and carried off some scales from the outside of his mouth.

Poret.-You are right: see, the scales are on the hook. I cannot raise another fish: I have tried almost all over the pool. I thought I saw a fish rise at the tail of the rapid.

HaL.-You did: he refused the fly. Now put on a fly one third of the size and of the same colour, and I think you will hook that fish.

Poiet. - I have done so - and he is fast! and a fine fish; I think a salmon.

HAL.-It is a salmon, and one above 
10lbs. Play him with care; and do not let him run into the rough part of the stream where the large stones are.

Poiet.-It is, I think, the most active fish I have yet played with. See, how high he leaps! He is making for the sea.

HAL.-Hold him tight, or you will lose him.

Poiet.-Fear me not. I trust in spite of his strength I shall turn him. You see I show him the but of the rod, and his force is counterpoised by a very long lever.

HaL. - You do well. - But he has made a violent spring, and, I fear, is off.

Poiet.-He is!-but, I think, not by any fault of mine: he has carried off something.

HaL. - You played that fish so well, that I am angry at his loss: either hook, link, or line, failed you.

Poiet.-It is the hook, which you see is broken not merely at the barb, but likewise in the shank. What a fool I was, ever to use one of these London or Birmingham made hooks.

HAL. - The thing has happened to me 
often. I now never use any hooks for salmon fishing, except those which I am sure have been made by O'Shaugnessy, of Limerick; for even the hooks made in Dublin, though they seldom break, yet they now and then bend, and the English hooks made of cast steel in imitation of Irish ones, are the worst of all. There is a fly nearly of the same colour as that which is destroyed; and I can tell you that I saw it made at Limerick by O'Shaughnessy himself, and tied on one of his own hooks. Should you catch with it a fish even of 30lbs. I will answer for its strength and temper: it will neither break nor bend.

Point.-Whilst I am attaching your kind present to my line, pray tell me how these hooks are made, for I know you interested yourself in this subject when at Limerick.

HaL. - Most willingly. I have even made a hook, which though a little inferior in form, in other respects, I think, I could boast as equal to the Limerick hooks. The first requisite for hook-making, is to find good malleable iron of the softest and 
purest kind-such as is procured from the nails of old horse-shoes. This must be made by cementation with charcoal into good soft steel, and that into bars or wires of different thickness for different sized hooks, and then annealed. For the larger hooks, the bars must be made in such a form as to admit of cutting the barbs; and each piece, which serves for two hooks, is larger at the ends, so that the bar appears in the form of a double pointed spear, three, four, or five inches long: the bars for the finer hooks are somewhat flattened. The artist works with two files, one finer than the other for giving the point and polishing the hook, and begins by making the barb, taking care not to cut too deep, and filing on a piece of hard wood, such as box wood, with a dent to receive the bar made by the edge of the file. The barb being made, the shank is thinned and made flat, and the polishing file applied to it; and by a turn of the wrist round a circular pincers, the necessary degree of curvature is given to it. The hook is then cut from the bar, heated red 
hot, by being kept for a moment in a charcoal fire, then plunged while hot into cold water; then tempered by being put on iron that has been heated in the same fire till it becomes bright blue; and whilst still hot, it

- is immersed in candle-grease, where it gains a black colour; it is then finished.

Prys.-Nothing seems simpler than this process. Surely London might furnish manufacturers for so easy a manipulation; and I should think one of our friends, who is so admirable a cutler, might even improve upon the Irish process; at least the tempering might be more scientifically arranged; for instance, by the thermometer, and a bath of fusible metal, the temperature at which steel becomes blue being $580^{\circ} \mathrm{Fah}$. might be constantly preserved.

HaL.-Habit teaches our Irish artists this point with sufficient precision. We should have such hooks in England, but the object of the fishing tackle makers is to obtain them cheap, and most of their hooks are made to sell, and good hooks cannot be sold but at a good price. 
Poiet.-I have heard formerly a good angler complain that the Limerick hooks were too heavy and clumsy. He preferred hooks made at Kendal in Cumberland.

HAL. - I saw twenty years ago, hooks far too heavy made at Limerick; but this O'Shaughnessy is, I think, a better maker than his father was, and the curve and the general form of the hook is improved. It has now, I think, nearly the best form of a curve for catching and holding, the point protruding a little. The Kendal hook holds well, but is not so readily fixed by the pull in the mouth of the fish. The early Fellows of the Royal Society, who attended to all the useful and common arts, even improved fish hooks; and Prince Rupert, an active member of that illustrious body, taught the art of tempering hooks to a person of the name of Kirby; under whose name for more than a century, very good hooks were sold. I shall take a walk towards the lake to enjoy a view of its cloud-capped mountains, and $\mathbf{I}$ hope on my return to find that you have all 
had your satisfaction in a good day's salmon fishing.

Phys. - We shall crimp and cool a salmon, if we catch a good one, for our dinner.

HaL.-Do so.

Orn.-But before you leave us, I wish you would be good enough to inform us why the salmon here are so different from those I have seen elsewhere; for instance, some caught in the Alness, in Rosshire, which we saw in passing round the south coast of Ross. These appear to me, thicker and brighter fish, and one that I measured was 30 inches long, and 17 in circumference.

HaL. - I think I have seen broader fish than even those of this river; but the salmon which you happen to remember for comparison, belonged to a small stream, which, I think, in general are thinner and longer than those in great rivers; and what I mentioned on a former occasion with respect to trout, holds good likewise with regard to salmon; each river has a distinct kind. It is scarcely possible to doubt that the varieties of the salmon which haunt the sea, come to the 
same rivers to breed in which they were born, or where they have spawned before. And this could hardly happen unless they limited their migrations to a certain space in the sea, the boundaries of which may be regarded as the shore and probably deep water, which may be considered as effectual a boundary almost as land; for fish do not willingly haunt very deep water, which even in summer is of low temperature, approaching to $40^{\circ}$, and which contains little or no vegetable food or insects, which the smaller fishes search for, and the larger fishes follow the smaller. It is however possible, that in winter, all fish fond of heat will seek water rather deeper than in summer; and char and umbla in lakes are usually found in the deepest parts, being fond of conl water, and they come to spawn whenever the shallow water of the lakes becomes cool, in October or November. We cannot judge of the senses of animals which breathe water,which separate air from water by their gills; but it seems probable that as the quality of the water is connected with their life and 
health, they must be exquisitely sensible to changes in water, and must have similar relations to it, that an animal with the most delicate nasal organs has to air. A vulture or a dog scents not only particular food and particular game at great distances, but even makes of the smell a kind of language; and I doubt not that when dogs that have been blindfolded and carried away from their home, return to it, it is by the sense of smell: to them each town, lane, or field, must have a particular smell. And I have seen even a blind horse, an animal in which the sense of smell is less acute, evidently find his way by his sense of smell, to his master's house and stable, which was, indeed, near a tan-yard. The state of parts of water in the sea or great lakes produced by the impregnations carried down by particular streams, is much more permanent than a like state in air: so that though the knowledge given by the nasal organs may be more easily communicated at a distance by winds, yet that produced by streams on the bronchiæ of fishes is more invariable, 
so that a migratory fish is less likely to be deceived. Yet in great floods, often connected with storms, or violent motion in the waters near the shore, salmon sometimes mistake their river. I remember in this way, owing to a tremendous flood, catching with the fly a large salmon that had mistaken his river, having come into the Bush, near the Giant's Causeway, instead of the Bann. No fish can be more distinct in the same species than the fish of these two rivers, their length to their girth being nearly in a ratio of $20: 9$ and $20: 13$.--I am going; good sport to you.

\section{EVENING.}

HaL. - I am sure I may congratulate you on your sport, for I see on the bank a fine salmon, three grauls or grilses, and three large sea trout.

Orn.-You have not seen all, for we have crimped two fish-one a great salmon, and the other a trout almost a yard long, and both in excellent season. We have had great sport, and sport even of a kind which 
you will not guess at; for, when the tide was falling the fish ceased to rise at the fly, and I thought of trying them with a bait; so, we sent for our swivel tackle, and put par or samlet on our hooks, as we bait for pike-cutting off one ventral fin on one side, and one pectoral fin on the other; and making the par spin in the most rapid streams, we had several runs from fish, and it was in this way that Poietes caught this large sea trout, which gave excellent sport.

HAL. - This kind of fishing is not uncommon. I have often caught salmon in the Tay, fishing with pars; but though the fish ran at the bait when they would not rise at the fly while the tide was ebbing, they would have taken the par better still while it was flowing.

Phys.-From my experience to-day, I conclude the salmon has habits different from the trout; for I think the fish which broke my hook, rose again at the artificial fly in the same place.

HaL. - I think you are mistaken. Salmon 
are usually shyer even than trout, and I never knew one in this season that had been pricked even slightly, rise again at the artificial fly in the same pool. I should say that their habits were precisely the same, but with more sagacity on the side of the salmon. It must have been another fish which rose at your fly in the same place. After such severe discipline I do not think a fish would rise for many hours, even at a natural bait.

Poiet.-Your experience is so great, that I dare say I was mistaken, yet it seemed a fish of the same size.

HaL.-Salmon often in this season haunt the streams in pairs; but so far from rising again after being pricked, they appear to me to learn when they have been some time in the river, that the artificial fly is not food, even without having been touched by the hook. In the river at Galway, in Ireland, I have seen above the bridge some hundreds of salmon lying in rapid streams, and from five to ten fishermen tempting them with every variety of fly, but in vain. After a 
fish had been thrown over a few times, and risen once or twice and refused the fly, he rarely ever took any notice of it again in that place. It was generally nearest the tide that fish were taken, and the place next the sea was the most successful stand, and the most coveted; and when the water is low and clear in this river, the Galway fishermen resort to the practice of fishing with a naked hook, endeavouring to entangle it in the bodies of the fish; a most unartistlike practice. In spring fishing I have known a hungry half-starved salmon rise at the artificial fly a second time, after having been very slightly touched by it; but even this rarely happens, and when I have seen it, the water has been coloured.

Phys.-Can you tell us why the fish rise better at the fly when the tide is rising, than when it is falling? There seems no reason why flies should be sought for by the fish at one of these seasons, rather than at the other.

HAL. - The turn of the salt water brings. up aquatic insects, and perhaps small fish; 
and I suppose salmon know this, and search for food at a time when it is likely to be found. I cannot think that in these pools they can be on the look-out for flies, for there are none ever on the surface of the water; and I imagine they take the gaudy fly, with its blue kingfisher and golden pheasant's feathers, for a small fish.

OrN.-I have always supposed they took it for a libella, or dragon-fly; for I have often seen these brilliant flies haunting the water.

HaL.-I never saw a dragon-fly drop on the water, or taken by a fish; and salmon sometimes rise even in the salt water, where dragon flies are never found. There is no difficulty in explaining why salmon in inland rivers should take flies, where natural flies are abundant; but fish, when they have lain long in pools in the river and fed on natural flies, will no longer take these bright flies, and then even a trout fly is often most successful. I have sometimes thought that the rising of salmon and sea trout at these bright flies, as soon as they come from the sea into 
rivers, might depend upon a sort of imperfect memory of their early food and habits; for flies form a great part of the food of the salmon fry, which, for a month or two after they are hatched, feed like young troutsand in March and April the spring flies are their principal nourishment. In going báck to fresh water, they may perhaps have their habits of feeding recalled to them, and naturally search for their food at the surface.

PoIE'.-This appears to me very probable.-But it is late, and we must return and compare the crimped trout and salmon; and I hope we shall have another good day to-morrow, for the clouds are red in the west.

Phys.-I have no doubt of it, for the red has a tint of purple.

HAL. - Do you know why this tint portends fine weather?

Phys.-The air when dry, I believe, refracts more red, or heat-making, rays; and as dry air is not perfectly transparent, they are again reflected in the horizon. I have 
generally observed a coppery or yellow sunset to foretel rain; but, as an indication of wet weather approaching, nothing is more certain than a halo round the moon, which is produced by the precipitated water; and the larger the circle, the nearer the clouds, and consequently the more ready to fall.

HaL. - I have often observed that the old proverb is correct-

A rainbow in the morning is the shepherd's warning: A rainbow at night is the shepherd's delight.

Can you explain this omen?

Phys.-A rainbow can only occur when the clouds containing, or depositing, the rain are opposite to the sun, - and in the evening the rainbow is in the east, and in the morning in the west; and as our heavy rains, in this climate, are usually brought by the westerly wind, a rainbow in the west indicates that the bad weather is on the road, by the wind, to us; whereas the rainbow in the east proves, that the rain in these clouds is passing from us.

Poiet.-I have often observed, that when the swallows fly high, fine weather is to be 
expected or continued; but when they fly low, and close to the ground, rain is almost surely approaching. Can you account for this?

HaL.-Swallows follow the flies and gnats, and flies and gnats usually delight in warm strata of air; and as warm air is lighter, and usually moister, than cold air, when the warm strata of air are high; there is less chance of moisture being thrown down from them by the mixture with cold air; but when the warm and moist air is close to the surface, it is almost certain that, as the cold air flows down into it, a deposition of water will take place.

Poict.-I have often seen sea gulls assemble on the land, and have almost always observed that very stormy and rainy weather was approaching. I conclude that these animals, sensible of a current of air approaching from the ocean, retire to the land to shelter themselves from the storm.

Orn.-No such thing. The storm is their element; and the little petrel enjoys the heaviest gale, because, living on the 
smaller sea insects, he is sure to find his food in the spray of a heavy wave-and you may see him flitting above the edge of the highest surge. I believe that the reason of this migration of sea gulls, and other sea birds, to the land, is their security of finding food; and they may be observed, at this time, feeding greedily on the earth worms and larvæ, driven out of the ground by severe floods: and the fish, on which they prey in fine weather in the sea, leave the surface and go deeper in storms. The search after food, as we agreed on a former occasion, is the principal caúse why animals change their places. The different tribes of the wading birds always migrate when rain is about to take place; and I remember once, in Italy, having been long waiting, in the end of March, for the arrival of the double snipe in the Campagna of Rome,-a great flight appeared on the $3 \mathrm{~d}$ of April, and the day after heavy rain sat in, which greatly interfered with my sport. The vulture, upon the same principle, follows armies; and $I$ have no doubt that the augury 
of the ancients was a good deal founded upon the observation of the instincts of birds. There are many superstitions of the vulgar owing to the same source. For anglers, in spring, it is always unlucky to see single magpies, - but two may be always regarded as a favourable omen; and the reason is, that in cold and stormy weather one magpie alone leaves the nest in search of food, the other remaining sitting upon the eggs or the young ones; but when two go out together, it is only when the weather is warm and mild, and favourable for fishing.

Poiet. - The singular connections of causes and effects, to which you have just. referred, make superstition less to be wondered at, particularly amongst the vulgar; and when two facts, naturally unconnected, have been accidentally coincident, it is not singular that this coincidence should have been observed and registered, and that omens of the most absurd kind should be trusted in. In the west of England, half a century ago, a particular hollow noise on 
the sea coast was referred to a spirit or goblin, called Bucca, and was supposed to foretel a shipwreck: the philosopher knows that sound travels much faster than currents in the air-and the sound always foretold the approach of a very heavy storm, which seldom takes place on that wild and rocky coast, without a shipwreck on some part of its extensive shores, surrounded by the Atlantic.

Phys.-All the instances of omens you have mentioned are founded on reason; but how can you explain such absurdities as Friday being an unlucky day, the terror of spilling salt, or meeting an old woman? I knew a man, of very high dignity, who was exceedingly moved by these omens, and who never went out shooting without a bittern's claw fastened to his buttonhole by a ribband-which he thought ensured him good luck.

Poict.-These, as well as the omens of death watches, dreams, \&c. are for the most part founded upon some accidental coincidences; but spilling of salt, on an uncom- 
mon occasion, may, as I have known it, arise from a disposition to apoplexy, shown by an incipient numbness in the hand, and may be a fatal symptom; and persons, dispirited by bad omens, sometimes prepare the way for evil fortune; for confidence in success is a great means of ensuring it. The dream of Brutus, before the field of Pharsalia, probably produced a species of irresolution and despondency, which was the principal cause of his losing the battle: and I have heard that the illustrious sportsman to whom you referred just now, was always observed to shoot ill, because he shot carelessly, after one of his dispiriting omens.

HaL. - I have in life met with a few things which I found it impossible to explain, either by chance coincidences or by natural connections; and I have known minds of a very superior class affected by them,-persons in the habit of reasoning deeply and profoundly.

Phys.-In my opinion, profound minds are the most likely to think lightly of the resources of human reason; and it is the 
pert superficial thinker who is generally strongest in every kind of unbelief. The deep philosopher sees chains of causes and effects so wonderfully and strangely linked together, that he is usually the last person to decide upon the impossibility of any two series of events being independent of each other; and in science, so many natural miracles, as it were, have been brought to light, - such as the fall of stones from meteors in the atmosphere, the disarming a thunder cloud by a metallic point, the production of fire from ice by a metal white as silver, and referring certain laws of motion of the sea to the moon,- that the physical inquirer is seldom disposed to assert, confidently, on any abstruse subjects belonging to the order of natural things, and still less so on those relating to the more mysterious relations of moral events and intellectual natures. 


\section{(161)}

\section{SEVENTH DAY.}

Halieus-Poietes-OrnitherPhysicus.

GRAYLING FISHING.

SCENe-Leintwardine, near Ludlow.

Time-Beginning of October.

HaL. - You have reached your quarters. Here is your home-a rural, peaceable, and unassuming inn, with as worthy a host and hostess as may be found in this part of England. The river glides at the bottom of the garden, and there is no stream in England more productive of grayling. The surrounding scenery is not devoid of interest, and the grounds in the distance are covered with stately woods, and laid out (or rather their natural beauties developed) by the hand of a master, whose liberal and enlightened mind even condèscended to regard the 
amusements of the angler; and he could hardly have contributed in a more effectual manner to their comforts, than by placing the good people, who were once his servants, in this comfortable inn.

Phys.-Are we to fish according to any rule, as to quantity or size of fish?

HaL.-You are at perfect liberty to fish as you like; but as it is possible you may catch grayling only of this year, and which are not longer than the hand, I conclude you will return such pigmies to the river as a matter of propriety, though not of necessity.

Poiet.-This river seems formed of two other streams, which join above our inn. What are the names of its sources?

$\mathrm{H}_{\mathrm{AL}}$. - The small river to the left is called the Teme, or Little Teme, and though the least stream, it gives name to the river: the other, and more copious, stream, is called the Clun. The little Teme contains principally trout; the Clun, both trout and grayling: but the fish are more abundant in the meadows, between this place and 
Downton, than in other parts of the river; for above, the stream is too rapid and shallow to be favourable to their increase; and below, it is joined by other streams, and becomes too abundant in coarse fish.

Poiet.-I cannot understand why the grayling should be so scarce a fish in England. It is abundant in many districts on the continent; but in this island it is found, I believe, only in a few rivers, and does not exist, I think, either in Ireland or Scotland. Yet being an Alpine fish, and naturally fond of cool water, it might have been expected among the Highlands.

HaL. - I formerly used to account for this by supposing it an imported fish, and not indigenous; but, in some of my continental excursions, I have seen it living only under such peculiar circumstances, that I doubt the correctness of this my early opinion.

Poiet.-Which was, I conclude, that it was introduced by the monks, in the time when England was under the See of Rome. As a favourite fish of St. Ambrose it was worth cultivating, as well as for its own

M 2 
sake; and I think you have done wrong to relinquish this idea, for, as far as my recollection serves me, the rivers that contain it are near the ruins of great monasteries. The Avon, near Salisbury; the Ure, near Fountain's Abbey; the Wye, near the great Abbey of Tintern; and, if I am not mistaken, in the lower part of this valley there are the remains of an extensive establishment of friars.

$\mathrm{H}_{\mathrm{A}} \mathrm{L}$. - But there are rivers near the ruins of some of the most magnificent establishments of this kind in Europe, and those nearest the continent, where the grayling is not found; for instance, in the Stour, at Canterbury. And if the grayling be an imported fish, it is wonderful that it should not be found in the rivers in Kent, and along the south-west coast of England,-as in Dorsetshire, Devonshire, and Cornwall, -where the monastic establishments were numerous; and why it should be found in some rivers in the mountainous parts of Wales-as in that near Llan-wrted and the Dee; not near Val Crusis Abbey, but fif- 
teen miles higher up, between Corwen and Bala.

Poiet.- It may have been a fish imported from the continent, and carried to a number of rivers, only a few of which may have suited its habits, and there it has remained and multiplied.

HaL.-There may be truth in what you are now imagining, for the grayling requires a number of circumstances in a river to enable it to multiply.

Poiet.-What circumstances are these?

HaL. - A temperature in the water which must be moderate-neither too high nor too low. Grayling are never found in streams that run from glaciers-at least near their source; and they are killed by cold or heat. I once put some grayling from the Teme, in September, with some trout, into a confined water, rising from a spring in the yard at Downton; the grayling all died, but the trout lived. And in the hot summer of 1825, great numbers of large grayling died in the Avon, below Ringwood, without doubt killed by the heat in July.

Poiet.-But I have heard of grayling 
being common in Lapland-at least so says Linnæus.

HAL. - I think it must be another species of the same genus; the same as Back's grayling, found by Captain Franklin and his companions in North America, and distinguished by a much larger back fin. Having travelled with the fishing rod in my hand through most of the Alpine valleys in the south and east of Europe, and some of those in Norway and Sweden, I have always found the char in the coldest and highest waters; the trout, in the brooks rising in the highest and coldest mountains; and the grayling always lower, where the temperature was milder: and if in hot countries, only at the foot of mountains, not far from sources which had the mean temperature of the atmosphere,-as in the Vipacco, near Goritzia, and in the streams which gush forth from the limestone caverns of the Noric Alps. Besides temperature, grayling require a peculiar character in the disposition of the water of rivers. They do not dwell, like trout, in rapid shallow torrents; 
nor, like char or chub, in deep pools or lakes. They require a combination of stream and pool; they like a deep still pool for rest, and a rapid stream above, and a gradually declining shallow below, and a bottom where marl or loam is mixed with gravel; and they are not found abundant except in rivers that have these characters. It is impossible to see a more perfect specimen of a grayling river than that now running before us, in this part of its course. You see a succession of deep still pools under shady banks of marl, with gentle rapids above, and a long shelving tail, where the fish sport and feed. If there are no such pools in a river, grayling will remain, provided the water be clear, and will breed; but they cannot stem rapid streams, and they are gradually carried down lower and lower, and at last disappear. You know the Test, one of the finest trout streams in Hampshire, and of course in England; when I first knew this stream, twenty years ago, there were no grayling in it. A gentleman brought some from the Avon, and 
introduced them into the river at Longstock, above Stockbridge. They were for two or three years very abundant in that part of the river; but they gradually descended, and though they multiplied greatly, there are now scarcely any above Stockbridge. There were, four years ago, many in the river just below; but this year there are very few found there, and the great proportion that remains is found below Houghton. I ought to mention, that the water is particularly fitted for them, and they become larger in this river than in their native place, the Avon,- - some of them weighing between 3 and 4 lbs. The trout, in all its habits of migration, runs upward, seeking the fresh and cool waters of mountain sources to spawn in: the grayling, I believe, has never the same habit of running up stream; I never saw one leaping at a fall, where trout are so often seen. Their large back fin seems intended to enable them to rise and sink rapidly in deep pools; and the slender nature of the body, towards the tail, renders them much more unfit for leaping cataracts 
than trout and salmon. The temperature of the water, and its character as to still and stream, seem of more importance than clearness; for I have seen grayling taken in streams that are almost constantly turbid,as in the Inn and the Salza in the Tyrol. This fish appears to require food of a particular kind, feeding much upon flies and their larvæ, and not usually preying upon small fish, as the trout. It has a very strong stomach, almost approaching to that of the gillaroo trout, and is exceedingly fond of those larvæ which inhabit cases, and which, usually covered with sand or gravel, require a strong membraneous stomach to enable the extraneous matter to be separated. In accordance with their general habits of feeding, grasshoppers are amongst their usual food in the end of summer and autumn; and at all seasons, maggots, upon fine tackle and a small hook, offer a secure mode of taking them,--the pool having been previously baited for the purpose of angling, by throwing in a handful or two a few minutes before. 
Poiet.-You just now said, that you thought the Lapland fish considered by Linnæus as the grayling, was the same as Back's grayling; but I find in the Appendix to Capt. Franklin's narration, two graylings described as belonging to the northern regions, - one the Coregonus Signifer, and another which seems to differ very little from it, except being small in size. This seems to agree as nearly as possible with our grayling, with a difference of at most one spine in the back fin. May not this in fact be the same fish as the grayling of the Alps, only rendered in a succession of generations fit for a colder climate?

HaL.-This is certainly possible: there is no doubt that in many successive generations, animals may be fitted to bear changes which would have destroyed their progenitors. It is said by Block, that graylings are found in the Caspian Sea, and in the Baltic, -masses of saline water; though, as I have proved, the grayling of England will not bear even a brackish water, without dying. And notwithstanding the severity of the 
winter in high northern latitudes, streams under the ice may retain a temperature not much lower than some of the Alpine sources. I have seen grayling in Carnio'a, in a source not quite $50^{\circ}$; and as, in large bodies of water, the deepest part, in frost, is generally the warmest-about $40^{\circ}$, the temperature at which water is heaviest, I see no reason why grayling may not be habituated to such a temperature-coolness being generally favourable to their existence. But see, the fog which had filled the valley and hid the mountains from our sight is clearing away, and I fear it will be a hot day. Before the sun becomes too bright is the best time for fishing in such a day as this. As soon as the fog is fairly off, the water flies will begin to appear, and fish to sport.

Phys.-I see the fog has already disappeared from the deep water in the meadow, where I suppose the warmth of the air from the considerable mass of the water is greater; and which is further removed from the hills sending down currents of cold air, from the mixture of which with the moist warm air above the river this phenomenon is produced. 
I see some yellow flies beginning to come out; they have already felt the influence of the warm air: and look! a fish has just risen opposite that bank, and has risen again: let us prepare our tackle.

Poiet.-What flies shall we employ.

HAL. - I recommend at least three; for the grayling lies deeper and is not so shy a fish as the trout; and, provided your link is fine, is not apt to be scared by the cast of flies on the water. The fineness of the link and of the guts to which your flies are attached, is a most essential point, and the clearer the stream the finer should be the tackle. I have known good fishermen foiled by using a gut of ordinary thickness, though their fly was of the right size and colour. Very slender transparent gut of the colour of the water is one of the most important causes of success in grayling fishing. Let me see your hook: I will select a fine stretcher. Now, for the lowest fly, use a yellow-bodied fly, with red hackle for legs, and landrail's wing: for the second, a blue dun, with dun body; and for the highest, the claret coloured body, with blue wings; 
and let your first dropper fly be about three feet from the stretcher and from the other dropper, and let the hanging link which attaches them be $3 \frac{1}{2}$ inches long.

Phys.-There are several fish rising: I shall throw at that opposite-he appears large.

HaL. - It is a trout and not a grayling.

Phys.-How do you know?

$\mathrm{H}_{\mathrm{AL}}$ - By his mode of rising. $\mathrm{He}$ is lying at the top of the water, taking the flies as they sail down by him, which a grayling scarcely ever does. He rises rapidly from the bottom or middle of the water, on the contrary - darting upwards, and having seized his fly, returns to his station. See, there a grayling has risen. I do not mean, however, that this habit is invariable; I have sometimes seen trout feed like grayling, and grayling like trout, but neither of these fish emits bubbles of air in rising, as dace and chub do.

Phys.-I have one! He has taken my blue dun and must be a small one, for he plays with no vigour.

$\mathrm{HAL}_{\text {. }}-\mathrm{He}$ is about $\frac{3}{4} \mathrm{lbs}$. - a fish of two 
years and a half old-very good for the table. I will land him if possible.

Phys.-There! He is off!

HAL.-This happens often with grayling: their mouths are tender, and unless the hook catches in the upper lip, which is rather thick, it is more than an equal chance that he escapes you.

Phys.-Here, I have another, that has taken the stretcher, which being a larger hook, I hope he may be held. He is likewise a larger fish-but how oddly he spins! This, I suppose, must be owing to his large back fin, by which the stream carries him

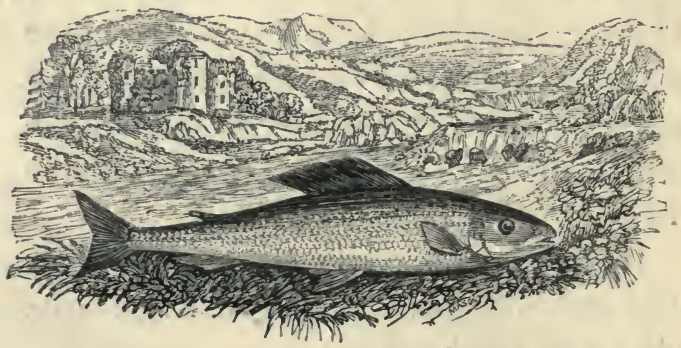


round. There he is: he has quite twisted my link; it would not be amiss to have swivels for this kind of fishing.

$\mathrm{H}_{\mathrm{AL}}$ - - It is a fish in good season,-dark above, fair below, and weighs, I should suppose, about $1 \frac{1}{4} \mathrm{lb}$.

\section{GRAYLING.}

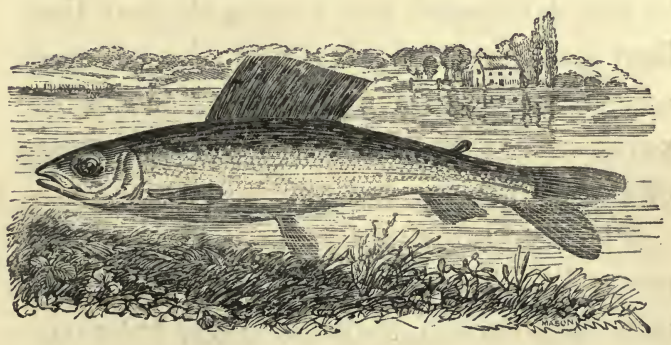

Phys.-As this is the first grayling I have seen of my own taking, I must measure, weigh, and examine him.

HaL.-We can do this hereafter. See, our fish barrel; he can be kept alive till a more convenient time of the day.

Phys.-I am disposed to gratify my curiosity immediately; and I think to acquire 
information is at least as interesting as catching fish. I shall kill him by a blow on the head. He, I suppose, is not worth crimping afterwards?

HAL.-Certainly not, at this time; and this is not necessary with a fish of this size, which ought to be fried; but if we catch a large grayling, approaching to $2 \mathrm{lbs}$. he shall be killed, crimped, and boiled, like our Denham trout; you will then find him excellent, and not inferior, in my thinking, to the best perch-more like the most exquisitely tasted of all our fish, the red mullet.

Phys.-Out of the water, this is a handsome fish, broader round the middle, and more hog-backed than the trout, but gracefully tapering towards the tail. The belly I see is silvery with yellow, and the pectoral, ventral and anal fins are almost goldcoloured; the back gray with small black spots, and the back fin beautifully coloured bright purple, with black and blue spots. It has likewise an agreeable odour; so that both from its colour and smell it does not seem undeserving the title given it by St. 
Ambrose, of the flower of fishes. It measures, I find, 14 inches in length; in girth $7 \frac{1}{2}$. It has 10 spines in the pectoral fin, 23 in the dorsal, 16 in the ventral, 14 in the anal, and 18 in the caudal.

HAL.--Now for its anatomy. Its stomach is very thick, not unlike that of a char or gillaroo trout, and contains flies, gravel, and larvæ, with their cases. The liver and bowels do not differ much from those of a trout; and the ovaria or roe, with eggs as large as mustard seed, are on each side the air bladder. Though a thicker fish, the grayling does not weigh much more than the trout in proportion to his length: the greater breadth of back is compensated by the more rapid tapering of tail, and a trout in very high season will sometimes equal in weight a grayling of the same length. The ova in this fish, and in the species generally, are very small at this time of the year; but in : the beginning of April, the season of their spawning, they become nearly as large as the ova of the trout-of the size of peppercorns. But I see, Poietes, your rod is in 
order and there are many fish rising in this large deep pool, some of which are large grayling. The blue dun is on in quantity, and there is both cloud and wind, which half an hour ago we had no right to expect. Let me advise you to use three flies of different shades of the dun: the stretcher, a pale blue with yellow body; the first dropper, a winged fly with dun body; and the third, a similar fly with dark body. There, you see; he rose and refused your stretcher -and again he has a second time refused it. I think the colour of the dubbing is too bright: try a winged fly for the stretcher with a greenish body. Good-he has taken it, and ought to be a large fish. Now we have him: he is at least sixteen inches long, and in good season. Ornither, I advise you to use the same kind of fly, and to put up your tackle precisely in the same way as Poietes has done.

Poiet.-How well they rise! At that moment I had two on my line: one of them is gone, but $\mathbf{I}$ hope $\mathbf{I}$ shall land the other.

HaL. - Fish with activity while the cloud 
lasts. I fear the sun is coming out, when it will be more difficult to take fish. I shall try the next pool, and I advise you to follow me and fish by turns,-passing each other, and taking different pools below, and so wend your way downwards, fishing wherever you see fish sporting. There is no better part of the river than that pool below you, and you cannot take a wrong direction. Immediately beyond Burrington Bridge you will find two excellent pools, and I advise you to go no farther down to-day. If you take a fish approaching 2 lbs. keep him alive in the fish barrel for crimping; the smaller fish you can kill, and carry with some rushes in your basket; we shall at least be able to send a dish of grayling to the patron of our sport at Downton.

\section{NOON.}

HaL. - Well, gentlemen, I hope you have been successful.

Poret.-We have had good sport; but I have been for some time reposing on this bank, and admiring the scene below. How N 2 
fine are these woods! How beautiful these banks! and the hills in the distance approach to the character of mountains; and the precipitous cliff which forms the summit of that distant elevation, looks like a diluvian monument, and as if it had been bared and torn by a deluge which it had stemmed.

HaL. - It is one of the Clee hills, and its termination is basaltic, and such rocks usually assume such forms. But though this spot is beautiful, to-morrow, I hope to show you a still more exquisite landscape,cliffs and woods, and gushing waters, of a character still more romantic. We will return to our inn by a shorter road; but tell me, have you caught a large fish amongst you and preserved him for crimping?

Poict.-We have preserved two fishes in the barrel, but I fear they are much below your proposed size.

HaL. - They are good fish, and of the average size of the large grayling in this stream-about $1 \frac{1}{2} \mathrm{lbs}$. but they will make a good variety placed in the middle of the fried fish. And how many have you caught altogether? 
Poiet.-I have basketed (to coin a word) three trout and six graylings.

Phys.-And I have taken seven graylings. I caught trout likewise, but not considering them in proper season, I returned them to the river: but Ornither has been the most successful-he has killed ten graylings.

HAL. - The trout is rarely good in this river-at least I never saw one that cut red, and yet I have taken them in July, when their external appearance was perfect and beautiful; but they have, to my taste, always a flabby and soft character of flesh, and at all seasons here are inferior for the table to grayling; yet they often attain a considerable size. There are few small fish in these streams, and I suppose the grayling, which are most numerous, deprive the trout of their proper share of the food, depending upon larvæ and flies.

Phys.-As we are walking through these meadows, pray give us some information as to the habits of the grayling, and his localities in England: I have been so much 
pleased with my sport, that I shall become, with St. Ambrose, a patron of the fish.

- HaL. - The habits of the grayling, like those of most other fish, are very simple. $\mathrm{He}$ is, I believe, to a certain extent, gregarious-more so than the trout, and less so than the perch, and the usual varieties of the carp species known in England. His form and appearance you have seen. He is as yet scarcely in his highest or most perfect season, which is in the end of November or beginning of December, when his back is very dark, almost black, and his belly and lower fins almost gold-coloured; but his brightness, like that of most other fishes, depends a good deal upon the nature of the water: and on the continent, I have seen fishes far more brilliantly coloured than in England-the lower part almost a bright orange, and the back fin approaching the colour of the damask rose, or rather of an anemoné. The grayling spawns in April, and sometimes as late as the beginning of May: the female is generally then followed by two or three males. She deposits her 
ova in the tails of sharp streams, and the males, rubbing against her, shed upon the ova the melt or seminal fluid. I do not know how long a time is required for the exclusion of the young ones; but in the end of July, or beginning of August, they are of the size of sprats, four or five inches long, and already sport merrily at a fly. Though I have often taken grayling in bad season, yet I never observed upon them the same kind of leech, or louse, which is so often found upon the trout; from which I conclude that they seldom or never hide themselves, or become torpid in the mud. The grayling hatched, I conclude, in May or June, become the same year, in September or October, nine or ten inches long, and weigh from half $a$ pound to ten ounces; and the year after they are from twelve to fifteen inches long, and weigh from three-quarters to a pound; and these two sizes, as you have seen, are the fish that most usually rise at the fly. The first size in this river is called shote, which is a Celtic word, I believe, applied likewise in the west of England to small 
trout. Of their growth after the second year I cannot speak, this must depend much on their food and place of residence. Marsigli says, they do not grow after the third year, and at this age, in Austria, they are sometimes a cubit long; but though I have fished much in that country, I never saw any so long. If they are taken into new and comparatively still water recently made, and when food is plenty, they grow very fast: under these circumstances, I have seen them above 3 lbs. In the Test, where, as I mentioned before, the grayling has been only recently introduced, they have sometimes been caught between 3 and $4 \mathrm{lbs}$.- in this river I never took one above 2 lbs. but I have heard of one being taken of $2 \frac{1}{2} \mathrm{lbs}$. The grayling is a rare fish in England, and has never been found in Scotland and Ireland (as Poietes observed before); and there are few rivers containing all the conditions necessary for their increase. I know of no grayling river farther west than the Avon, in Hampshire: they are found in some of the tributary streams of this river which rise 
in Wiltshire. I know of no river containing them on the north coast west of the Severn: there are very few only in the upper part of this river, and in the tributary streams which form it in North Wales. There are a few in the Wye and its tributary streams. In the Lug, which flows through the next valley, in. Herefordshire, many grayling are found. In the Dee, as I have said before, they are found, but are not common. In Derbyshire and Staffordshire, the Dove, the Wye, the Trent, and the Blithe, afford grayling; in Yorkshire, on the north coast, some of the tributary streams of the Ribble, the Erne, and the Wharf; and in the south of Yorkshire, the Humber, the Derwent, and its tributary streams, particularly the Rye. There may be some other localities of this fish unknown to me; but as I have fished much, and inquired much respecting the places where it is found, I think my information tolerably correct and complete.

Phys.-Is this fish to be fished for in spring?

HaL. - He is to be fished for at all times, 
for he is rarely so much out of season as to be a bad fish; and when there are flies on the water, will generally take them: but as the trout may be considered as a spring and summer fish, so the grayling may be considered as winter and autumnal fish.

Phys.-Of course the grayling is taken in spring with the same imitation of flies as the trout?

HaL. - The same. As far as flies are concerned, these two species feed alike; though I may say, generally, that the grayling prefers smaller flies, and the varieties of the ephemeræ or phryganeæ, of the smallest size, form their favourite food. Yet graylings do not refuse large flies; and in the Avon and Test, May flies, and even moths, are greedily taken in the summer by large grayling. Flies, likewise, that do not inhabit the water, but are blown from the land, are likewise good baits for grayling. There is no method more killing, for large grayling, than applying a grasshopper to the point of a leaded hook, the lead and shank of which are covered with green and yellow 
silk, to imitate the body of the animal. This mode of fishing is called sinking and drawing. I have seen it practised in this river with as much success as maggot fishing; and the fish taken were all of the largest size; the method being most successful in deep holes, where the bottom was not visible, which are the natural haunts of such fish. In the winter, grayling rise for an hour or two, in bright and tolerably warm weather; and, at this time, the smallest imitations of black or pale gnats that can be made, on the smallest sized hook, succeed best in taking them. In March, the dark-bodied willow fly may be regarded as the earliest fly; the imitation of which is made by a dark claret dubbing and a dun hackle, or four small starling's wing feathers. The blue dun comes on in the middle of the day in this month, and are imitated by dun hackles for wings and legs, and an olive dubbing for body. In mild weather, in morning and evening in this month, and through April, the green tail, or grannom, comes on in great quantities, and is well 
imitated by a hen pheasant's wing feather, a grey or red hackle for legs, and a dark peacock's harle, or dark hare's ear fur, for the body. The same kind of fly, of a larger size, with paler wings, kills well in the evening, through May or June. The imitation of a water insect called the spider fly, with a lead-coloured body and woodcock's wings, is said to be a killing bait, on this and other rivers, in the end of April and beginning of May; but I never happened to see it on the water. The dark alder fly, in May and June, is taken greedily by the fish: it is imitated by a dark-shaded pheasant's wing, black hackle for legs, and a peacock's harle, ribbed with red silk, for the body. At this season, and in July, imitations of the black and red palmer worms, which I believe are taken for black or brown, or red beetles or cockchaffers, kill well; and, in dark weather, there are usually very light duns on the water. In August, imitations of the house fly and blue bottle, and the red and black ant fly, are taken, and are particularly killing after floods in autumn, when great 
quantities of the fly are destroyed and washed down the river. In this month, in cloudy days, pale-blue duns often appear; and they are still more common in September. Throughout the summer and autumn, in fine calm evenings, a large dun fly, with a pale yellow body, is greedily taken by grayling after sunset; and the imitation of it is very killing. In the end of October, and through November, there is no fly fishing but in the middle of the day, when imitations of the smaller duns may be used with great success; and I have often seen the fish sport most, and fly fishing pursued with the greatest success, in bright sunshine, from twelve till half-past two o'clock, after severe frosts in the morning; and I once caught a very fine dish of fish on the 7th of November. It was in the year 1816; the summer and autumn had been peculiarly cold and wet, and, probably in consequence of this, the flies were in smaller quantity at their usual season, and there was a greater proportion later in the year.

Grayling, if you take your station by the 
side of a river, will rise nearer to you than trout, for they lie deeper, and therefore are not so much scared by an object on the bank; but they are more delicate in the choice of their flies than trout, and will much oftener rise and refuse the fly. Trout, from lying nearer the surface, are generally taken before grayling, where the water is slightly coloured, or after a flood: and in rain, trout usually rise better than grayling, though it sometimes happens, when great quantities of flies come out in rain, grayling, as well as trout, are taken with more certainty than at any other time; - the artificial fly, in such cases, looks like a wet fly, and allures even the grayling, that generally is more difficult to deceive than trout in the same river.

Phys.-As I was looking into a ditch coming down the river, which is connected with it, I saw a very large eel at the bottom, who appeared to me to be feeding on a small grayling:- are there many of this fish in the Teme, and do they breed here?

HAL. - There are many of this fish in the 
river; but to your question, do they breed here? I must answer in the negative. The problem of their generation is the most abstruse, and one of the most curious, in natural history; and though it occupied the attention of Aristotle, and has been taken up by most distinguished naturalists since his time, it is still unsolved.

Phys.-I thought there was no doubt on the subject. Lacepède, whose book is the only one I have read with attention, asserts, in the most unqualified way, that they are viviparous.

HAL. - I remember his assertion, but I looked in vain for proofs.

Phys.-I do not remember any facts brought forward on the subject; but tell us what you think upon it.

HAL. - I will tell you all I know, which is not much. This is certain, that there are two migrations of eels, - one up and one down rivers, one from and the other to the sea; the first in spring and summer, the second in autumn or early winter. The first of very small eels, which are sometimes 
not more than two or two and a half inches long; the second of large eels, which sometimes are three or four feet long, and which wieigh from 10 to 15 , or even $20 \mathrm{lbs}$. There is great reason to believe that all eels found in fresh water are the results of the first migration: they appear in millions in April and May, and sometimes continue to rise as late even as July and the beginning of August. I remember this was the case in Ireland, in 1823. It had been a cold backward summer, and when I was at Ballyshannon, about the end of July, the mouth of the river, which had been in flood all this month, under the fall, was blackened by millions of little eels, about as long as the finger, which were constantly urging their way up the moist rocks by the side of the fall. Thousands died, but their bodies remaining moist, served as the ladder for others to make their way; and I saw some ascending even perpendicular stones, making their road through wet moss, or adhering to some eels that had died in the attempt. Such is the energy of these little animals, 
that they continue to find their way, in immense numbers, to Loch Erne. The same thing happens at the fall of the Bann, and Loch Neagh is thus peopled by them: even the mighty Fall of Shaffausen does not prevent them from making their way to the Lake of Constance, where I have seen many very large eels.

Phys.-You have shown that some eels come from the sea, but I do not think the facts prove that all eels are derived from that source.

- HaL. - Pardon me-I have not concluded. There are eels in the Lake of Neufchatel, which communicates by a stream with the Rhine; but there are none in the Lake of Geneva, because the Rhone makes a subterraneous fall below Geneva; and though small eels can pass by moss or mount rocks, they cannot penetrate limestone rocks, or move against a rapid descending current of water, passing, as it were, through a pipe. Again: no eels mount the Danube from the Black Sea; and there are none found in the great extent of lakes, swamps and rivers commu- 
nicating with the Danube,-though some of these lakes and morasses are wonderfully fitted for them, and though they are found abundantly in the same countries, in lakes and rivers connected with the ocean and the Mediterranean. Yet, when brought into confined water in the Danube, they fatten and thrive there. As to the instinct which leads young eels to seek fresh water, it is difficult to reason:-probably they prefer warmth, and, swimming at the surface in the early summer, find the lighter water warmer, and likewise containing more insects, and so pursue the courses of fresh water, as the waters from the land, at this season, become warmer than those from the sea. Mr. J. Couch (Lin. Trans. tit. xiv. p. 70) says the little eels, according to his observation, are produced within reach of the tide, and climb round falls to reach fresh water from the sea. I have sometimes. seen them, in spring, swimming in immense shoals in the Atlantic, in Mount Bay, making their way to the mouths of small brooks and rivers. When the cold water from the 
autumnal flood begins to swell the rivers, this fish tries to return to the sea; but numbers of the smaller ones hide themselves during the winter in the mud, and many of them form, as it were, masses together. Various authors have recorded the migration of eels in a singular way,-such as Dr. Plot, who, in his History of Staffordshire, says they pass in the night, across meadows, from one pond to another: and Mr. Arderon (in Trans. Royal Soc.) gives a distinct account of small eels rising up the floodgates and posts of the water-works of the city of Norwich; and they made their way to the water above, though the boards were smooth planed, and five or six feet perpendicular. He says, when they first rose out of the water upon the dry board, they rested a little-which seemed to be till their slime was thrown out, and sufficiently glutinousand then they rose up the perpendicular ascent with the same facility as if they had been moving on a plane surface.-(Trans. Abr. vol. ix. p. 311.) There can, I think, be no doubt that they are assisted by their 
small scales, which, placed like those of serpents, must facilitate their progressive motion: these scales have been microscopically observed by Lewenhoeck.-(Phil. Trans. vol. iv.) Eels migrate from the salt water of different sizes, but I believe never when they are above a foot long-and the great mass of them are only from two and a half to four inches. They feed, grow, and fatten in fresh water. In small rivers they seldom become very large; but in large deep lakes they become as thick as a man's arm, or even leg; and all those of a considerable size attempt to return to the sea in October or November, probably when they experience the cold of the first autumnal rains. Those that are not of the largest size, as I said before, pass the winter in the deepest parts of the mud of rivers and lakes, and do not seem to eat much, and remain, I believe, almost torpid. Their increase is not certainly known in any given time, but must depend upon the quantity of their food: but it is probable they do not become of the largest size, from the small. 
est, in one or even two seasons; but this, as well as many other particulars, can only be ascertained by new observations and experiments. Block states, that they grow slowly, and mentions that some had been kept in the same pond for fifteen years. As very large eels, after having migrated, never return to the river again, they must (for it cannot be supposed that they all die immediately in the sea) remain in salt water; and there is great probability that they are then confounded with the conger, which is found of different colours and sizes-from the smallest to the largest -from a few ounces to one hundred pounds in weight. The colour of the conger is generally paler than that of the eel; but, in the Atlantic, it is said that pale congers are found on one side of the Wolf Rock; and dark ones on the other. The conger has breathing tubes, which are said not to be found in the other eel; but to determine this would require a more minute examination than has yet been made. Both the conger and common eel have fringes along the air bladder, which are probably the 
ovaria ; and Sir E. Home thinks them hermaphrodite; and that the seminal vessels are close to the kidneys; but this circumstance demands confirmation from new dissections, and some chemical researches upon the nature of the fringes and the supposed melt. If viviparous, and the fringes contain the ova, one mother must produce tens of thousands, the ova being remarkably small; and it appears more probable that they are oviparous, and that they deposit their ova in parts of the sea near deep basins, which remain warm in winter. This might be ascertained by experiment, particularly on the coasts of the Mediterranean. I cannot find that they haunt the Arctic ocean, which is probably of too low a temperature to suit their feelings or habits; and the Caspian and the Black Sea are probably without them, from their not being found in the, Volga or Danube: these, being shallow seas, are perhaps too cold for them in winter. From the time that small eels begin to migrate (April), it is probable that they are generated in winter; and the pregnant eels 
ought to be looked for in November, December, and January. I opened one in December, in which the fringes were abundant, but I did not examine them under the microscope, or chemically. I hope this curious problem will not remain much longer unsolved. 


\section{0 )}

\section{EIGHTH DAY.}

\section{Halieus-Poietes-Ornither- Physicus.}

SCENE-DOWNTON.

Poiet.-This is a beautiful day, and I think, for fishing, as well as for the enjoyment of the scenery, fner than yesterday. The wind blows from the south, and is balmy; and though a few clouds are collecting, they are not sufficiently dense to exclude the warmth of the sun, and, as honest fishermen, we ought to prefer his warmth to his light.

HaL. - I do not think, as the day advances, there will be any deficiency of light; and I shall not be .sorry for this, as it will enable you to see the grounds of Downton, and the distances in the landscape, to more advantage: nor will light interfere much 
with our sport in this valley, where, as you see, there is no want of shade.

Poret. - This spot is really very fine. The fall of water, the picturesque mill, the abrupt cliff, and the bank, covered with noble oaks, above the river, compose a scene such as I have rarely beheld in this island.

HaL. - We will wander a little longer through the walks. There you will enter a subterraneous passage in the rock beyond the mossy grotto. Behold, the castle, or mansion-house, clothed in beautiful vegetables, of which the red creeper is most distinct, rises above on the hill! After we have finished our walk and our fishing, I will, if you please, take you to the house and introduce you to its worthy master, whom to know is to love, and to whom all good anglers should be grateful, and who has a strong claim to a more extensive gratitude-that of his country and of societyby his scientific researches on vegetable nature, which are not merely curious, but useful, and which have already led to great improve- 
ments in our fruits and plants, and generally extended the popularity of horticulture.

Phys.-We shall be much obliged to you for the favour-provided always, you know it will not be an intrusion.

$\mathrm{H}_{\mathrm{AL}}$ - - Trust this to me. And now, as all circumstances are favourable, begin your fishing. I recommend to you that fine pool below the bridge, there are always grayling to be caught there-and I already see some rising.

Phys.-With what imitation of flies shall we fish?

HaL. - As yesterday; a yellow fly for your stretcher, and two duns for the droppers. There, you have a good fish. And now another-both graylings.

Phys.-I shall try the rapid at the top of this long large pool; I see several fish rising there.

HaL.-Do so. You will catch fish there -trout, but I fear no grayling.

Phys.-Why not?

HaL.- In that part of the stream the 
water is too rough for grayling, and they like to be nearer the deep water. Lower down in the same pool there are large grayling to be caught.

Phys.-You are in the right; the fish I have is a large trout - at least he is not much less than 2lbs. I have landed him, shall I keep him?

HaL.-As you please: he is as good as he ever was, or ever will be in this water.

Phys.-There are now more yellow flies out than I have seen before this season. They have appeared suddenly, as if sprung from that large alder. Though you gave us in a former conversation some account of the flies used in fishing, yet I hope you have not forgot your promise to favour us with some more details on this subject, which, both as connected with angling, and with a curious part of natural history, is very interesting.

HaL. - I wish it was in my power to give you information from my own observation, but I am sorry to say this has been very limited; and though the English are peculiarly the 
fly fishing nation, yet our philosophical anglers have not contributed much to this department of science, and what has been done is principally by foreigners, amongst whom Swammerdam, Reaumer, and above all De Geer, are pre-eminent. To attempt to collect and apply the knowledge collected by these celebrated men, would carry us far beyond the limits of a day's conversation, and as a great proportion of the insects that fly, walk, or crawl, are the food of fishes, a dissertation, or discourse on this subject, would be almost a general view of natural history. You know that frogs, crawfish, snails, earthworms, spiders, larvæ of every kind, millipedes, beetles, squillæ, moths, water flies, and land flies, are all eaten by trout; and I once heard the late Sir Joseph Banks say, that he found a large toad stuck in the throat of a trout; but as the skin of this animal is furnished with an exceedingly acrid secretion, it probably had been disgorged after being swallowed by a fish exceedingly hungry. But though I have found most of the insect tribes, and many small 
fishes, even of the most ravenous kind, as pike, in the stomachs of trout, it never happened to me to see a toad there. I might give you an account of the birth and life of frogs, which, with respect to their generation, resemble fish, and which, when first excluded. from the egg, may be considered in the tadpole state as fish; and you would not find their singular metamorphosis without interest. Or, I could detail to you, the true histories which naturalists have given of the habits of snails and earthworms, and of the loves of these apparently contemptible animals, from whom almost all sources of pleasure are cut off, and yet, who in their large hermaphrodite organs, and double intercourse, must, according to all analogy, possess decided advantage over most other beings of creation. Even the renewing or change of shell in the crawfish, when he falls an easy prey to fish in his soft state, is a curious subject not only for the physiologist, but likewise for the chemist. But on these points, I must request you to refer to writers in Natural History: yet I shall perform my 
promise, and say a few words on winged insects, which, in their origin and metamorphosis, offer the most extraordinary known miracles perhaps of terrestrial natures. You must be acquainted with the origin of our common house flies?

Phys.-We know that they spring from maggots, and that both the common and blue bottle fly deposit their ova in putrid animal matter, where the eggs are hatched and produce maggots, which, after feeding upon the decomposing animal material, gradually change, gain a hard or horny coat, seem as if entombed, and wait in a kind of apparent death or slumber, till they are mature for a new birth, when they burst their . coatings and appear in the character of novel beings - fitted to inhabit another element.

HaL. - The history of the birth and metamorphosis of all other winged insects is very similar, but with peculiarities dependent upon their organs, wants, and habits. You know the curious details with which we have been furnished by natural historians of bees 
and ants, which live in a kind of society. The ant flies, of which, as I mentioned to you, imitations are sometimes used by fishermen, were originally maggots, and lastly became furnished with wings - not however, passing the aurelia state for this last transformation.

Poiet.-I beg your pardon, but having lately read an account of these animals in the very interesting book, called "An Introduction to Entomology," I think I can correct you in one particular; that the maggot of the ant does assume the form of a chrysalis or pupa, before it becomes a winged animal.

HAL. - It is true that the immediate transition of the maggot is into a pupa, then into an ant, which is furnished with a kind of case from which the wings emerge for their perfect transformation into the fly or imago state. The males die soon after the sexual intercourse; the females when impregnated lose their wings, and either voluntarily or by force enter into society with neuter or working ants for the purpose of raising a new generation. 
Poiet.-You are perfectly right; and though it would be irrelevant to our present subject, I could almost wish for the sake of amusing our friends, that you would detail to us some other parts of the marvellous history of these wonderful animals, which if not so well authenticated, might be supposed a philosophical romance. Such as the neuter or working ants feeding each other and their offspring; the manner in which they make, defend, and repair their dwellings, provide their food, watch and attend to the female, and take care of her eggs; their extraordinary mode of acquiring and defending the aphides and cocci, which bear to them the same relation that cattle do to man, which are fed by them with so much care, and the milk of which forms so important a part of their food; the predatory excursions of a particular species to carry off pupa which they bring up slaves.

HAL.-To enter into any of the details of the history of insects in society, would carry us into an interminable, though interesting subject, which would soon lose all relation to, 
fly fishing; and I fear what I have to say, even on the winged insects connected with this amusement, will occupy too much of your time, for we have not more than an hour to devote to this object.

Porex.-Tell us what you please; we are attentive.

HaL. - The various individuals of the gryllus, or grasshopper tribe, spring from larvæ which do not differ much from the perfect insect, except in possessing no wings. The eggs are deposited in our meadows, and many species of this animal are gregarious, and the migrations in swarms are well known. The butterfly and moths as you know lay eggs which produce caterpillars, and these caterpillars, after feeding upon vegetable food, spin themselves-frame houses or beds, cocoons, in which they are transformed into aurelias, and from which they burst forth as perfect winged insects. The libellula, or dragon fly, the most voracious of the winged insect tribe, deposits her eggs in such a manner that the larvæ fall into the water, and after destroying and feeding upon almost 
all the aquatic insects found in this element, and changing their skins at various times, they emerge in their winged form the tyrants of the insect generations in the air. The gnats and tipulæ have a similar existence. The gnats, the female of which only is said by De Geer to bite man, or suck human blood, in Sweden, lays her eggs in a kind of little boat or cocoon of her own spinning. These eggs are hatched on the surface of the water, and produce the larvæ, which undergo another change into peculiar nymphæ, which still retain the power of swimming and moving, from which the perfect insect is produced during the summer heat. 'The flies which I mentioned to you in a former conversation, under the name of the grannom, or green tail, (see fig. 2,) are of the class phryganea, which includes all those water flies which have long antennæ, and wings something like those of moths, but usually veined and without powder. The yellow flies which you saw a short time since sporting on the banks of the river, are of this kind. The phryganeæ (see fig. 1, 2, 3, 
PHRYGANEA,

WITH THEIR IMITATIONS.
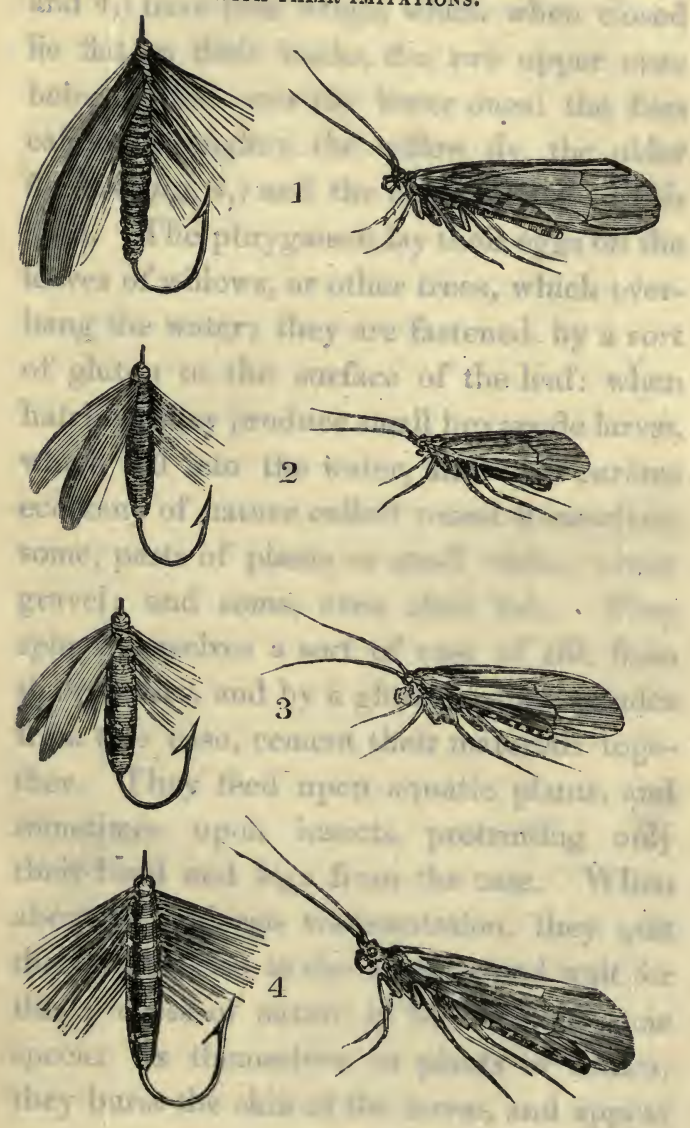
810

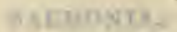

\section{1/Аอ МนЧ}

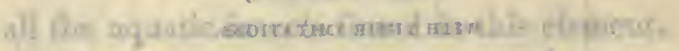

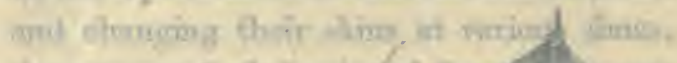

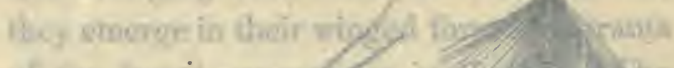

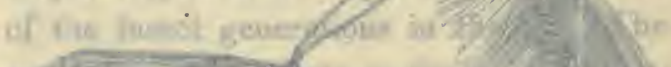

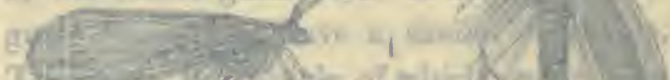

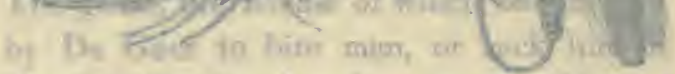

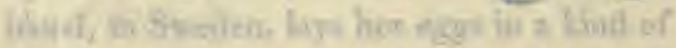

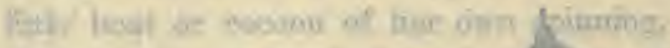

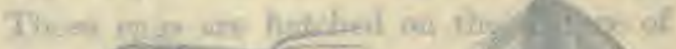

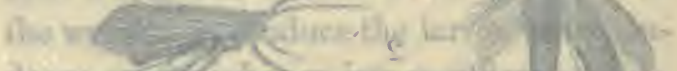
alezgo of

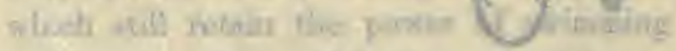

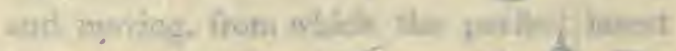

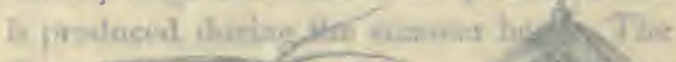
1)

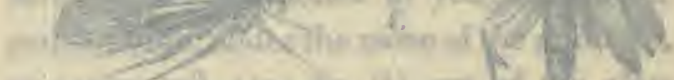

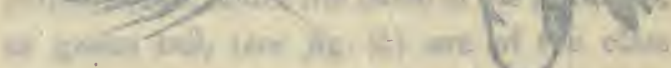

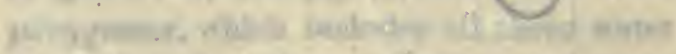

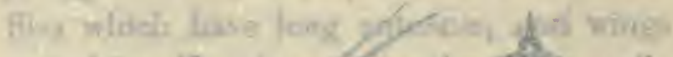

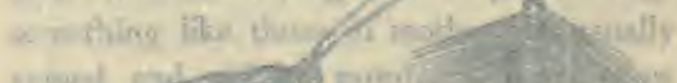

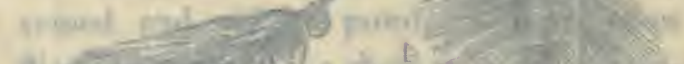

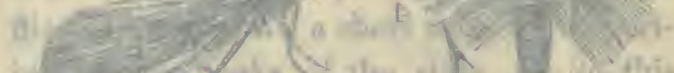

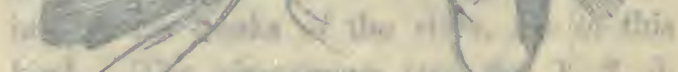

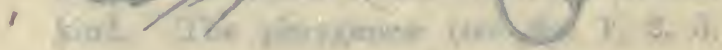


and 4, have four wings, which when closed lie flat on their backs, the two upper ones being folded over the lower ones: the flies called by anglers the willow fly, the alder fly, (see fig. 4,) and the dun cut, are of this kind. The phryganex lay their eggs on the leaves of willows, or other trees, which overhang the water; they are fastened by a sort of gluten to the surface of the leaf: when hatched, they produce small hexapode larvæ, which fall into the water, and by a curious economy of nature collect round themselves, some, parts of plants or small sticks; some; gravel; and some, even shell fish. They spin themselves a sort of case of silk from their bodies, and by a gluten, which exudes from this case, cement their materials together. They feed upon aquatic plants, and sometimes upon insects, protruding only their head and legs from the case. When about to undergo transmutation, they quit their cases, rise to the surface, and wait for this process of nature in the air; but some species fix themselves on plants or stones: they burst the skin of the larvæ, and appear 
perfect animals, male and female, fitted for the office of reproduction. In the early spring, the species which are called green tails, from the colour of the bags of eggs in the female, appear in the warm gleams of sunshine which happen in cloudy days, and they then cover the face of the water, and are greedily seized on by the fish. As the season advances they appear principally in the morning and evening. In the heat of summer the phryganer are almost nocturnal flies, and seem to have the habits. of moths: at this season, now, I should say, the few flies that appear are generally seen in the day-time. The ephemerce, another class' of flies peculiarly interesting to the fisherman, differ from the phryganeæ in carrying their wings perpendicularly on their backs, and in having long filaments or hairs in their tails. The March brown, (see fig. 8, the various shades of duns, (see fig. 5, 6, and 7,) which I described to you on a former occasion; the green (see fig. 9 and 10, ) and white May fly, the red spinner, (see fig. 11,) are all of the class ephemeræ. These flies 


\section{EPHEMER $Æ$,}

WITH THEIR IMITATIONS OR HOOKS.

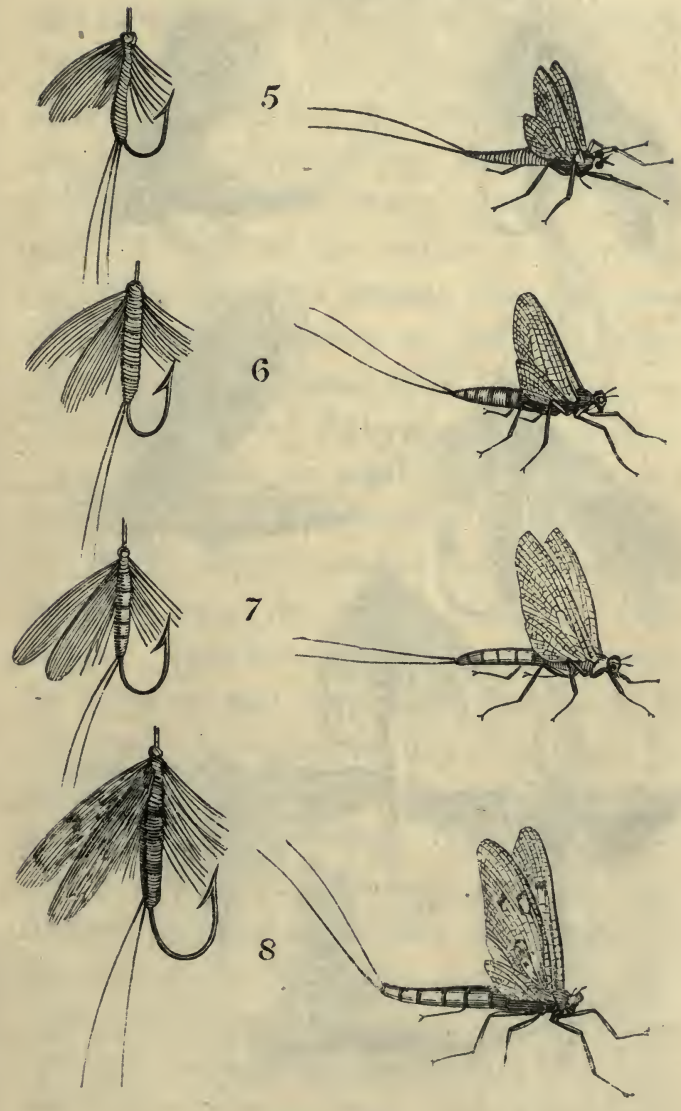




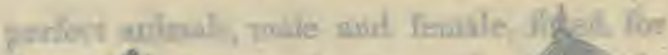

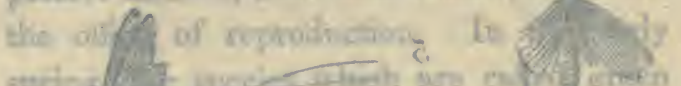

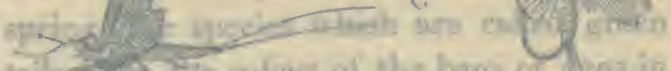

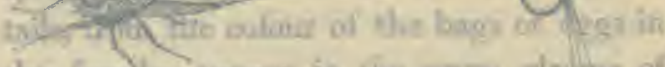

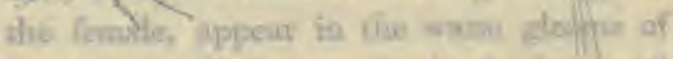

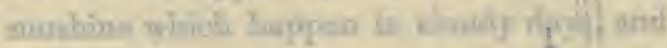

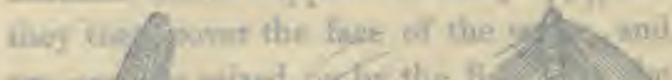

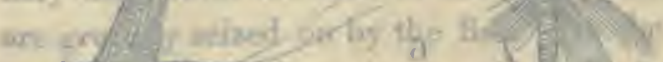

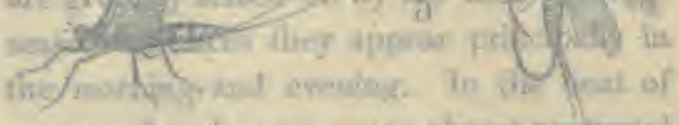

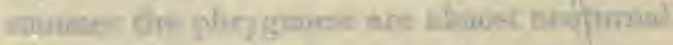

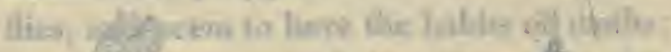
u. ay

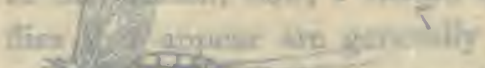

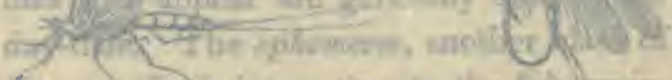

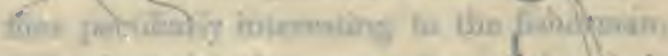

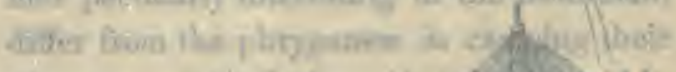

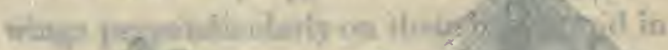

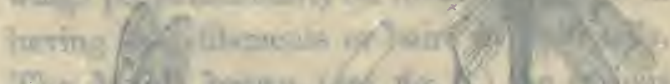

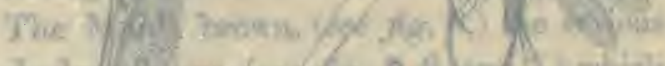

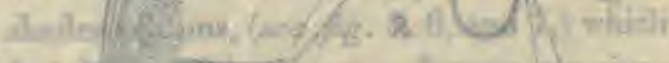

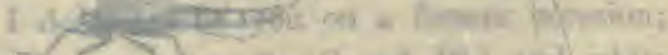

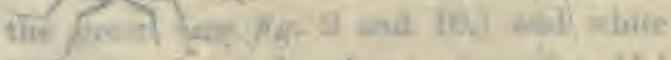

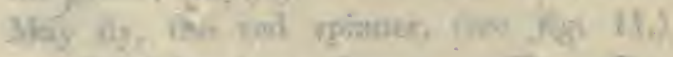

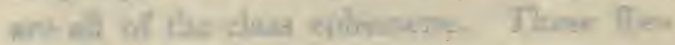




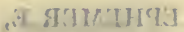

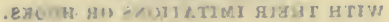

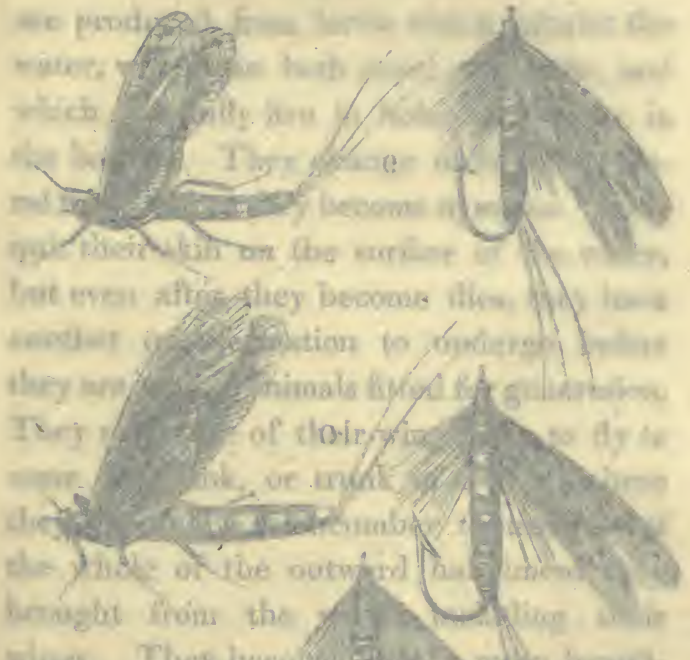
wines. They beew

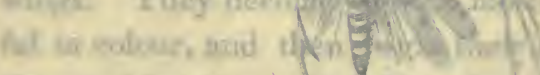

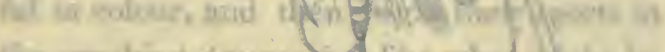

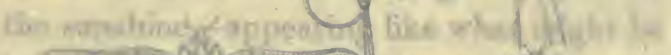
W.

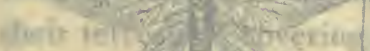

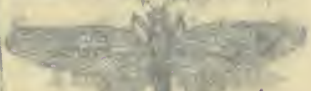

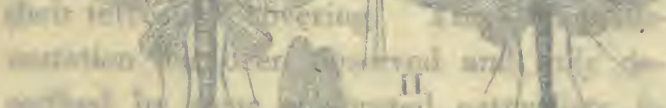

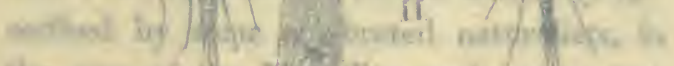

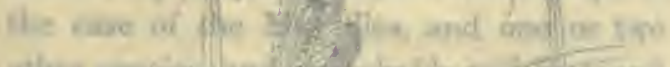

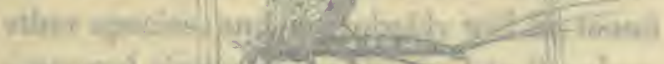

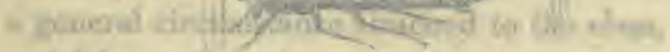

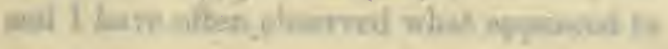


EPHEMER Æ,

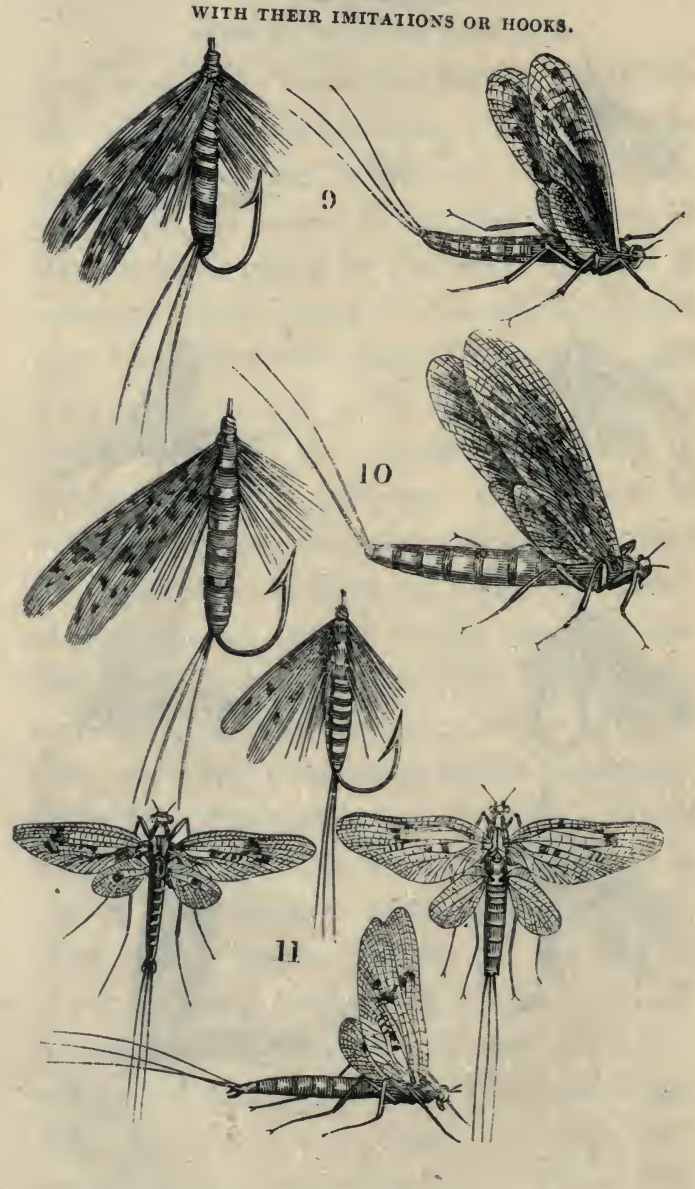


are produced from larvæ which inhabit the water, which can both crawl and swim, and which generally live in holes they make in the bottom. They change their coats several times before they become nymphæ. They quit their skin on the surface of the water, but even after they become flies, they have another transformation to undergo before they are perfect animals fitted for generation. They make use of their wings only to fly to some dry bank, or trunk of a tree, where they gradually disencumber themselves of the whole of the outward habiliment they brought from the water, including their wings. They become lighter, more beautiful in colour, and then begin their sports in the sunshine-appearing like what might be imagined of spirits freed from the weight of their terrestrial covering. This last transmutation has been observed and fully described by some celebrated naturalists, in the case of the May flies, and one or two other species, and it probably will be found a general circumstance attached to the class, and I have often observed what appeared to 
me to be the cast-off skins of the small species of ephemeræ on the banks of rivers and floating in the water. The green ephemera, or May fly, lays her eggs sitting on the water, which instantly sink to the bottom: and most of the duns, or small slenderwinged flies, do the same. The grey or glossy-winged May fly, commonly called the grey drake, performs regular motions in the air above the water, rising and falling, and sitting, as it were, for a moment on the surface, and rising again, at which time she is said to deposit her eggs. To attempt to describe all the variety of ephemeræ, which sport on the surface of the water at different times of the day, throughout the year, would be quite an endless labour. Some of them appear to live only a few hours, and none of them, I believe, more than a few days. In spring and autumn a new variety of these flies sometimes appears every day, or even in different parts of the same day. Of the beetle, or colyoptera genus, there are many varieties fed on by fishes. These insects, which are distinguished, as you know, by 
four wings, two husky-like shells above, and two slender and finer ones below, are bred from eggs, which they deposit in the ground, or in the excrement of animals, which, producing larvæ in the usual way, are converted into beetles, and these larvæ themselves are good bait for fish. The brown beetle, or cockchaffer, the fern fly, and the grey beetle, which are abundant in the meadows in the summer, are often blown into the water, and are the most common insects of this kind eaten by fishes. Whether the ditisci and hydrophili, the water beetles, are ever eaten by trout $I$ know not, but it is most probable. These singular animals are most usually found in stagnant waters; fitted for flying, swimming, diving, and walking, they are omnivorous, and usually fly from pool to pool in the evening. They deposit their eggs in the water, where their larvæ live, but to undergo transmutation into the beetle return to the land. But there is hardly any insect that flies, including the wasp, the hornet, the bee, and the butterfly, that does not become at some time the prey of fishes; 
and I have not the knowledge, or if I had, the time, to go through the lists of these interesting little animals; but of the family of one of them I must speak-the ichneumons, that deposit their eggs in caterpillars, or the larvæ of other flies, and which feed on the unfortunate animals on which they are hatched, and come out of its interior when dead, as if it had been their parent. To enter into the philosophy of this subject, and to study the organs and faculties of these various insect tribes, in their functions of respiration, nutrition, and reproduction, would be sufficient for the labour of a life. To know what has already been done would demand the close and studious application of a comprehensive mind; and to complete this department of science in all its parts, is probably almost above human powers, but much might be done if enlightened persons would follow the example of De Geer, Reaumer, and Huber, and study minutely the habits of particular tribes; and it is probable that physiology might be much advanced by minutely investigating the simplest 
forms of living beings, and that particularly with respect to the functions of generationa minute study of the modifications of which the forms of animals seem susceptible, particularly in the hymenopterous, or bee tribe, might lead to very important results.

Poret.-Even in a moral point of view, I think the analogies derived from the transformation of insects admit of some beautiful applications, which have not been neglected by pious entomologists. The three statesof the caterpillar, larva, and butterfly-have, since the time of the Greek poets, been applied to typify the human being-its terrestrial form, apparent death, and ultimate celestial destination; and it seems more extraordinary that a sordid and crawling worm should become a beautiful and active flythat an inhabitant of the dark and fotid dunghill should in an instant entirely change its form, rise into the blue air, and enjoy the sunbeams, - than that a being, whose pursuits here have been after an undying name, and whose purest happiness has been derived from the acquisition of intellectual 
power and finite knowledge, should rise hereafter into a state of being where immortality is no longer a name, and ascend to the source of Unbounded Power and Infinite Wisdom. 


\section{( 219$)$}

\section{NINTH DAY.}

\section{Halieus-Poietes-Ornither- Physicus.}

FISHING FOR HUCHO.

Scene-The Fall of the Traun, Upper Austria.

$$
\text { Time-July. }
$$

Poret.-This is a glorious scene! And the fall of this great and clear river, with its accompaniments of wood, rock, and snowclad mountain, would alone furnish matter for discussion and conversation for many days. This place is quite the paradise of a poetical angler; the only danger is, that of satiety with regard to sport; for these great grayling and trout are so little used to the artificial fly, that they take almost any thing moving on the top of the water. You see I have put on a salmon fly, and still the fish rise at it, though they never can have seen 
any thing like it before-and it is, in fact, not like any thing in nature.

$\mathrm{H}_{\mathrm{AL}}$ - - You are right, they never have seen any thing like it before; but, in its motion, it is like a large fly, and this is the season for large flies. The stone fly and the May fly, you see, occasionally drop upon the water, and the colour of your large fly is not unlike that of the stone fly; but if, instead of being here in the beginning of July, you had visited this spot, as I once did, in the beginning of June, you would have found more difficulty in catching grayling here, though not as much as in our English rivers - in the Test, the Derwent, or the Dove.

Poiet.-How could this be?

$\mathrm{H}_{\mathrm{AL}}$. - At this season the large flies had not yet appeared; the small blue dun was on the water, and I was obliged to use a fly the same as that which suits our spring and late autumnal fishing. The fish refused all large flies, but took greedily small ones; and, as usually happens when small flies are used, more fish escaped after being hooked 
than were taken; and these I found, the next day, were become as sagacious as our Dove or Test fish, and refused the artificial fly, though they greedily took the natural fly.

Phys.-These fish, then, have the same habits as our English salmons and trouts?

HaL. - The principle to which I have referred in two former conversations must be general, yet it has seemed to me that they lost this memory sooner than the fish of our English rivers, where fly fishing is common. This, however, may be fancy, yet I have referred it to a kind of hereditary disposition, which has been formed and transmitted from their progenitors.

Prys.-However strange it may appear, I can believe this. When the early voyagers discovered new islands, the birds upon them were quite tame, and easily killed by sticks and stones, being fearless of man; but they soon learned to know their enemy, and this newly acquired sagacity was possessed by their offspring, who had never seen a man. Wild and domesticated ducks are, in fact, 
from the same original type: it is only necessary to compare them, when hatched together under a hen, to be convinced of the principle of the hereditary transmission of habits,-the wild young ones instantly fly from man, the tame ones are indifferent to his presence.

Poiet.-No one can be less disposed than I am to limit the powers of living nature, or to doubt the capabilities of organized structures; but it does appear to me quite a dream, to suppose that a fish, pricked. by the hook of the artificial fly, should transmit a dread of it to its offspring, though he does not even long retain the memory of it himself.

HaL. - There are instances quite as extraordinary-but I will not dwell upon them, as I am not quite sure of the fact which we are discussing; I have made a guess only, and we must observe more minutely to establish it; it may be even as you suppose-a mere dream.

Poret.-I shall go and look at the fall: I am really satiated with sport; this is the 
twentieth fish I have taken in an hoúr, and it is a grayling of at least fifteen inches long; and there is a trout of eighteen, and several salmon trout, which look as if they had run from the sea.

HAL. - These salmon trout have run from a sea, but not from a salt sea; they are fish of the Traun See, as it is called by the Germans, or Traun Lake, which is emptied by this river.

Phys.-Tell us why they are so different from the river trout, or why there should be two species or varieties in the same water.

HaL.-Your question is a difficult one, and it has already been referred to in a former conversation; but I shall repeat what I stated before,-that qualities occasioned by food, peculiarities of water, \&c. are transmitted to the offspring, and produce varieties which retain their characters as long as they are exposed to the same circumstances, and only slowly lose them. Plenty of good food gives a silvery colour and round form to fish, and the offspring retain these characters. Feeding on shell-fish thickens the 
stomach, and in many generations, probably, the gillaroo trout becomes so distinct a variety, as to render it doubtful if it be not a distinct species. Even these smallest salmon trout have green backs, only black spots, and silvery bellies; from which it is evident that they are the offspring of lake trout, or lachs forelle, as it is called by the Germans; whilst the river trout, even when 4 or 5lbs. as we see in one of these fish, though in excellent season, have red spots. -But why that exclamation?

Poret.-What an immense fish! There he is!

HAL.-I see nothing.

Ponet-At the edge of the pool below the fall, I saw a fish, at least two or three feet long, rising with great violence in the water, as if in the pursuit of small fish; and at the same time I saw two or three minnows or bleaks jump out of the water. What fish is it?- a trout? It appeared to me too long and too slender for a trout, and had more the character of a pike;-yet it followed, and did not, like a pike, make a single dart. 
HaL.-I see him: it is neither a pike nor a trout; but a fish which I have been some time hoping and expecting to see here, below the fall-a salmo hucho, or huchen. I am delighted that you have an opportunity of seeing this curious fish, and of observing his habits. I hope we shall catch him.

Poiet.-Catch him! we have no tackle strong enough.

HaL.-I am surprised to hear a salmon fisher talk so: yet he is too large to take a fly, and must be trolled for. We must spin a bleak for him, or small fish, as we do for the trout of the Thames or the salmon of the Tay. Ornither, you understand the arrangement of this kind of tackle-look out in my book the strongest set of spinning hooks you can find, and supply them with a bleak; and whilst I am changing the reeI I will give you all the information (which, I am sorry to say, is not much) that $I$ have been able to collect respecting this fish from my own observation or the experience of others. The hucho is the most predatory fish of the salmo genus, and is made like an 
ill-fed trout, but longer and thicker. He has larger teeth, more spines in the pectoral fin, a thicker skin, a silvery belly, and dark spots only on the back and sides-I have never seen any on the fins. The ratio of his length to his girth is as 8 to 18 , or, in well-fed fish, as 9 to 20 ; and a fish, 18 inches long by 8 in girth, weighed 16215 grains. Of the spines in the fins, the anal has 9 , the caudal 20 , the ventral 9 , the dorsal 12, the pectoral 17: having numbered the spines in many, I give this as correct. The fleshy fin belonging to the genus is, I think, larger in this species than in any $\mathbf{I}$ have seen. Block, in his work on fishes, states that there are black spots on all the fins, with the exception of the anal, as a character of this fish: and Professor Wayner informs me he has seen huchos with this peculiarity; but, as I said before, I never saw any fish with spotted fins-yet I have examined those of the Danube, Save, Drave, Mur, and Izar: perhaps this is peculiar to some stream in Bavaria-yet the huchos in the collection at Munich have it 
not. The hucho is found in most rivers tributary to the Danube-in the Save and Laybach rivers always; yet the general opinion is, that they run from the Danube twice a year, in spring and autumn. I can answer for their migration in spring, having caught several in April, in streams connected with the Save and Laybach rivers, which had evidently come-from the still dead water into the clear running streams, for they had the winter leech, or louse of the trout, upon them: and $I$ have seen them of all sizes, in April, in the market at Laybach-from two feet long to six inches. It is the opinion of some naturalists, that it is only a fresh water fish; yet this I doubt, because it is never found beyond certain falls - as in the Traun, the Drave, and the Save; and, there can be no doubt, comes into these rivers from the Danube; and probably, in its largest state, is a fish of the Black Sea. Yet it can winter in fresh water; and probably many fish never return to the Black Sea, but fall back into the warmer waters of the great rivers, from which they migrate in spring,

$$
\text { Q } 2
$$


to seek a cooler temperature and to deposit their ova. The fishermen at Gratz say they spawn in the Mur, between March and May. In those I have caught at Laybach, which however were small ones; the ova were not sufficiently developed to admit of their spawning that spring. Marsigli says, that they spawn in the Danube in June. You have seen how violently they pursue their prey: I have never taken one without fish in his stomach; yet, when small, they will take a fly. In the Kleingraben, which is a feeder to the Laybach river, and where I have seen them of all sizes-from 3lbs. downwards - the little ones take a fly, but the large ones are too ravenous to care about so insignificant a morsel, and prey like the largest trout, often hunting in company, and chasing the small fish into the narrow and shallow streams, and then devouring them.But I see your tackle is ready. As a more experienced angler in this kind of fishing, you will allow me to try my fortune with this fish. I still see him feeding; but I must keep out of sight, for he has all the timidity 
peculiar to the salmo genus, and, if he catches sight of me, will certainly not run at the bait.

OrN.-You spin the bleak for him, I see, as for a great trout. $\mathrm{O}$ ! there! he has run at it-and you have missed him. What a fish! You surely were too quick, for he sprung out of the water at the bleak.

$\mathrm{H}_{\mathrm{AL}}$. - I was not too quick; but he rose just as the bleak was on the surface, and saw me; and now he is frightened, and gone down into the deep water. We must retire till we see him feeding again, which will be, I hope, in some minutes, for his violence shows he is not yet satisfied.

Poret. - I think I saw him moving in another part of the pool: it is now ten minutes since we saw him last.

HAL. - You are right; he is again on the feed, and in a place where we have a better chance of hooking him, as the water is deeper and in the shade. He has run again at the bleak, but only as it shone on the surface-but he is not frightened. Ah! he has taken it, and is floundering and struggling! He is a powerful fish. 
OrN.-He fights well, and runs towards the side where the rock is.

HAL. - Take the net and frighten him from that place, which is the only one where there is danger of losing him. He is clear now, and begins to tire, and in a few minutes more he will be exhausted.-Now land him.

Poiet.-A noble fish! But how like a trout-exactly like a sea trout in whiteness, and $I$ think in spots.

\section{SALMO HUCHO.}

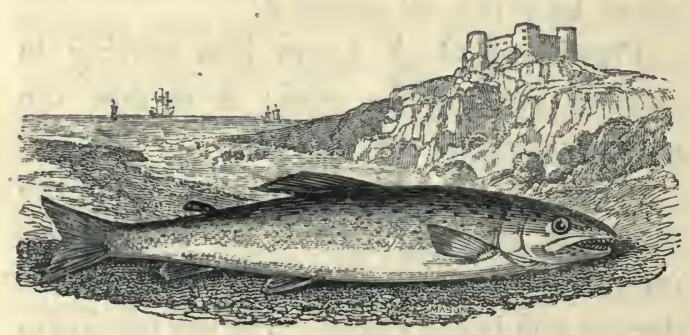

HaL. - He is much narrower, or less broad, as you would immediately discover if you had a sea trout here. But now we must 
try another pool, or the tail of this; that fish was not alone, and at the moment he took the bait, I think I saw the water move from the stir of another fish. Take your rod and fit your own tackle, Ornither; half the glory of catching this fish is yours, as you prepared the hooks. I see you are in earnest; the blood mounts in your face. Oh! oh! Ornither! you have pulled with too much violence, and broken your tackle. Alas! alas! the fish you hooked was the consort of mine: he will not take again.

OrN.-The gut was bad, for I do not think I struck too violently. What a loss! How hard, to let the first fish of the kind I ever angled for escape me!

HAL. - There are probably more: try again.

OrN.-Behold! the loss was more owing to the tackle than to my ardour; for the two end hooks only are gone, and you may see the gut worn.

HaL. - The thing is done, and is not worth comment. If you can, let the next fish that rises hook himself. When we are 
ardent, we are bad judges of the effort we make; and an angler, who could be cool with a new species of salmo, I should not envy. Now all is right again: try that pool. There is a fish-ay! and another, that runs at your bait; but they are small ones, not much more than twice as large as the bleak; yet they show their spirit, and though they cannot swallow it, they have torn. it. Put on another bleak. There! you have another . run.

Orn.-Ay, it is a small fish, not much more than a foot long; yet he fights well:

- HaL. - You have him, and I.will land him. I do not think such a fish a bad initiation into this kind of sport. He does not agitate so much as a larger one, and yet gratifies curiosity. There, we have him. A very beautiful fish; yet he has the leech, or louse, though his belly is quite white.

Orn.-This fish is so like a trout, that, had I caught him when alone, I should hardly have remarked his peculiarities; and I am not convinced that it is not a variety of the common trout, altered, in many genera- 
tions, by the predatory habits of his ancestors.

HaL.-How far the principle of change of character and transmission of such character to the offspring will apply, I shall not attempt to determine, and whether all the varieties of the salmo with teeth in their mouth may not have been produced from one original; yet this fish is now as distinct from the trout as the char or the umbla; and in Europe, it exists only below great falls in rivers connected with the Danube, and is never found in rivers of the same districts connected with the Rhine, Elbe, or which empty themselves into the Mediterranean; though trout are common in all these streams, and salmon and sea trout in those connected with the ocean. According to the descriptions of Pallas, it occurs in the rivers of Siberia, and probably exists in those that run into the Caspian; and it is remarkable, that it is not found where the eel is usual-at least this applies to all the tributary streams of the Danube, and, it is said, 
to the rivers of Siberia. Wherever I have seen it, there have been always coarse fishas chub, white fish, bleak, \&c. and rivers containing such fish are its natural haunts, for it requires abundance of food, and serves to convert these indifferent poor fish into a better kind of nourishment for man. We will now examine the interior of these fish. You see the stomach is larger than that of a trout, and both stomachs are full of small fish. In the larger one there is a chub, a grayling, a bleak, and two or three small carp. The skin you see is thick; the scales are smaller than those of a trout; it has no teeth on the palate, and the pectoral fin has four spines more, which, I think, enables it to turn with more rapidity. You will find at dinner, that fried, or roasted, he is good fish. His flesh is white, but not devoid of curd; and though rather softer than that of a trout, I have never observed in it that muddiness, or peculiar flavour, which sometimes occurs in trout, even in perfect season.

OrN.-I am so much pleased with my 
good fortune in catching this fish, that I shall try all day to-morrow with the bait, for more fish of the same kind.

HaL. - You may do so; but many of these fish cannot be caught; they migrate generally when the water is foul, and except in the spring and early summer, do not so readily run at the bait. I was once nearly a month seeking for one in rivers in which they are found, between the end of June and that of July, without being able to succeed in even seeing one alive; and as far as my information goes, the two places where there is most probability of taking them, is at Laybach and Ratisbon, in the tributary streams to the Sava, and in the Danube; and the best time in the first of these-situations, is in March and April, and in the second, in May. I am told, likewise, that the Izar, which runs by Munich, is a stream where these fish may be caught, when the water is clear: but I have never fished in this stream-it having been foul, either from rain, or the melting of the snows, whenever $I$ have been at Munich; but $I$ have seen in 
the fish-market at Munich, very large huchos. And late in the autumn, or in early spring, this river must be an interesting one to fish in, as the schill, or perca lucio perca, and three other species of perca are found in it - the zingil, the apron, and the perca scharatz-all fish of prey, and excellent food. I have eaten them, but never taken them; they are rare in European rivers, though not, like the hucho, peculiar to the tributary streams of the Danube. The schill is found likewise in the Sprey and in the Hungarian lakes; and according to Block, the zingil in the Rhone.

- Poiet.-I should like extremely to fish in the Izar: it is, I think, a new kind of pleasure to take a new kind of fish, even though it is not unknown to Natural Historians. But the most exquisite kind of angling in my opinion would be that of angling in a river never fished in by Europeans before; and I can scarcely imagine sport of a higher kind than that which involves a triple source of pleasure-that of catching a fish, of procuring good food for the table, and of making 
a discovery in Natural History, at the same time. Sir Joseph Banks, who was always a great amateur of angling, had often this kind of pleasure. And to Captain Franklin and Dr. Richardson, in their expedition to the Arctic Ocean, when they were almost starving, what a delightful circumstance it must have been, to have taken with a fly those large grayling of a new species, equally beautiful in their appearance, and good for the table!

HAL. -When a boy, I have felt an interest in sea fishing, for this reason-that there was a variety of fish; but the want of skill in the amusement-sinking a bait with a lead and pulling up a fish by main force, soon made me tired of it; and I have rarely fished in the sea since I have been a fly fisher, and then only with a reel and fine tackle from the rocks, which is at least as interesting an amusement as that of the Cockney fishermen who fish for roach and dace in the Thames, which I have tried twice in my life, but shall never try again.

Phys.-You are severe on Cockney fish- 
ermen, and, I suppose, would apply to them only, the observation of Dr. Johnson, which on a former occasion you would not allow to be just: "Angling is an amusement with a stick and a string; a worm at one end, and a fool at the other." And to yourself you would apply it with this change: " a fly at one end, and a philosopher at the other." Yet the pleasure of the Cockney Angler appears to me of much the same kind, and perhaps more continuous than yours; and he has the happiness of constant occupation and perpetual pursuit in as high a degree as you have; and if we were to look at the real - foundations of your pleasure, we should find them like most of the foundations of human happiness-vanity or folly. I shall never forget the impression made upon me some years ago, when I was standing on the pier at Donegal, watching the flowing of the tide, I saw a lame boy of fourteen or fifteen years old, very slightly clad, that some persons were attempting to stop in his progress along the pier, but he resisted them with his crutches, and halting along, threw himself 
from an elevation of five or six feet, with his crutches, and a little parcel of wooden boats that he carried under his arm, on the sand of the beach. He had to scramble or halt at least 100 yards, over hard rocks, before - he reached the water, and he several times fell down and cut his naked limbs on the bare stones. Being in the water he seemed in an extasy, and immediately put his boats in sailing order and was perfectly inattentive to the counsel and warning of the spectators, who shouted to him that he would be drowned. His whole attention was absorbed by his boats. He had formed an idea that one should outsail the others, and when this boat was foremost he was in delight; when any one of the others got beyond it he howled with grief; and once I saw him throw his crutch at one of the unfavoured boats. The tide came in rapidly-he lost his crutches, and would have been drowned but for the care of some of the spectators: but he was wholly inattentive to any thing save his boats. He is said to be quite insane and perfectly ungovernable, and will 
not live in a house, nor wear any clothes, and his whole life is spent in this one businessmaking and managing a fleet of wooden boats, of which he is sole admiral. How near this mad youth is to a genius, a hero, or to an angler, who injures his health and risks his life by going into the water as high as his middle, in the hope of catching a fish which he sees rise, though he already has a pannier full.

HaL.-Or a statesman, working by all means, fair and foul, to obtain a blue riband; or a fox-hunter, risking his neck to see the hounds destroy an animal which he preserves to be destroyed, and which is good for nothing. $\mathrm{Or}$ an aged licentious voluptuary, using all the powers of a high and cultivated intellect to destroy the innocence of a beautiful virgin-for a transient gratification to render lier miserable, and by making a flaw in an inestimable and brilliant gem, utterly to destroy its value.

Phys. - You might go on and give almost all the objects of pursuit of rational beings, as they are called. But to return to your 
favourite pursuit, I wonder that with your passion for the amusement of angling, you have never made an expedition in one of our whalers-with Captain Scoresby for instance: you would then have engaged in a sport of a new kind.

HAL. - I should like much to see a whale taken, but I do not think the sight worth the dangers and privations of such a voyage. It would only be an amusing sight and not an enterprize, unless indeed you yourself employed the harpoon; and after all it must be a tedious operation, that of watching the sinking and rising of a fish obedient to a natural instinct, which in this instance is the cause of his death.

\section{Poiet.-How?}

HAL. - The whale, having no air bladder, can sink to the lowest depths of the ocean, and mistaking the harpoon for the teeth of a sword fish or a shark, he instantly descends, this being his manner of freeing himself from these enemies, who cannot bear the pressure of a deep ocean, and from ascending and descending in small space, he 
puts himself in the power of the whaler; whereas, if he knew his force, and was to swim on the surface in a straight line, he would easily break or destroy the machinery by which he is arrested, as easily as a salmon breaks the single gut of a fisher when his reel is entangled.

Poiet.-My amusement in such a voyage would be to look for the kraken and the sea snake.

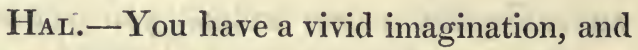
might see them.

Poret.-Then you do not believe in the existence of these wonderful animals?

$\mathrm{H}_{\mathrm{AL}}$. - No more than $\mathrm{I}$ do in that of the merman, or mermaid.

Point.-Yet we have histories, which seem authentic, of the appearance of these monsters, and there are not wanting persons who assert that they have seen the mermaid even in these islands.

HAL.-I disbelieve the authenticity of these stories. I do not mean to deny the existence of large marine animals having analogies to the serpent, the conger we know 
is such an animal: I have seen one nearly ten feet long, and there may be longer ones, but such animals do not come to the surface. The only sea snake which has been examined by naturalists, turned out to be a putrid species of shark-the squálus maximus. Yet all the newspapers gave accounts of this as a real animal, and endowed it with feet, which do not belong to serpents. And the sea snakes seen by American and Norwegian Captains, have, I think, generally been a company of porpoises, the rising and sinking of which in lines would give somewhat the appearance of the coils of a snake. The . kraken, or island fish, is still more imaginary. I have myself seen immense numbers of enormous urtica marina, or blubbers, in the north seas, and in some of the Norwegian fiords, or inland bays, and often these beautiful animals give colour to the water; but it is exceedingly improbable. that an animal of this genus should ever be of the size, even of the whale; its soft materials are little fitted for locomotion, and such an animal would be easily destroyed by every kind of fish. 
Hands and a finny tail are entirely contrary to the analogy of nature, and I disbelieve the mermaid upon philosophical principles. The dugong and manatee are the only animals combining the functions of the mammalia with some of the characters of fishes, that can be imagined even as a link in this part of the order of nature. Many of these stories have been founded upon the longhaired seal seen at a distance, and others on the appearance of the common seal under particular circumstances of light and shade, and some on still more singular circumstances. A worthy baronet, remarkable for his benevolent views and active spirit, has propagated a story of this kind, and he seems to claim for his native country the honour of possessing this extraordinary animal; but the mermaid of Caithness was certainly a gentleman, who happened to be travelling on that wild shore, and who was seen bathing by some young ladies at so great a distance, that not only genus but gender was mistaken. I am acquainted with hun, and have had the story from his own 
mouth. He is a young man, fond of geological pursuits, and one day in the middle of August, having fatigued and heated himself by climbing a rock to examine a particular appearance of granite, gave his clothes to his Highland guide, who was taking care of his poney and descended to the sea. The sun was just setting, and he amused himself for some time by swimming from rock to rock, and having unclipped hair and no cap, he sometimes threw aside his locks, and wrung the water from them on the rocks. He happened the year after to be at Harrowgate, and was sitting at table with two young ladies from Caithness, who were relating to a wondering audience the story of the mermaid they had seen, which had already been published in the newspapers: they described her as she usually is described by poets, as a beautiful animal, with remarkably fair skin, and long green hair. The young gentleman took the liberty, as most of the rest of the company did, to put a few questions to the elder of the two ladiessuch as, on what day and precisely where 
this singular phenomenon had appeared. She had noted down, not merely the day, but the hour and minute, and produced a map of the place. Our bather referred to his journal, and showed that a human animal was swimming in the very spot at that very time, who had some of the characters ascribed to the mermaid, but who laid no claim to others, particularly the green hair and fishes tail; but being rather sallow in the face, was glad to have such testimony to the colour of his body beneath his garments.

Poiet.-But I do not understand upon what philosophical principles you deny the existence of the mermaid. We are not necessarily acquainted with all the animals that inhabit the bottom of the sea; and I cannot help thinking there must have been some foundation for the fable of the Tritons and Nereids.

HaL. - Ay; and of the ocean divinities, Neptune and Amphitrite!

Poret.-Now I think you are prejudiced. HaL. - I remember the worthy Baronet, whom $I$ just now mentioned, on some one 
praising the late Sir Joseph Banks very highly, said, "Sir Joseph was an excellent man-but he had his prejudices." What were they? said my friend. "Why, he did not believe in the mermaid." Pray still consider me as the Baronet did Sir Joseph -prejudiced on this subject.

OrN.-But give us some reasons for the impossibility of the existence of this animal.

HaL.-Nay, I did not say impossibility; I am too much of the school of Izaac Walton to talk of impossibility. It doubtless might please God to make a mermaid; but I do not believe God ever did make a mermaid.

OrN.-And why?

HAL. - Because wisdom and order are found in all his works, and the parts of animals are always in harmony with each other, and always adapted to certain ends consistent with the analogy of nature; and a human head, human hands, and human mammæ, are wholly inconsistent with a fish's tail. The human head is adapted for an erect posture, and in such a posture an animal with a fish's tail could not swim; and a 
creature with lungs must be on the surface several times in a day-and the sea is an inconvenient breathing place; and hands are instruments of manufacture-and the depths of the ocean are little fitted for fabricating that mirror which our old prints gave to the mermaid. Such an animal, if created, could not long exist; and, with scarce any locomotive powers, would be the prey of ither fishes formed in a manner more suited to their element. I have seen a most absurd fabrication of a mermaid exposed as a show in London, said to have been found in the Chinese seas, and bought for a large sum of money. The head and bust, of two different apes, were fastened to the lower part of a kipper salmon, which had the - fleshy fin, and all the distinct characters, of the salmo salar.

Ors.-And yet there were people who believed this to be a real animal.

HaL. - It was insisted on to prove the truth of the Caithness story. But what is there which people will not believe?

PoIEt.-In listening to your conversation 
we have forgotten our angling, and have lost some moments of fine cloudy weather.

HAL. - I thought you were tired of catching trouts and graylings, and I therefore did not urge you to continue your fly fishing; and this part of the river does not contain so many grayling as the pools above-but there are good trout, and it is possible there may be huchos. Let me recommend to you to put on minnow tackle-that tackle with the fine small hooks; and, as we have minnows and bleaks, you may perhaps hook trout, or even huchos; and in half an hour our fish dinner at the inn will be ready. I shall return there, to see that all is right, and shall expect you there when you have finished your fishing.

\footnotetext{
[They all meet in the dining-room of the inn.]
}

HaL. - Well, what sort of sport have you had since I left you?

Poiex.-We have each caught a trout and two large chubs, and have had two or 
three runs besides-but we saw no huchos; and though several large grayling rose in one of the streams, and we tried to catch them by spinning the minnow in every possible way, yet they took no notice of our bait.

HAL. - This is usually the case. I have heard of anglers who have taken grayling with minnows, but this is a rare occurrence, and never happened to me. Your dinner, I dare say, is now ready; and you know it is a dinner entirely of the genus salmo, with vegetables and fruit. You have hucho from the Traun, and char from Aussee, and trout from the Traun See, that were brought alive to the inn, and have only just been killed and crimped, and are now boiling in salt and water; and you have likewise grayling and laverets from the Traun See, which are equally fresh, and which will be fried.

Phys.-I think, in this part of the continent, the art of carrying and keeping fish is better understood than in England. Every inn has a box containing grayling, trout, carp, or char, into which water from a spring 
runs; and no one thinks of carrying or sending dead fish for a dinner. A fish barrel full of cool water, which is replenished at every fresh source amongst these mountains, is carried on the shoulders of the fisherman. And the fish, when confined in wells, are fed with bullock's liver, cut into fine pieces, so that they are often in better season in the tank or stew than when they were taken. I have seen trout, grayling, and char even, feed voraciously, and take their food almost from the hand. These methods of carrying and preserving fish have, I believe, been adopted from the monastic establishments. At Admondt, in Styria, attached to the magnificent monastery of that name, are abundant ponds and reservoirs for every species of fresh water fish; and the char, grayling and trout are preserved in different waters-covered, enclosed, and under lock and key.

Poret.-I admire in this country not only the mode of preserving, carrying, and dressing fish, but I am delighted, generally, with the habits of life of the peasants, and with 
their manners. It is a country in which I should like to live; the scenery is so beautiful, the people so amiable and good-natured, and their attentions to strangers so marked by courtesy and disinterestedness.

Phys.-They appear to me very amiable and good; but all classes seem little instructed.

Poict. - There are few philosophers amongst them, certainly; but they appear very happy, and

Where ignorance is bliss, 'tis folly to be wise.

We have neither seen nor heard of any instances of crime since we have been here. They fear their God, love their sovereign, are obedient to the laws, and seem perfectly contented. I know you would contrast them with the active and educated peasantry of the manufacturing districts of England; but I believe they are much happier, and I am sure they are generally better.

Phys.-I doubt this: the sphere of enjoyment, as well as of benevolence, is enlarged by education. 
Poiet.-I am sorry to say I think the system carried too far in England. God forbid that any useful light should be extinguished! Let persons who wish for education receive it; but it appears to me that, in the great cities in England, it is, as it were, forced upon the population; and that sciences, which the lower classes can only very superficially acquire, are presented to them; in consequence of which they often become idle and conceited, and above their usual laborious occupations. 'The unripe fruit of the tree of knowledge is, I believe, always bitter or sour; and scepticism and discontent-sickness of the mind-are often the results of devouring it.

HAL.--Surely you cannot have a more religious, moral, or more improved population than that of Scotland?

Poret.-Precisely so. In Scotland, education is not forced upon the people-it is sought for, and it is connected with their forms of faith, acquired in the bosoms of their families, and generally pursued with a distinct object of prudence or interest: nor 
is that kind of education wanting in this country.

Phys.-Where a book is rarely seen, a newspaper never.

Poiet.-Pardon me-there is not a cottage without a prayer book; and I am not sorry that these innocent and happy men are not made active and tumultuous subjects of King Press, whom I consider as the most capricious, depraved and unprincipled tyrant that ever existed in England. Depraved-for it is to be bought by great wealth; capricious - because it sometimes follows, and sometimes forms, the voice of the lowest mob; and unprincipled-because, when its interests are concerned, it sets at defiance private feeling and private character, and neither regards their virtue, dignity, or purity.

HaL.-My friends, you are growing warm. I know you differ essentially on this subject; but surely you will allow that the full liberty of the press, even though it sometimes degenerates into licentiousness, and though it may sometimes be improperly used by the 
influence of wealth, power, or private favour, is yet highly advantageous, and even essential to the existence of a free country; and, useful as it may be to the population, it is still more useful to the government, to whom, as expressing the voice of the people, though not always vox Dei, it may be regarded as oracular or prophetic.-But let us change our conversation, which is neither in time nor place.

Phys.-The char* is a most beautiful and excellent fish, and is, of course, a fish of prey. Is he not an object of sport to the angler?

HaL.-They generally haunt deep cool lakes, and are seldom found at the surface till late in the autumn. When they are at the surface they will, however, take either fly or minnow. I have known some caught in both these ways; and have myself taken a char, even in summer, in one of those beautiful, small, deep lakes in the Upper Tyrol, near Nazereit; but it was where a

* Sabling of the Germans. 
cool stream entered from the mountain; and the fish did not rise, but swallowed the artificial fly under water. I have fished for them in many lakes, without success, both in England and Scotland, and also amongst the Alps; and I am told the only sure way of taking them is by sinking a line with a bullet, and a hook having a live minnow attached to it, in the deep water which they usually haunt; and in this way, likewise, I have no doubt the umbla, or ombre chevalier, might be taken.

Poiet.-I have never happened to see this fish.

$\mathrm{H}_{\mathrm{AL}}$. - It is very like a char in form, but has no spots, and a white and silvery belly. On the table, its flesh cuts white or cream colour, and it is exceedingly like char in flavour.

Poiet.-Is it found in this country?

HaL. - From some descriptions I have heard of certain species of the salmo found in the Maun See, Traun See, and Leopoldstadt See, I think it is. Block says, that it is peculiar to the lakes of Geneva and Neuf- 
chatel; but this, I am sure, is not true; I have myself eaten them from the lake of Bourget, in Savoy; and I dare say they exist in other deep waters of a like character amongst the Alps. It is a fish closely allied to the char, and congenerous both in form and habits.

Phys.-You mentioned, among the fish for dinner, the laveret: I never heard of this fish before.

HaL. - It is a fish known in England by the name of shelley, or fresh water herring; in Wales by that of guineard; in Ireland. by that of pollan; and in Scotland by that of vengis. In colour it is most like a grayling, but with broader and larger scales: it is common in the large lakes of most Alpine countries, and is known at Geneva by the name of ferra; and I believe that the salmo ceruleus, or wartmaune of Block, or the gang fish, of the lake of Constance, from a comparison that I made of it with the ferra, is a variety of the same fish. It sometimes is as large as $2 \mathrm{lbs} . ;$ and when quite fresh, and 
well fried or broiled, is an exceedingly good fish, and carves like a grayling.

Poret.-Is this fish ever taken with the line?

HaL. - I believe only with nets. It feeds on vegetables; and in the stomachs of those I have opened, I have never found either flies or small fishes.

AT TABLE.

Phys.-Your fish are all excellent, but I prefer the char, which I think is even better than the best fresh salmon I ever tasted.

- HaL. - At Lintz, on the Danube, I could have given you a fish dinner of a different description, which you might have liked as a variety. The four kinds of perch, the spiegil carpfen, and the siluris glanis; all good fish, and which I am sorry we have not in England, where I doubt not they might be easily naturalized, and where they would form an admirable addition to the table in inland counties. Since England 
has become Protestant, the cultivation of fresh water fish has been much neglected. The burbot, or lotte, which already exists in some of the streams tributary to the Trent, and which is a most admirable fish, might be diffused without much difficulty; and nothing could be more easy than to naturalize the spiegil carpfen and siluris; and I see no reason why the perca lucio perca and zingil should not succeed in some of our clear lakes and ponds, which abound in coarse fish. The new Zoological Society, I hope, will attempt.something of this kind; and it will be a better object than introducing birds and beasts of prey-though I have no objection to any sources of rational amusement or philosophical curiosity. But the time for our parting is almost arrived.Let us drink a glass each of this old wine of the Danube to our next happy meeting, and go and take a last look at the Fall of Traun whilst our carriages are preparing.

[They walk to the rock above the Fall of the Traun.] 
$\mathrm{HAL}_{\mathrm{L}}$-See, the cataract is now in great beauty; the river above is coloured by the setting sun, and the glow of the rosy light on the upper stream is beautifully and wonderfully contrasted with the tints of the cataract below. Have you ever seen any thing so fine?

PoIEt.-The lights are beautiful; but I have certainly seen a finer combination of features in the Fall of the Velino, at Terni, though that water is not clear; but, even with this defect, it is certainly the most perfect of European falls. This Cascade of the Traun, though not so elevated as that of Terni, and not so large as that of Schaffhausen, yet, from its perfect clearness and the harmony of the surrounding objects, ranks high, as to picturesque effect, amongst the waterfalls of Europe ; and the wonderful transparency of its pale-green water gives it a peculiar charm in my eyes, enhanced as it is now by the light of the glowing western sky; and the tints of the quadrant iris on its spray are not brighter than those of its streams and foam. 
OrN.-We have now followed this water at least thirty miles, and wherever we have seen it, it has always displayed the same characters of clearness and rapidity - of green stream and white foam; and we have traced it from the snowy mountains of Styria to the plains of Upper Austria, where it serves to purify the darker Danube. How has it preserved its transparency, though so many of its tributary streams have been foul, either from the thunder storm or from the sudden melting of snows?

HAL.-The three small lakes and the two larger ones, which are in fact its reservoirs, are the cause of this. The Grundel see furnishes its principal stream, and this lake is fed by two others - Cammer see and Langen see; and the tributary streams, which unite at Aussee, from Alten Aussee and Oden see, though one is blue and the other is yellow, yet combine to give a tint which is nearly the same as that from the stream of the Grundel see, and which the river retains throughout its course. Yet I have seen even this river very foul, but only 
in a part of its course, below Ischel. I was once at that place, when the thunder storm of a night having washed the dust of the roads into the river, it was extremely turbid from Ischel to the Traun see. It rendered the upper part of this large lake coloured; but notwithstanding this, the river came from the lower part of it perfectly clear, and I caught fish in it there with a fly, which at its entrance into the lake was quite impossible.

Poiet.-You, Halieus, must certainly have considered the causes which produce the colours of waters. The streams of our own island are of a very different colour from these mountain rivers, and why should the same element or substance assume such a variety of tints.

HaL. - I certainly have often thought upon the subject, and I have made some observations and one experiment in relation to it. I will give you my opinion, with pleasure, and as far as I know, they have not been brought forward in any of the works on the properties of water, or on its 
consideration as a chemical element. The purest water with which we are acquainted, is undoubtedly that which falls from the atmosphere. Having touched air alone, it can contain nothing but what it gains from the atmosphere, and it is distilled without the chance of those impurities which may exist in the vessels used in an artificial operation. We cannot well examine the water precipitated from the atmosphere as rain without collecting it in vessels, and all artificial contact gives more or less of contamination; but in snow, melted by the sun beams, that has fallen on glaciers, themselves formed from frozen snow, water may be regarded as in its state of greatest purity. Congelation expels both salts and air from water, whether existing below, or formed in the atmosphere; and in the high and uninhabited regions of glaciers, there can scarcely be any substances to contaminate-removed from animal and vegetable life, they are even above the mineral kingdom; and though there are instances in which the rudest kind of vegetation (forms of the fungus or mucor kind) is even found 
upon snows, yet this is a rare occurrence; and red snow, which is occasioned by it, is an extraordinary and not a common phenomenon towards the pole, and on the highest. mountains of the globe. Having examined the water formed from melted snows on glaciers in different parts of the Alps, and having always found it of the same quality, I shall consider it as pure water, and describe its characters. Its colour, when it has any depth, or when a mass of it is seen through, is bright blue; and, according to its greater or less depth of substance, it has more or less of this colour: as its insipidity and its other physical qualities are not at this moment objects of your inquiry, I shall not dwell upon them. In general in examining lakes and masses of water in high mountains, their colour is of the same bright azure. And Captain Parry states, that the water on the Polar ice has the same beautiful tint. When vegetables grow in lakes, the colour becomes nearer sea green, and as the quantity of impregnation from their decay increases-greener, yellowish green, and at 
length, when the vegetable extract is large in quantity-as in countries where peat is found-yellow, and even brown. To mention instances, the Lake of Geneva, fed from sources (particularly the higher Rhone,) formed from melting snow, is blue; and the Rhone pours from it, dyed of the deepest azure, and retains partially this colour till it is joined by the Soane, which gives to it a greener hue. The Lake of Morat, on the contrary, which is fed from a lower country, and from less pure sources, is grass green. And there is an illustrative instance in some small lakes fed from the same source, in the road from Inspruck to Stutgard, which I observed in 1815, (as well as I recollect,) between Nazareit and Reiti. The highest lake fed by melted snows, in March, when I saw it, was bright blue. It discharged itself by a small stream into another, into which a number of large pines had been blown by a winter storm; or fallen from some other cause: in this lake its colour was blue green. In a third lake, in which there were not only pines and their branches, but likewise other 
decaying vegetable matter, it had a tint of faded grass green; and these changes had occurred in a space not much more than a mile in length. These observations I made in 1815; on returning to the same spot twelve years after, in August and September, I found the character of the lakes entirely changed. The pine wood washed into the second lake had disappeared; a large quantity of stones and gravel washed down by torrents, or detached by an avalanche, supplied their place: there was no perceptible difference of tint in the two upper lakes, but the lower one, where there was still some vegetable matter, seemed to possess a greener hue. The same principle will apply to the Scotch and Irish rivers, which, when they rise or issue from pure rocky sources, are blue, or bluish green; and when fed from peat bogs, or alluvial countries, yellow, or amber-coloured, or brown-even after they have deposited a part of their impuri- . ties in great lakes. Sometimes, though rarely, mineral impregnations give colour to water: small streams are sometimes green or 
yellow from ferruginous depositions. Calcareous matters seldom affect their colour, but often their transparency, when deposited, as is the case with the Velino at Terni, and the Anio at Tivoli; but I doubt if pure saline matters, which are in themselves white, ever change the tint of water.

OrN.-On what then does the tint of the ocean depend, which has itself given name to a colour?

HAL. - I think probably on vegetable matter, and perhaps, partially, on two elementary principles, iodine and brome, which it certainly contains, though these are possibly the results of decayed marine vegetables. These give a yellow tint when dissolved in minute portions in water, and this mixed with the blue of pure water would occasion sea green. I made many years ago, being on the Mer de Glace, an experiment on this subject, I threw a small quantity of iodine, a substance then recently discovered, into one of those deep blue basins of water which are so frequent on that glacier; and diffusing it as it dissolved with a-stick, I saw the water 
change first to sea green in colour, then to grass green, and lastly to yellowish green: I do not however, give this as a proof, but only as a fact favourable to my conjecture.

Poict.-It appears to me to confirm your view of the subject, that snow and ice, which are merely pure chrystalized water, are always blue when seen by transmitted light. I have often admired the deep azure in crevices in masses of snow in severe winters, and the same colour in the glaciers of Switzerland, particularly at the arch where the Arve issues, in the Valley of Chamouni. We thank you for your illustration.

HaL. - In return, I ask you for some further remarks on this grand waterfall. You said just now; you preferred the fall of the Velino for picturesque effect to any other waterfall you have seen; yet it is a small river compared even with the Traun, and nothing compared with the Gotha, the Rhine, or above all, the Glommen.

Poiet.-Size is merely comparative: I prefer the fall of the Velino, because its parts are in harmony. It displays all the 
force and power of the element, in its rapid and precipitous descent, and you feel that even man would be nothing in its waves, and would be dashed to pieces by its force. The whole scene is embraced at once by the eye, and the effect is almost as sublime as that of the Glommen, where the river is at least one hundred times_as large; for the Glommen falls, as it were, from a whole valley upon a mountain of granite, and unless where you see the giant pines of Norway, fifty or sixty feet in height, carried down by it and swimming in its whirlpools like straws, you have no idea of its magnitude and power: yet still, I think, considering it in all its relations, this is the most awful fall of water I have seen, as that of Velino is the most perfect and beautiful. I am not sure that I ought not to place the fall of the Gotha above that of the Rhine, both for variety of effect and beauty; and, I think, the river is quite as large, and the colour of the water quite as beautiful.

HaL. - But our horses are ready, and the time of separation arrives. I trust we shall 
all have a happy meeting in England in the winter. I have made you idlers at home and abroad, but I hope to some purpose; and, I.trust, you will confess the time bestowed upon angling has not been thrown away. The most important principle perhaps in life is to have a pursuit-a useful one if possible, and at all events an innocent one. And the scenes you have enjoyedthe contemplations to which they have led, and the exercise in which we have indulged, have, I am sure, been very salutary to the body, and, I hope, to the mind. I have always found a peculiar effect from this kind - of life; it has appeared to bring me back to early times and feelings, and to create again the hopes and happiness of youthful days.

Phys.-I felt something like what you described, and were I convinced that in the cultivation of the amusement, these feelings would increase, I would devote myself to it with passion; but, I fear, in my case this is impossible. Ah! could I recover any thing like that freshness of mind which I possessed at twenty-five, and which, like the dew of 
the morning, covered all objects and nourished all things that grew, and in which they were more beautiful even than in sunshine,-what would I not give! - All that I have gained in an active and not unprofitable life. How well I remember that delightful season, when full of power I sought for power in others; and power was sympathy, and sympathy power. When every voice seemed one of praise and love; when every flower had the bloom and odour of the rose, and every spray or plant seemed either the poet's laurel, or the civic oakwhich appeared to offer themselves to my ready and willing hands. But, alas! this cannot be; and even you cannot have two springs in life-though I have no doubt you have fishing days, in which the feelings of youth return, and that your autumn has a more vernal character than mine.

Poiet.-I do not think Halieus had ever any season except a perpetual and gentle spring; for the tones of his mind have been always so quiet, it has been so little scorched by sunshine, and so little shaken by winds, 
that, I think, it may be compared to that sempivernal climate fabled of the Hesperides, where the same trees produced at once buds, leaves, blossoms, and fruits.

- HaL. - Nay, my friends! spare me a little, spare my grey hairs. I have not perhaps abused my youth as much as some of my friends, but all things that you have known, I have known; and if I have not been so much scorched by the passions from which so many of my acquaintances have suffered, I owe it rather to the constant employment of a laborious profession, and to the exertions called for by the hopes, wants, and wishes of a rising family, than to any merits of my own, either moral or constitutional. For my health, I may thank my ancestors, after my God, and I have not squandered what was so bountifully given; and though I do not expect, like our arch patriarch Walton, to number ninety years and past, yet, I hope, as long as I can enjoy in a vernal day the warmth and heat of the sunbeams, still to haunt the streams-following the example of our late venerable friend, the 
President of the Royal Academy, in company with whom, when he was an octogenarian, I have thrown the fly, caught trout, and enjoyed a delightful day of angling and social amusement, in the shady green meadows by the bright clear streams of the Vandalis.

* Benjamin West.

THE, END. 
L O N D O N :

PRINTED RY C. ROWORTH, BELL YARD, TEMPLE BAR. 



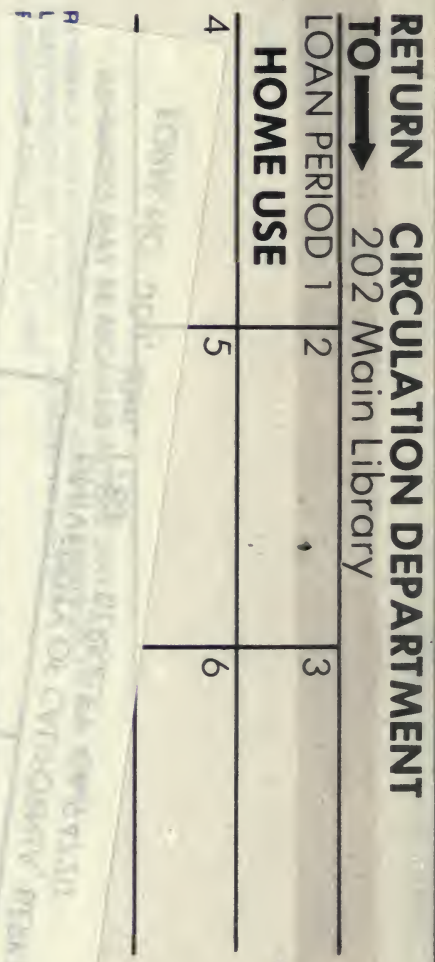




$$
86 \beta .29
$$

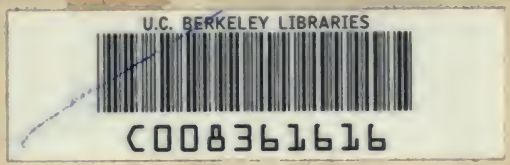




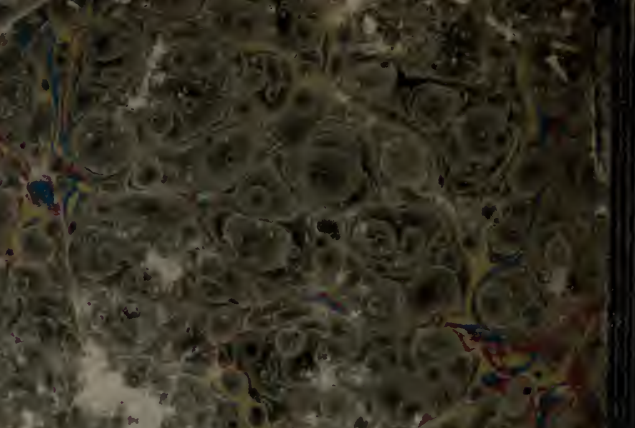

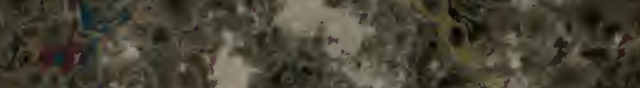

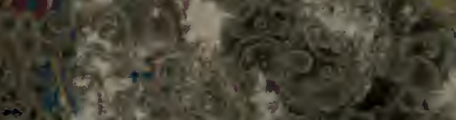

$\rightarrow 2.7$.

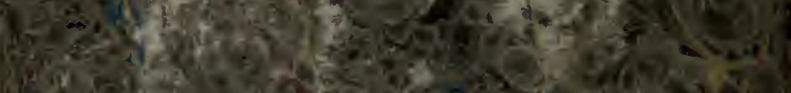

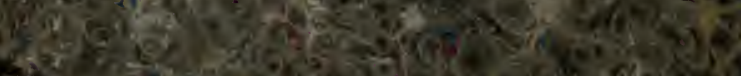

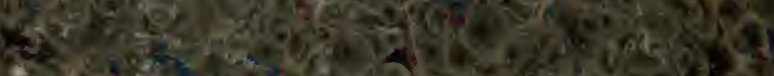

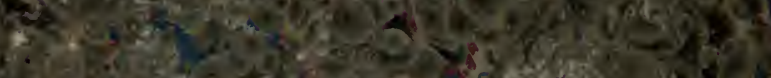

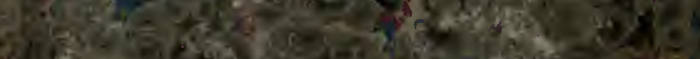

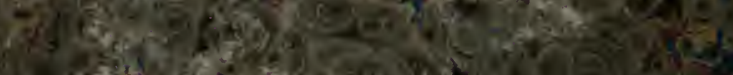

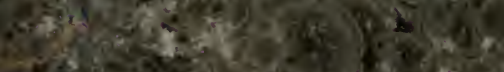

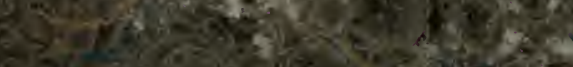

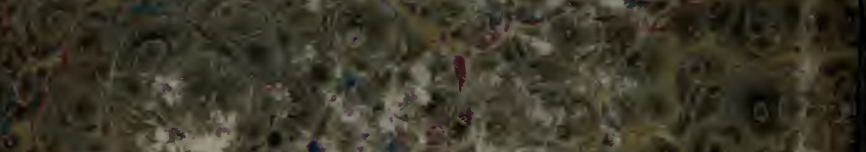

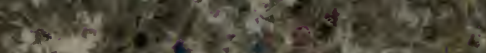

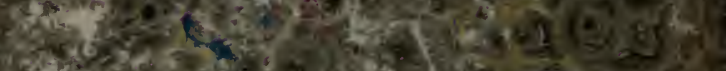

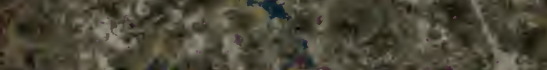

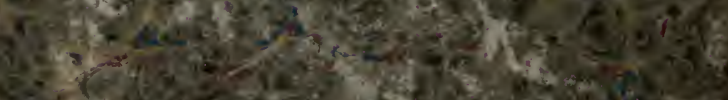

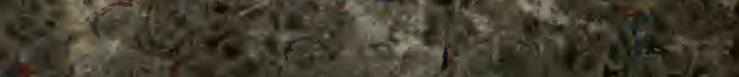

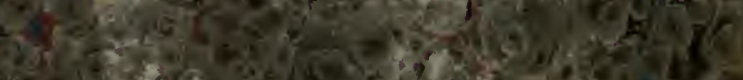

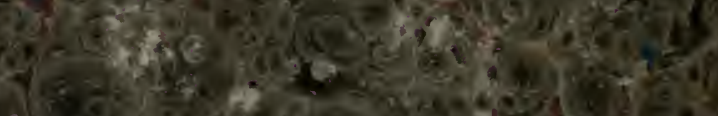

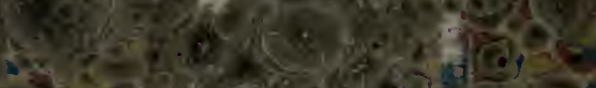

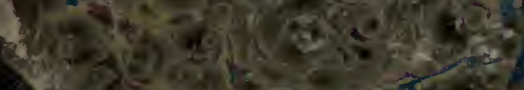

$$
\text { 2. }
$$

